\title{
Excavations of the New Kingdom Fortress in Jaffa, 2011-2014: Traces of Resistance to Egyptian Rule in Canaan
}

\author{
AARON A. BURKE, MARTIN PEILSTÖCKER, \\ AMY KAROLL, GEORGE A. PIERCE, KRISTER KOWALSKI, \\ NADIA BEN-MARZOUK, JACOB C. DAMM, ANDREW J. \\ DANIELSON, HEIDI D. FESSLER, BRETT KAUFMAN, \\ KRYSTAL V.L. PIERCE, FELIX HÖFLMAYER, BRIAN N. \\ DAMIATA, AND MICHAEL DEE
}

Open Access on AJA Online

Excavations of the Egyptian New Kingdom fortress in Jaffa (Tel Yafo, ancient Yapu), on the southern side of Tel Aviv, were renewed by the Jaffa Cultural Heritage Project from 2011 to 2014. This work is an outgrowth of the project's reappraisal of Jacob Kaplan's excavations in the Ramesses Gate area from 1955 to 1962. As the Egyptian fortress in Jaffa is the only one excavated in Canaan, its archaeological record provides a unique perspective on resistance to Egyptian rule from ca. 1460 to 1125 B.C.E., but especially during the second half of the 12th century B.C.E., when Jaffa was twice destroyed. Radiocarbon dates from these two destructions are presented, and it is suggested that they offer the clearest basis thus far for proposing ca. 1125 B.C.E. as a terminus post quem for the end of Egyptian rule in Canaan. The archaeological evidence, taken together with textual sources, yields a picture of local resistance to the Egyptian military presence in Jaffa likely originating in Canaanite centers located throughout the coastal plain. ${ }^{1}$

\section{INTRODUCTION}

Situated on the central coast of Israel, on the southern side of Tel Aviv, and $60 \mathrm{~km}$ to the northwest of Jerusalem (fig. 1), Jaffa's antiquity and importance

American Journal of Archaeology

Volume 121, Number 1

January 2017

Pages 85-133

DOI: $10.3764 /$ aja.121.1.0085

www.ajaonline.org

\footnotetext{
${ }^{1}$ We would like to thank Gideon Avni, who served as the Director of Excavations and Surveys during the project's first five years and was instrumental in providing support and advice leading to the project's establishment. We likewise extend our gratitude to the late Shuka Dorfman, general director of the Israel Antiquities Authority, for his support and vision for the project, and to Charles Stanish, director of the Cotsen Institute of Archaeology at the University of California, Los Angeles (UCLA), for his enduring support of the project. The directors are also grateful to the Cotsen Institute of Archaeology Press for its support of the project's publication efforts. We thank Y. Klein, D. Gidoni, and N. Meirovitz of the Old Jaffa Development Corporation for permission to excavate, logistical assistance, and facilities access. Figures are by the authors unless otherwise noted. Registration numbers referred to in text are designated as follows: MHA (i.e., Museum Haaretz) numbers originated with object registry cards from the Jaffa Museum for finds from excavations by the Kaplans in Jaffa, and the sequence was continued during the Jaffa Cultural Heritage Project's efforts to publish these excavations; JCHP numbers were assigned to finds from the 2011-2014 excavations; TAU numbers were assigned during Tel Aviv University excavations in 1997 and 1999.
} 


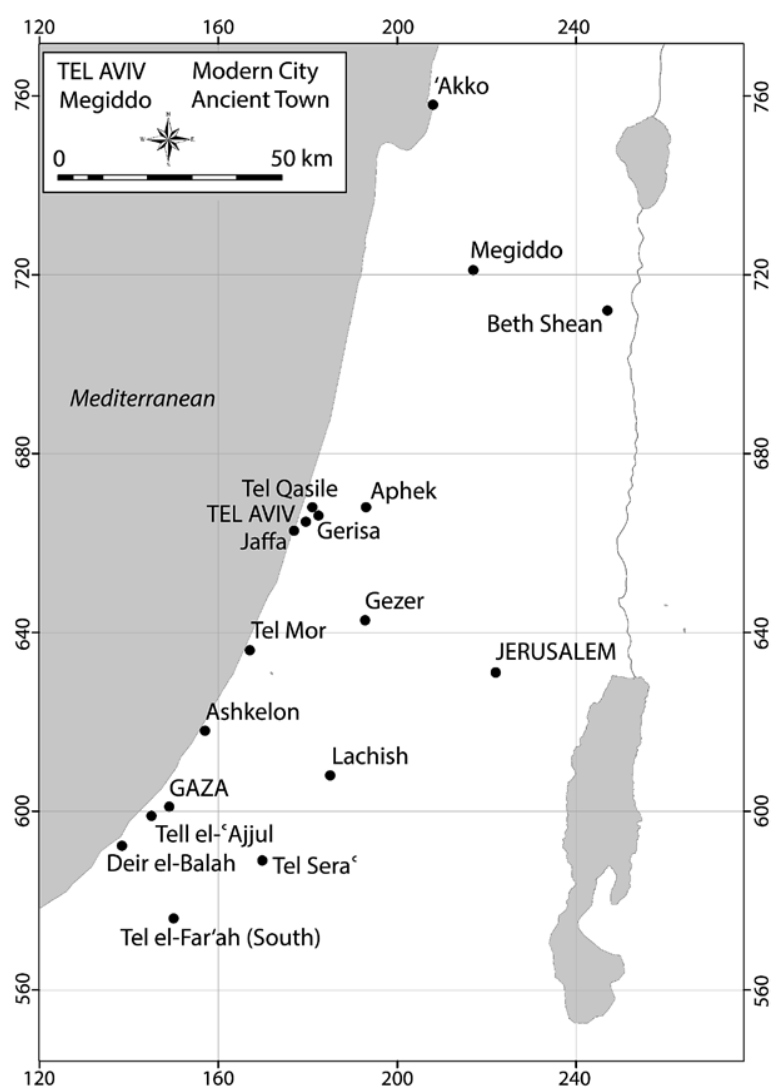

FIG. 1. Location of Jaffa and southern Levantine sites mentioned in the text (drawing by K. Kowalski).

as a Mediterranean port was well recognized before excavations began at the site in the mid 20th century. Biblical references relate Jaffa's significance as a port, ${ }^{2}$ and sources such as Josephus document Jaffa's limitations as a harbor by the Classical period. ${ }^{3}$ It was during the 1950s, however, that the site's importance for understanding New Kingdom imperial control of Canaan became paramount, particularly in its role as both an Egyptian fortress and a probable harbor. This was the result of the exposure, by Jacob Kaplan, of extensive archaeological evidence for an Egyptian military

\footnotetext{
${ }^{2}$ References in the Hebrew Bible to Jaffa include the story of the prophet Jonah's sailing from Jaffa to Tarshish (Jon. 1:3) and references to the transport of cedars from Lebanon in connection with the construction of the first (2 Chron. 2:16 [Heb. 2:15]) and second (Ezra 3:7) temples in Jerusalem during the Iron Age and Persian period, respectively.

${ }^{3}$ For a recent review of Jaffa in the Classical period and references in Josephus, see Notley 2011. For the earlier periods, see Burke 2011a.
}

presence in Jaffa spanning most of the Late Bronze Age (mid 15th to late 12th century B.C.E.; table 1). Yet inadequate publication of these findings has made it impossible to fully evaluate this evidence or to place Jaffa alongside other, more recently published sites in Canaan that collectively document a wide range of interactions between Egypt and Canaan's inhabitants during the course of the New Kingdom. ${ }^{4}$

Research on New Kingdom Egypt in Canaan over the past two decades has focused principally on social interactions between Egyptians and Canaanites, often seeking to qualify elements of the cultural record as evidence either of direct rule by Egypt or of the emulation of Egyptian elites by Canaanites, if not both. ${ }^{5}$ Lost among these discussions is any evidence for the effects of violent resistance to Egyptian rule by the region's inhabitants, which according to New Kingdom historical sources occurred periodically from at least the Battle of Megiddo (ca. 1460 B.C.E.) to the demise of Egyptian rule in the late 12th century B.C.E. (ca. 1130 B.C.E.). The most significant data for these interactions was obtained prior to 2006, when final excavation reports for Egyptian settlements at Tel Mor, Aphek, Beth Shean, and Deir el-Balah began to appear. ${ }^{6}$ These reports were followed by preliminary reports for subsequent work at Ashkelon, Tell el-'Ajjul, Qubur al-Walayda, and other, earlier excavations. ${ }^{7}$ The importance of documenting violence in Egyptian-Canaanite interactions is underscored by the fact that Jaffa was both an Egyptian port and the largest known Egyptian fortress in Canaan during the New Kingdom, two roles that are

\footnotetext{
${ }^{4}$ Kaplan (1972) published a brief review article in which he addressed the Egyptian gate complex, but this was prior to an analysis of most of the Egyptian artifacts and ceramics. The 1972 article was a revised and expanded version of a short book that had previously appeared in Hebrew (Kaplan 1959). Neither of these reviews permits an evaluation of the criteria Kaplan employed to assign dates to the "levels" he identified.

${ }^{5}$ Hasel 1998; Higginbotham 2000; Killebrew 2004, 2005; Martin 2011.

${ }^{6}$ Mazar 2006, 2012; Barako 2007; Mazar and Mullins 2007; Gadot and Yadin 2009; Panitz-Cohen and Mazar 2009; Dothan and Brandl 2010a, 2010b.

${ }^{7}$ Fischer and Sadeq 2008; Martin 2008, 2009; Lehmann et al. 2009, 2010. Unfortunately, final reports remain unavailable for excavations conducted at a number of Egyptian fortresses in the northern Sinai (Oren 1987, 2006), at Tel Sera' (Oren 1993, 1997), and at Tell es-Sa idiyeh (Tubb 1988, 1990; Tubb and Dorrell 1991, 1993, 1994; Tubb et al. 1996, 1997). See also Pritchard's (1980) report on the cemetery of Tell es-Sa 'idiyeh.
} 
TABLE 1. Periodization of the Late Bronze Age in the southern Levant (New Kingdom Egyptian chronology after Kitchen 2000a).

\begin{tabular}{lcc}
\hline Period & Egyptian Chronology and Key Reigns & Approximate Dates B.C.E. \\
\hline LB IA & early 18th Dynasty & $1550-1460$ \\
LB IB & mid 18th Dynasty & $1460-1400$ \\
& Thutmose III (ca. 1478-1424) & \\
LB IIA & Amenhotep II (ca. 1424-1398) & $1400-1300$ \\
late 18th Dynasty (Amarna period) & \\
LB IIB & Amenhotep III (ca. 1388-1350) & \\
& Akhenaten (ca. 1350-1334) & \\
& 19th Dynasty (Ramesside period) & \\
LB III & Ramesses II (ca. 1266-1200) & $1175-1065$ \\
& Merneptah (ca. 1200-1191) & \\
& 20th Dynasty (Ramesside period) & \\
& Ramesses III (ca. 1173-1142) & \\
& Ramesses IV (ca. 1142-1136) & \\
& Ramesses VI (ca. 1132-1125)
\end{tabular}

not yet sufficiently documented within the hierarchy of Egyptian settlements identified in Canaan to date. Some sites, such as Tel Mor, appear to have been very small fortified enclaves (e.g., roadside stations), while others, such as Beth Shean, appear to have largely functioned as administrative centers, although they may also have hosted Egyptian garrisons. ${ }^{8}$ Still other sites, such as Tell el-'Ajjul, were excavated too early and published too poorly to provide the chronological and spatial resolution necessary to evaluate evidence for resistance. ${ }^{9}$ Jaffa's archaeological record, representing a large fortress and strategic harbor, is therefore of crucial importance to an analysis of New Kingdom empire and administration in Canaan. It is also well suited to an intensive investigation of the role played by violent resistance to Egyptian rule, owing to evidence for several destructions from the mid 15 th century B.C.E. to the end of the 12 th century B.C.E.

More than 60 years after the start of Kaplan's excavations in Jaffa, the publication and excavation efforts of the Jaffa Cultural Heritage Project (JCHP) have shed new light on Jaffa's Late Bronze Age history. In 2007,

\footnotetext{
${ }^{8}$ Mazar 2011.

${ }^{9}$ Tufnell and Kempinski 1993, 53.
}

Aaron A. Burke (University of California, Los Angeles) and Martin Peilstöcker (Johannes-Gutenberg Universität, Mainz) established the JCHP with the overarching goal to facilitate long-term research of Jaffa's cultural heritage through the integration of research and salvage excavations, cultural and historical studies, and multidisciplinary scientific approaches. ${ }^{10}$ Central to this objective was the renewal of excavations on the mound of ancient Jaffa, properly referred to as Tel Yafo. ${ }^{11}$ As part of the initial phase of the project, the Kaplan Excavations Publication Initiative was conceived to provide an in-depth analysis of the unpublished research by the site's most prolific excavator, Jacob Kaplan, who conducted work on behalf of the municipality of Tel

\footnotetext{
${ }^{10}$ For an overview of the project's design and general objectives, see Burke and Peilstöcker 2011.

${ }^{11}$ The Arabic term "tell" or Hebrew "tel" is usually employed for abandoned mounds representing destroyed ancient cities. The term is inappropriate for Jaffa before 1936 but can be employed today to distinguish the mound from the lower city, which itself experienced various phases of growth and contraction. It was not until military efforts as part of "Operation Anchor" in 1936, when the British Mandate government sought to widen the streets on the highest part of the old city of Jaffa, that any open space existed atop the mound (Strul 2011, 41).
} 
Aviv-Jaffa and the Israel Department of Antiquities and Museums from 1955 to 1974 (fig. 2). ${ }^{12}$ His work resulted, however, only in a series of very short preliminary reports. ${ }^{13}$ The present effort was made possible by the deposit of the Kaplan legacy archive (the documentation of Kaplan's excavations at more than 30 sites) with the Israel Antiquities Authority (IAA) in 1999. ${ }^{14}$

Our initial assessment of Kaplan's excavation records indicated that the resumption of research excavations was essential to accurately publishing the earlier excavations, a large part of which concerned the Egyptian New Kingdom fortress. In fact, significant data from many periods of occupation are inadequately represented despite the ample archaeological finds that are known to have originated from the site since the late $1940 \mathrm{~s}^{15}$ Part of this problem may stem from the challenges inherent in sustaining archaeological research in Jaffa, as evidenced by the fact that no research institution carried out more than two seasons of fieldwork at the site, with the most recent attempt made by Tel Aviv University ending in $1999 .{ }^{16}$

\footnotetext{
${ }^{12}$ For an overview of the initiative, see Burke $2011 \mathrm{~b}$. This publication project has been supported since 2008 by the Shelby White and Leon Levy Program for Archaeological Publications at Harvard University.

${ }^{13}$ Kaplan 1956, 1960, 1961, 1962, 1964, 1966, 1970, 1971, 1974; Kaplan and Kaplan 1975. Kaplan's abrupt removal from his position as municipal archaeologist of Tel Aviv-Jaffa in 1974 followed a change in Tel Aviv's mayors and restricted his access to the excavated finds necessary for final publication.

${ }^{14}$ For a complete list of excavations by Jacob Kaplan and Haya Ritter-Kaplan, see Bar-Nathan 2002. In 2007, the JCHP's staffjoined ongoing IAA salvage excavations in the Ganor Compound (see fig. 2) as part of a pilot excavation project (Peilstöcker and Burke 2011), which permitted staff the opportunity to conduct a preliminary assessment of the Kaplan legacy. This assessment revealed the potential for reconstructing archaeological contexts from Kaplan's records. See Keimer's (2011) preliminary analysis of Areas B and D. This led to the first excavations on the tell from 2008 to 2009 in Area C in Qedumim Square. In these excavations, Roman and Hellenistic remains were primarily uncovered in association with an in-filled monumental ashlar building dated to the Early Hellenistic period. For preliminary reports, see Burke and Peilstöcker 2009; Burke et al.2014. For additional summaries of early work, see Burke and Burke 2008; Burke 2009, 2011c, 2012; Peilstöcker and Burke 2011. These new excavations revealed the viability of the project's organizational structure and highlighted the logistical challenges facing a sustainable approach to archaeological research in an urban environment such as Jaffa.

${ }^{15}$ For an overview of previous archaeological work, see Peilstöcker 2011b.

${ }^{16}$ Herzog 2008; see also Sweeney 2003. While excavations
}

Each effort, including our own, has been beset by the challenges of conducting archaeological research in an urban environment, a perception of a dearth of findings for Iron Age "biblical" archaeology, and the burden of coordinating interpretations with earlier, unpublished excavations at the site.

Excavations of the Egyptian fortress were renewed by the JCHP in 2011, despite significant obstacles. These excavations provide new insights into recurring resistance to Egyptian rule through an archaeological sequence spanning Egypt's imperial history in Canaan, ca. 1460 to 1125 B.C.E. ${ }^{17}$ A brief introduction to Jaffa during the Bronze Age is provided here to set the context for its role within Egypt's New Kingdom empire in Canaan. Previous excavations that form the basis for archaeological reconstructions of Jaffa's Egyptian occupation are reviewed and followed by a preliminary report on the current project's findings within the Ramesses Gate area from 2011 to 2014 . The work concludes with our analysis and interpretation of Jaffa's fortress during the New Kingdom, with attention focused on the evidence for two radiocarbon-dated destructions of Jaffa's fortress during the second half of 12 th century B.C.E. and their implications for understanding the decline of Egyptian rule in Canaan.

\section{BRONZE AGE JAFFA: FROM CANAANITE PORT TO EGYPTIAN FORTRESS}

Excavations of Middle and Late Bronze Age cemeteries around Jaffa since the 1950s have played an

were conducted in the Ramesses Gate area in 1997, full-scale excavations in both the Ramesses Gate and Lion Temple areas occurred only in 1999. Because final reports for these excavations remain unpublished, and since preliminary findings adhere closely to the original phasing (Kaplan and Ritter-Kaplan 1993), it has not been possible thus far to more fully incorporate this work into the reassessment of Kaplan's excavation records or the analysis of the renewed excavations by the JCHP.

${ }^{17}$ As clarified later in this article, these dates approximate the duration of Egyptian control of Jaffa, which began after the Battle of Megiddo (ca. 1460 B.C.E.) and ended with the radiocarbondated destruction of the final fortress, ca. 1125 B.C.E. Regnal dates for Egyptian pharaohs and New Kingdom dynasties follow Kitchen 2000a. As Kitchen (2000a, 44) notes, the traditionally high date of 1504 B.C.E. for the accession of Thutmose III requires an insertion of at least "a blank 25 years" into the 18th Dynasty, which we agree seems unwarranted. The revised dates have been adopted in several recent syntheses of the Late Bronze Age in the southern Levant (e.g., Fischer 2014; PanitzCohen 2014). 


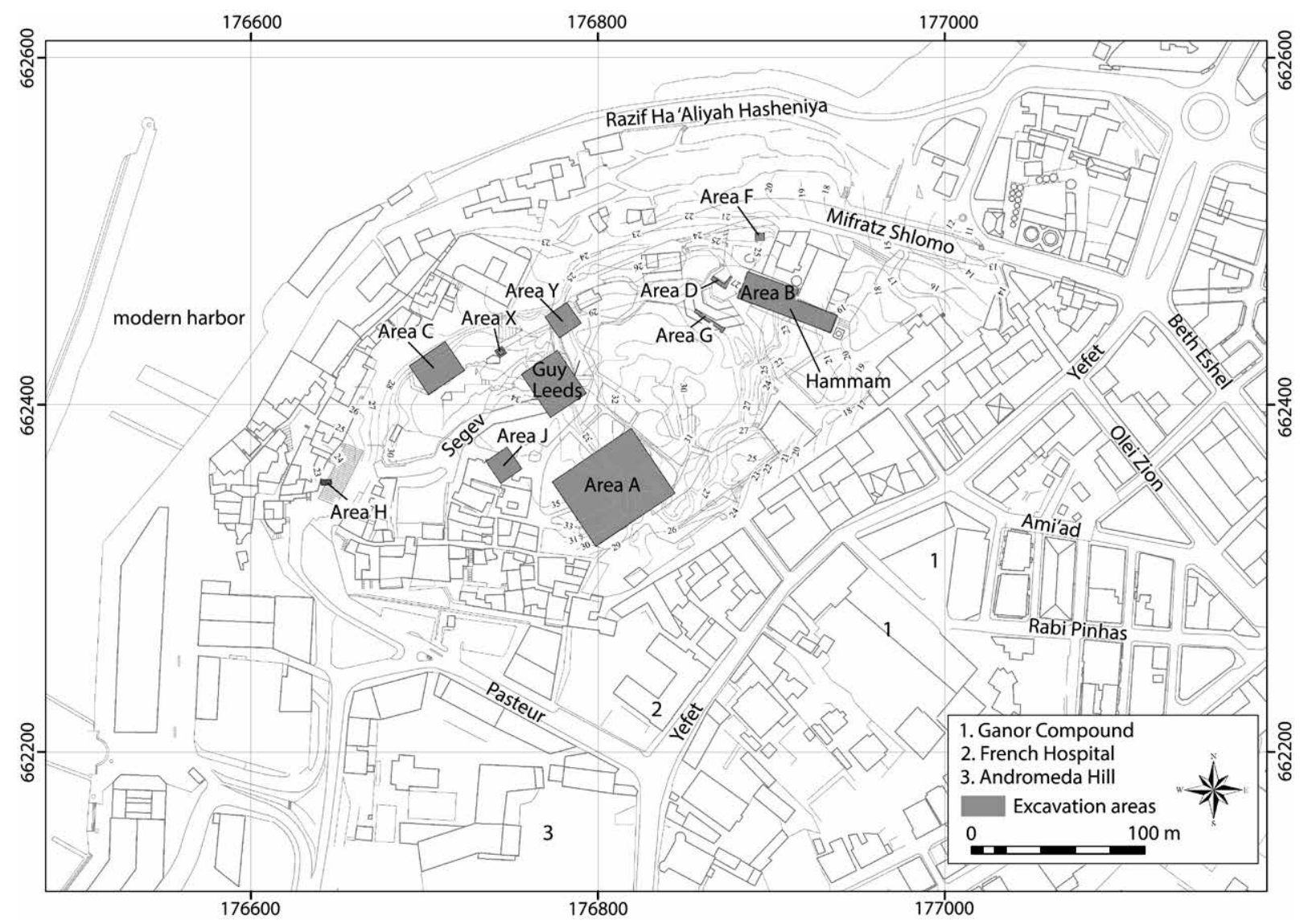

FIG. 2. Contour plan showing the locations of excavation areas on Tel Yafo prior to work by the JCHP, as well as extant structures. All areas were originally excavated by Kaplan except for the one labeled "Guy/Leeds” (drawing by K. Kowalski).

important role both in identifying its population prior to Egyptian rule as Canaanite ${ }^{18}$ and in identifying the limits of the Bronze Age settlement. During this period, Jaffa's settlement appears to have been restricted to the roughly 2 ha tell (see fig. 2 ), as no substantive settlement has been detected along the slopes of the mound, despite extensive salvage excavations in recent years. ${ }^{19}$

\footnotetext{
${ }^{18}$ Canaanites, we acknowledge, include a wide range of socioeconomic, political, and military agents who were later opposed to Egyptian rule in Canaan but who nonetheless shared a material culture during the Middle and Late Bronze Ages that features the greatest number of common attributes across the geographic region known as Canaan.

${ }^{19}$ For salvage excavations, see Peilstöcker 2011b. Although it appears there are no Bronze Age settlement remains below Jaffa's mound, it is noteworthy that kurkar sandstone has been observed overlying earlier occupational layers, having formed during interludes in the settlement of the lower town, a process also attested at other sites along Israel's coast. This happened when sand dunes encroached on abandoned areas of settlement and the high water table in the area permitted a new stone layer
}

Settlement appears to have been confined to the area within the town's Middle Bronze Age fortifications until the end of the Late Bronze Age. ${ }^{20}$ The mound was ringed by a cemetery employed continuously from the Middle Bronze Age through the Late Bronze Age, as is typical of contemporaneous settlements in Canaan (e.g., Megiddo, Beth Shean). A Late Bronze (LB) I cemetery was identified on the eastern slopes of the mound in an area known as the Ganor Compound, about $200 \mathrm{~m}$ to the east of the gate. ${ }^{21}$ On Jaffa's southern slope and within the grounds of the French Hospital, part of another Late Bronze Age cemetery was exposed, ${ }^{22}$ which probably extended along the kurkar sandstone ridge

to begin to consolidate. The problem is sufficiently significant that to guarantee that true bedrock has been actually reached the kurkar must be probed.

${ }^{20}$ Kaplan's encounter with the earthen rampart is discussed later in this article.

${ }^{21}$ Peilstöcker 2011a.

${ }^{22}$ Re'em 2010. 
southward to the Andromeda Hill housing project, where more Late Bronze tombs were encountered. ${ }^{23}$ Traditional Canaanite burials persisted throughout the Late Bronze Age with, surprisingly, no evidence for Egyptian-style burials after the start of Egyptian rule in Jaffa.

At the start of the Late Bronze Age (LB IA), Jaffa remained beyond the reach of the ad hoc campaigns of early 18th-Dynasty pharaohs, which appear to have been concentrated in the coastal plain to the south of Jaffa, with occasional raids made into the northern Levant from the Syrian coast. ${ }^{24}$ Jaffa's first historical mention, as Yapu, occurs among a list of towns that were conquered in connection with the first campaign of Thutmose III (ca. 1478-1424 B.C.E.), which also included Aphek, Gerisa, and Michal in the central coastal plain. ${ }^{25}$ It is unknown, however, whether the towns listed by Thutmose III were destroyed or whether those listed as conquered were included as a result of their participation in the defeated Canaanite coalition at Megiddo. ${ }^{26}$ No historical or archaeological evidence exists to support Jaffa's destruction at the end of the LB IA as part of an Egyptian conquest, and therefore the nature of its transition from Canaanite to Egyptian rule remains unclear. ${ }^{27}$

Jaffa is also mentioned during the 14th century B.C.E. in the Amarna Letters and again during the 13th century B.C.E. in a letter from Ugarit to the Egyptian governor at the agricultural estate at Aphek. ${ }^{28}$ From

\footnotetext{
${ }^{23}$ Ayash and Buchennino 1999.

${ }^{24}$ Burke 2010.

${ }^{25}$ For references to Thutmose III's list, see Simons 1937, 117; see also Pritchard 1969, 242 n. 62.

${ }^{26}$ For a discussion of these destructions, see Burke 2008, 101.

${ }^{27}$ See Weinstein (1991) on the issues surrounding the attribution of the destruction of sites in Canaan during the transition between the Middle and Late Bronze Ages. There is no basis in the archaeological record from Jaffa to support Kaplan's $(1972,78)$ identification of the context of the literary Tale of the Capture of Jaffa (P. Harris 500) as illustrative of Jaffa's conquest by Thutmose III.

${ }^{28}$ Moran (1992) suggests that references to Yapu in the Amarna Letters constitute three different cities featuring the same name (EA 138, lines 6, 84; 294, line 20; 296, line 33; 365, line 26), but see discussion in Burke 2011a, 69. Yapu was also likely Jaffa's name during the Middle Bronze Age (Burke 2011a, 66). For the Aphek governor's letter, see Horowitz et al. 2006, 35-8, cat. no. Aphek 7. For the characterization of Aphek as an agricultural estate in this period, see Gadot 2010. A fragmentary letter from Gezer may date to the Late Bronze Age as well (Horowitz et al. 2006, 53-5, cat. no. Gezer 2).
}

these references it appears that one of Jaffa's main roles was its strategic function as a granary for the Egyptian army, storing grain from Egyptian estates throughout the coastal plain..$^{29}$ This was in addition to its continued role as a harbor on the coast of Canaan. Although its maritime capacity is not elucidated by Egyptian sources, it can be inferred from Jaffa's seaside location and the probability that at this time Jaffa was situated at the mouth of the Ayalon River. ${ }^{30}$ To date, Jaffa remains the primary Egyptian port north of Gaza and south of Byblos on the southern Levantine coast. Thutmose III may have designated Jaffa an htm-base along with sites such as 'Akko, Yarimuta, Byblos, and Ullaza. Such ports "monitored the passage of people and goods" as well as communications, permitted the collection of tariffs and the hunting of fugitives, and served as storage depots. ${ }^{31}$

\section{PREVIOUS EXCAVATIONS IN THE RAMESSES}

\section{GATE, 1955-1999}

Despite their usefulness, the limited textual references to Jaffa under Egyptian rule leave unanswered questions that can be addressed only through research excavations. These began under Kaplan in 1955 in Area A on the southeastern side of the mound (see fig. 2), where in 1956 he encountered the first evidence of the Egyptian fortress. ${ }^{32}$ The excavations in this area had been made possible as a result of the British military's "Operation Anchor" in 1936 that led to the abandonment of much of Jaffa's old city, ${ }^{33}$ and Area A remains available for excavations today as a result of Kaplan's efforts to limit construction on Jaffa's mound..$^{34}$ Area A consists of two subareas, each of which was identified by Kaplan according to its association with a major feature of the Egyptian settlement (fig. 3). Excavations from 1955 to 1962 in the so-called Ramesses Gate, which is located in the eastern half of Area A, revealed a Late Bronze Age gateway to the Egyptian fortress

\footnotetext{
${ }^{29}$ Burke 2011a, 69.

${ }^{30}$ For this suggestion, see Raban 1985, 27.

${ }^{31}$ Morris 2005, 138-39 n. 90, 804-9. This would put Jaffa in a distinctly different situation vis-à-vis Beth Shean and Sharuhen (Tell el-'Ajjul), other important Egyptian administrative centers with extensive evidence of an early Egyptian garrison, which, however, are identified in Egyptian as dmiw or simply as settlements (Morris 2005, 815-17).

${ }^{32}$ For a concise overview of Kaplan's research in Jaffa, see Kaplan and Ritter-Kaplan 1993.

${ }^{33}$ For a discussion of "Operation Anchor," see Gavish 2013.

${ }^{34}$ Ajami 2011.
} 


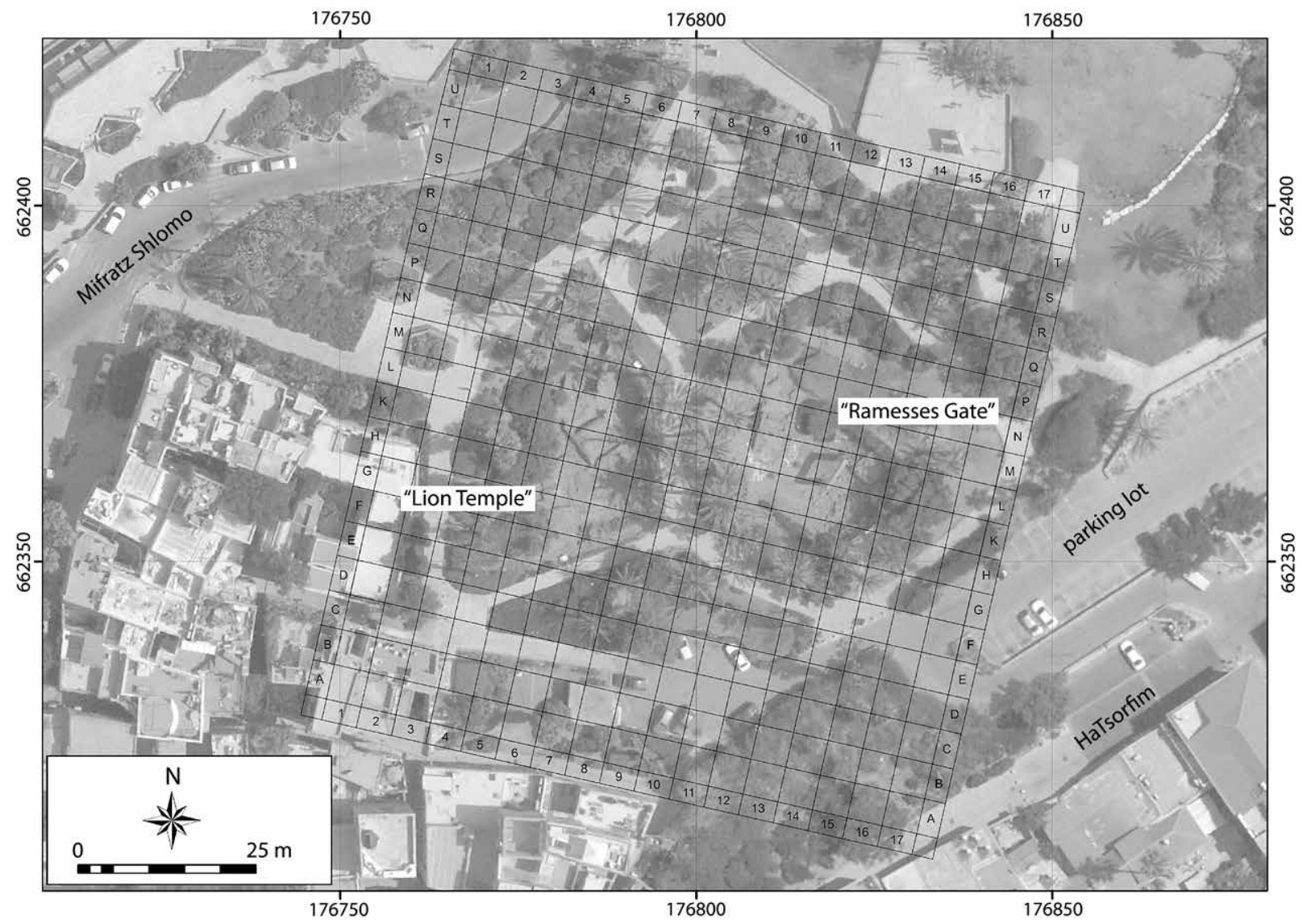

FIG. 3. Aerial view of Area A and area on Tel Yafo north and west toward Mifratz Shlomo Street, showing the location of the two excavation areas, the Ramesses Gate on the east and the Lion Temple on the west, both of which are bounded by sidewalks. The grid system is that of the JCHP from 2011 on and was intended to encompass areas beyond the boundaries of Kaplan's Area A (drawing by K. Kowalski).

as well as the remains of a food-preparation area. The Late Bronze Age levels within the fortress centered on a small building to the west of the gate identified as the Lion Temple, which was excavated from 1970 to 1974 and gave its name to that area. ${ }^{35}$ Within the Ramesses Gate, Kaplan identified a stratigraphic sequence spanning from the second half of the Middle Bronze Age to the Hellenistic period (table 2). ${ }^{36}$ The sequence as presented must be regarded as preliminary, however, since

\footnotetext{
${ }^{35}$ Kaplan and Ritter-Kaplan 1993. Tel Aviv University excavated here in 1999 (Herzog 2008), and the JCHP renewed excavations of the Lion Temple area in 2014.

${ }^{36}$ Kaplan and Ritter-Kaplan 1993, 656-57. No effort was made to include occupational levels following the Hellenistic period in this sequence, despite the evidence for Islamic, Crusader, Mamluk, and Ottoman remains, as evident from unpublished records.
}

a final report was never published and but a few vessels appear among a handful of published photographs with limited details concerning their contexts. ${ }^{37}$ What follows is therefore a synthesis of Bronze Age remains from excavations in the Ramesses Gate based on Kaplan's published preliminary reports, the preliminary report of Herzog's excavations (which did not alter the original phasing), and analysis of Kaplan's records and excavated finds resulting from the current project's efforts since 2007. Although the archaeological sequence (prefixed "RG-") resulting from the renewed excavations in this area is discussed in the following section,

\footnotetext{
${ }^{37}$ Although the terms "stratum" and "level" (cf. Kaplan and Ritter-Kaplan 1993) were both used by Kaplan in different preliminary reports, the term "level" is employed in this work to identify Kaplan's stratigraphic assignments.
} 
TABLE 2. Area A, Ramesses Gate levels, periods, dates, and key findings according to Kaplan and Ritter-Kaplan 1993.

\begin{tabular}{llll}
\hline Level & Period & Dates B.C.E. & Key Findings \\
\hline IA & Hasmonean & $167-63$ & \\
IB & Early Hellenistic & $332-167$ & \\
II & Late Persian & $550-332$ & "Sidonian” Wall (W.3) \\
IIIA & Iron II & $1000-550$ & stone floor (glacis?) \\
IIIB & Iron IB & 11 th century & Philistine sherds from pits (e.g., L.9 [L.307]) \\
Gap & Iron IA & 12 th century & no settlement \\
IVA & LB III & $1250-1200$ & $\begin{array}{l}\text { destruction by fire; bronze gate hinge; Ramesses II frag- } \\
\text { ments in secondary contexts }\end{array}$ \\
IVB & LB IIB & $1300-1250$ & gate of Ramesses II; destruction by fire \\
V & LB IIA & $1400-1300$ & $\begin{array}{l}\text { small silo; "14th cent." sherds } \\
\text { VI late }\end{array}$ \\
LB IB & $1460-1400$ & $\begin{array}{l}\text { Egyptian mid 18th-Dynasty ceramic assemblage identi- } \\
\text { fied as kitchen }\end{array}$ \\
VI early & LB IA & $1550-1460$ & Cypriot Bichrome Wheelmade Ware \\
VII & MB IIC & $1650-1550$ & mudbrick fortification walls on earthen rampart \\
VIII & MB IIB & pre-1650 & earthen rampart construction? \\
\hline
\end{tabular}

Note: Italics represent clarifications to Kaplan's original phasing resulting from the JCHP's reassessment of the ceramic assemblage.

${ }^{a}$ Kaplan and Ritter-Kaplan 1993, 656-57.

correlations with Kaplan's levels are provided in figure captions in this section for ease of reference.

\section{Levels VIII-VII: Middle Bronze Age}

Kaplan's excavations in the Ramesses Gate provide limited insight concerning Jaffa before the Late Bronze Age. ${ }^{38}$ Kaplan claimed that levels VIII and VII in Area A consisted of traces of an earthen rampart associated with the town's defenses during Middle Bronze (MB) II (ca. 1800-1600 B.C.E.). ${ }^{39}$ While this could not be corroborated during the most recent excavations within the Ramesses Gate, an earthen rampart of likely Middle Bronze Age date was identified on the northern side of Jaffa in Area D (see fig. 2) ${ }^{40}$ the inner surface of which was encountered during the JCHP's

\footnotetext{
${ }^{38}$ Ceramic sherds originating from the Early Bronze I (ca. 3700-3100 B.C.E.) and possibly Late Chalcolithic settlement were identified during Tel Aviv University's excavations in the gate area (Gophna 2002, 419 n. 1). Similar sherds have also been identified among the materials from Kaplan's excavations in the Ramesses Gate area during the JCHP's efforts to prepare these materials for publication (Yitzhak Paz, pers. comm. 2012).

${ }^{39}$ Kaplan and Ritter-Kaplan 1993, 657.

${ }^{40}$ Kaplan 1961, 192; Keimer 2011.
}

2014 excavations in the Lion Temple. Herzog also suggested the existence of a Middle Bronze Age gate of the six-pier type in the Ramesses Gate area, ${ }^{41}$ but the elements identified with this supposed structure all belong to the Late Bronze Age, as determined during the JCHP's excavations.

\section{Level VI: LB I}

Kaplan encountered LB I remains that he ascribed to level VI, but he did not adequately distinguish these remains from level V, which he dated to LB IIA. Furthermore, he did not subdivide LB I remains into LB IA and LB IB assemblages. While LB IA remains at sites in the southern Levant often include Cypriot Bichrome Wheelmade Ware, LB IB is marked not only by its absence but also by the appearance of mid 18thDynasty ceramics. ${ }^{42}$ Instead, within a sounding excavated in 1958 inside the fortress to the south of the gate complex, Kaplan identified "four building phases ... resting on buildings of the MB II" as Late Bronze

\footnotetext{
${ }^{41}$ Herzog 2008, 1791; see also 1986, 74-5.

${ }^{42}$ Mazar 1990, 259-61; Martin 2011, 243-45.
} 
Age phases representing the 15th and 14th centuries B.C.E..$^{43}$ Kaplan notes only that the ceramics recovered from this sounding included "bichrome ware, Cypriot 'base-ring' I ware, and a number of complete vessels of Egyptian type." ${ }^{4}$ The presence of Cypriot Bichrome Wheelmade Ware, however, suggests an LB IA, if not a transitional MB IIC/LB IA, context among a range of wares representing the periods from at least LB IA to LB IIA.45

A review of these contexts confirms that the Cypriot Bichrome Wheelmade Ware from the deep sounding to the south of the gate originated from the lowest Late Bronze stratum, which we therefore identify as an LB IA context and designate as level VI early. ${ }^{46}$ Although Kaplan makes no reference to evidence for an LB IA destruction within the 1958 sounding to the south of the gate ${ }^{47}$ he suggests that Jaffa's Canaanite settlement was destroyed by the Egyptians on the basis of a "single locus of vessels ... found among a heap of burnt debris" dated to LB IA, which was evidently excavated to the north of the gate but inside the line of the fortification wall. ${ }^{48}$ However, because this context (L.300), which was identified by the JCHP, is actually a badly disturbed infant burial assemblage-including a rattle and a locally produced, bichrome-decorated cup that can be dated to LB IA (fig. 4$)^{49}$-it does not provide evidence of a destruction. Thus, in neither location where Kaplan encountered LB IA remains has evidence surfaced to support the identification

\footnotetext{
${ }^{43}$ Kaplan 1960; Kaplan and Ritter-Kaplan 1993, 656-57.

${ }^{44}$ Kaplan 1960, 122.

${ }^{45}$ For a previous study of Jaffa's Cypriot Bichrome assemblage, see Epstein 1966, 14, 16. No tests have been run on Jaffa's Bichrome Wheelmade Ware assemblage to determine its locus of production.

${ }^{46}$ As noted in table 2, italics represent clarifications to Kaplan's original phasing resulting from the JCHP's reassessment of the ceramic assemblage.

${ }^{47}$ Kaplan 1960, 122.

${ }^{48}$ Kaplan 1972, 78.

${ }^{49}$ In the preliminary reports for Jaffa, only a limited number of loci are ever discussed, and those that are discussed are never identified by number. Loci lists were not compiled for each level, so by necessity this has been one of the major undertakings of the publication project. Because these remains, identified as L.300, were exposed at a high elevation and were directly overlaid by a Persian-period wall (W.155) to the north of the gate complex, it appears that they were heavily disturbed by later occupation. As the photographs of this context reveal, the locus was sufficiently disturbed to undermine its identification as evidence of a site-wide destruction and the dating for such an event.
}

of a destruction of the LB IA Canaanite settlement to be associated with the start of Egyptian rule in Jaffa.

While Kaplan's brief report on his 1958 excavations mentioned the Egyptian assemblage, it did not make clear from which Late Bronze Age phase these ceramics originated. ${ }^{50}$ Our work has resulted in the identification of this corpus as the earliest Egyptian assemblage from Jaffa, which dates to LB IB (ca. 1460 to 1400 B.C.E.). ${ }^{51}$ The date of the assemblage therefore confirms Kaplan's date for the initial phase of Egyptian rule during the second half of the 15 th century B.C.E., 52 and it suggests that Jaffa's LB IA Canaanite settlement was replaced during LB IB by an Egyptian settlement. By examining the elevations (fig. 5) associated with the loci from which this assemblage originated, we were able to reconstruct the buildings of this phase, which we identify as level VI late (fig. 6). While the walls of these buildings align with the later gateway, they do not provide any indication of whether the Egyptian enclave was fortified at this time. Examination of this context also reveals that it was sealed by a destruction with an accumulation of more than $30 \mathrm{~cm}$ in places. The destruction debris was not confined to the roofed area of the building but identified throughout the excavation sounding, including the interior and exterior spaces of these buildings. We conclude that this context, taken together with an absence of evidence for a second phase of LB IB building, represents the destruction of the settlement of the earliest Egyptian garrison and not an accidental fire.

Within a small area delimited by W.120, 121, 131, and 133 , more than 70 vessels were recovered from the level VI late destruction debris (e.g., L.308, 309, 318) as well as an open-air pit for firing pottery (L.304) that was probably located in an exterior space connected to this building (see fig. 6). ${ }^{53}$ The level VI late ceramic assemblage consisted of a large assemblage of Egyptian

\footnotetext{
${ }^{50}$ Kaplan 1960.

${ }^{51}$ Burke and Lords 2010, 14-19.

${ }^{52}$ Kaplan 1972, 78.

${ }^{53}$ Many loci, particularly those not identified with a destruction horizon, cannot be properly assigned because they are not clearly associated with other well-dated features. Thus far, the following level VI late loci have been identified with the destruction debris: L.304, 305, 308, 309, 310, 311, 316, 318, 319, 320, and other unnumbered loci. Many additional fragmentary and restorable vessels likely belong to this destruction horizon, but owing to the limited data available to permit their restoration to this context, their association with this destruction remains uncertain, if highly probable (e.g., MHA 5327).
} 


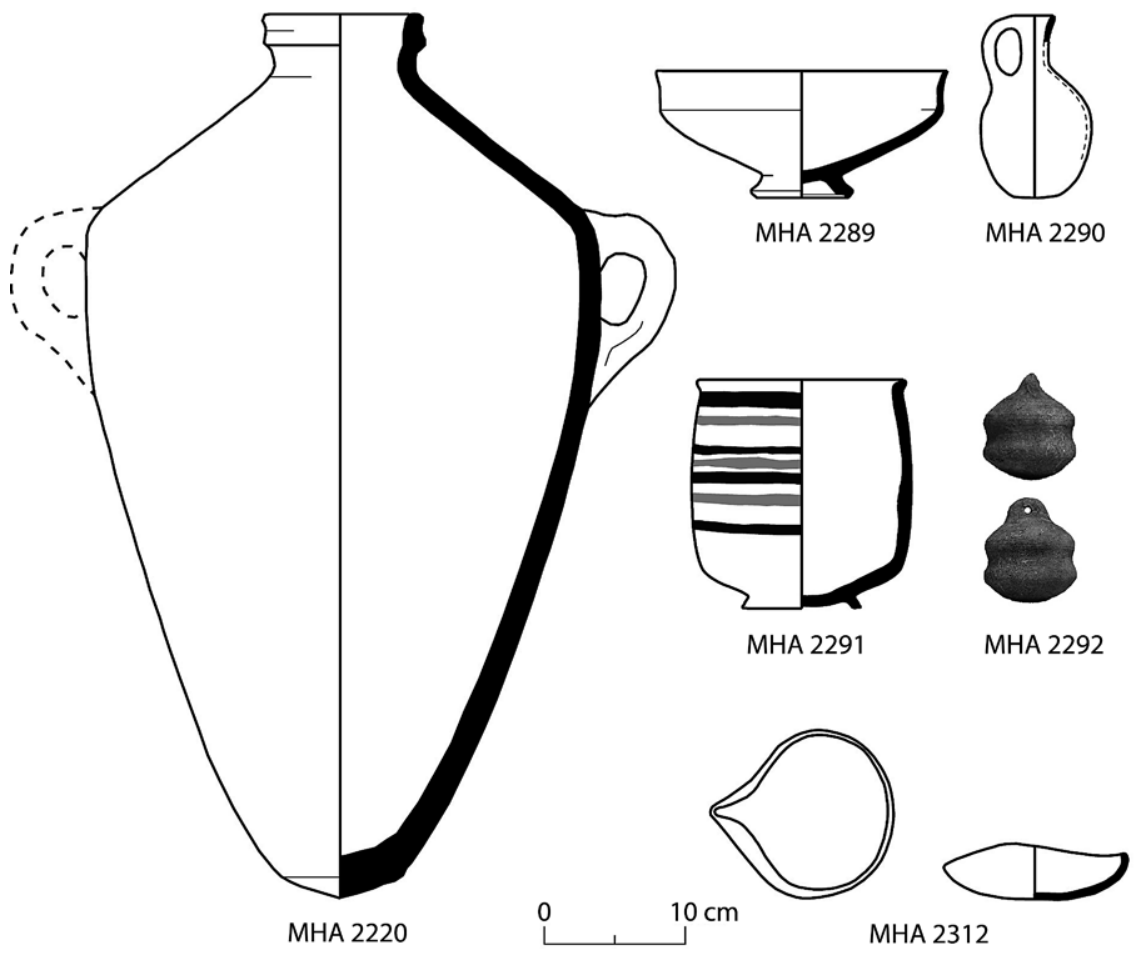

FIG. 4. Vessels belonging to infant burial (L.300) from level VI early: Canaanite jar (MHA 2220), carinated bowl with trumpet base (MHA 2289), Gray Lustrous juglet (MH 2290), bichrome "goblet" (MHA 2291), rattle (MHA 2292), and lamp (MHA 2312 ).

vessels and a few Canaanite vessels (fig. 7; table 3), which we suggest originated from a kitchen that served the first Egyptian garrison..$^{54}$ The vessels belong to a wide range of locally produced and imported Egyptian forms, all of which are associated with food storage, preparation, and consumption. Egyptian storage jars of various sizes, ring stands and pedestal pot stands, bowls, sieving bowls, imported carinated jars, and flowerpots all attest that the production of beer and bread (both of which were staples of the Egyptian diet) was of central importance in this area. ${ }^{55}$ Indeed, contemporaneous Egyptian tomb scenes show many of these vessel types being employed for such purposes. ${ }^{56}$ The

\footnotetext{
${ }^{54}$ Final publication of this assemblage is being prepared by K.V.L. Pierce and Jacob Damm for the forthcoming report on the excavations in Area A (Ramesses Gate) from 1955 to 2014.

${ }^{55}$ See Burke and Lords (2010) for color photographs of storage jars (e.g., MHA 2298; figs. 9-11); a ring stand (fig. 22); pot stands formerly identified as "funnels" (e.g., MHA 5120; figs. 15, 16); bowls; carinated jars (e.g., MHA 2297; fig. 12); and flowerpots (e.g., MHA 2229, 2234; figs. 13, 14). For a detailed discussion, see Pierce 2013.

${ }^{56}$ See discussion in Burke and Lords 2010. For 18th-Dynasty
}

pit for firing pottery (L.304) contained more than 20 flowerpots ${ }^{57}$ in addition, recovered wasters of sieving bowls, a potter's wheel (MHA 2309), and a burnishing sherd (MHA 5152) were all found within this complex. ${ }^{58}$ These illustrate the close connection between food preparation and the production of ceramic forms that is also attested among Egyptian practices, ${ }^{59}$ in contrast to Canaanite practices, where these activities were undertaken in separate areas.

scenes of sieving activity and a pottery workshop, see Tomb of Kenamun in Thebes (Davies 1930, pls. 58, 59). For a beer-production scene, see tombs published in Säve-Söderbergh 1957, 24, pl. 22.

${ }^{57}$ For discussion of the function of flowerpots, see Burke and Mandell 2011. For original photographs of the firing pit, see Burke and Lords 2010, figs. 20, 21. No exact parallels for the firing pit are known among published New Kingdom kilns (cf. Nicholson 1993, 112-15).

${ }^{58}$ For discussion and color photographs, see Burke and Lords 2010, 18-19, 22-6 (for wasters, see figs. 17, 18; for a wheel, see fig. 19).

${ }^{59}$ Bourriau et al. 2000, 135-37. The primary New Kingdom evidence comes from the Tomb of Kenamun (TT93). 


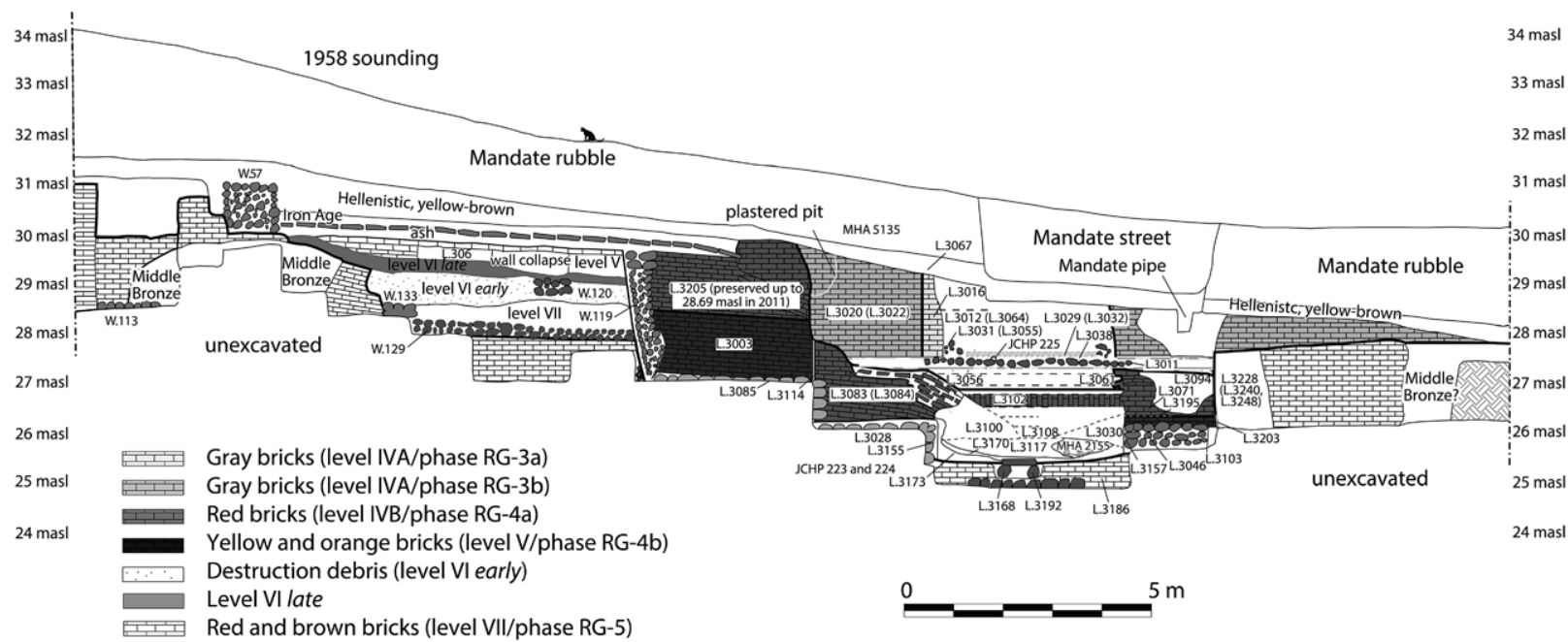

FIG. 5. Composite schematic section drawing across Ramesses Gate, as begun by Kaplan (A58-008) and continued by the JCHP (including the addition of locus numbers from renewed excavations), view to the northwest.

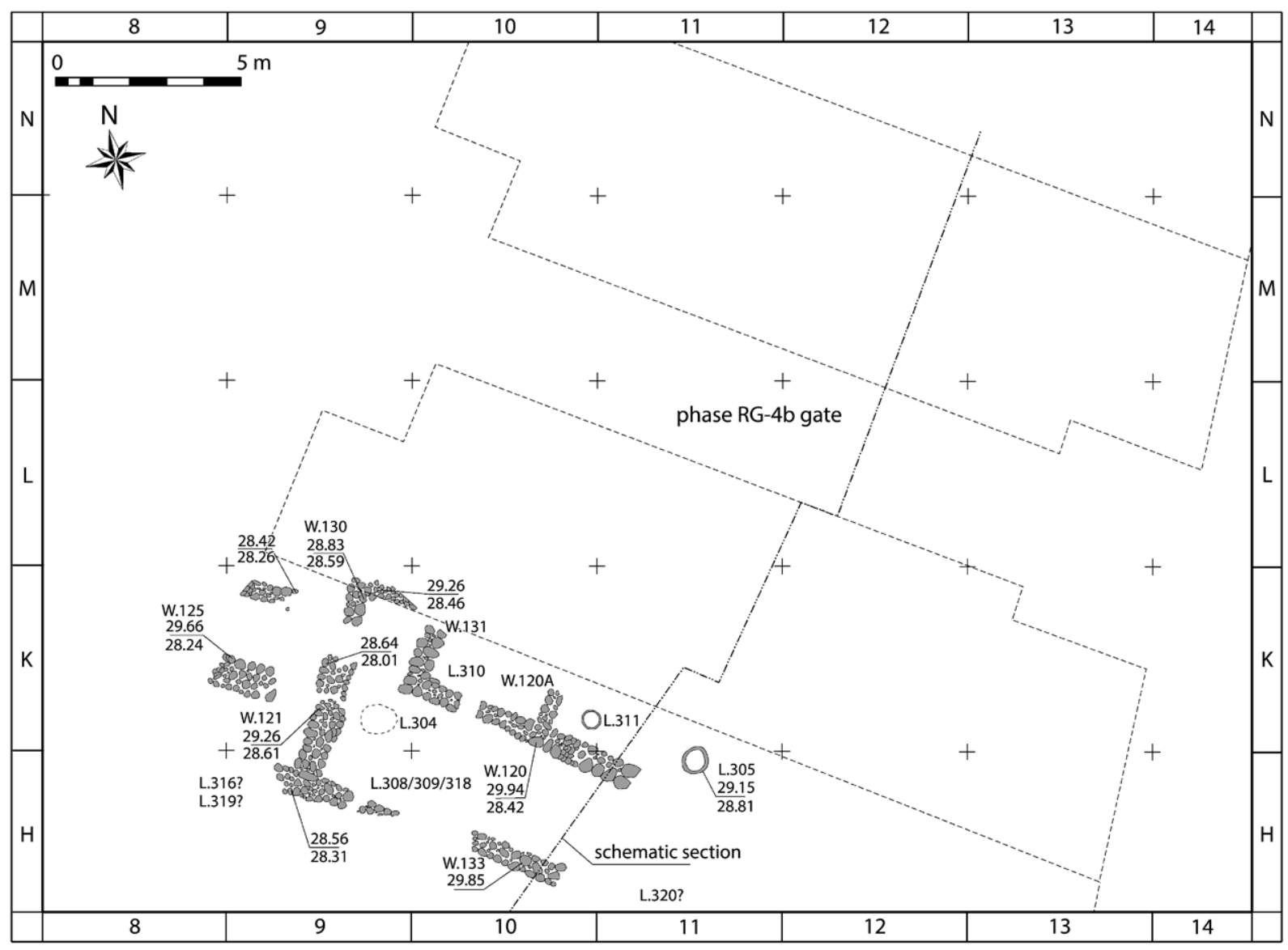

FIG. 6. Plan of Area A, level VI late garrison kitchen building and courtyard. JCHP grid system shown (drawing by K. Kowalski). All numbers with decimals indicate elevations (masl). 


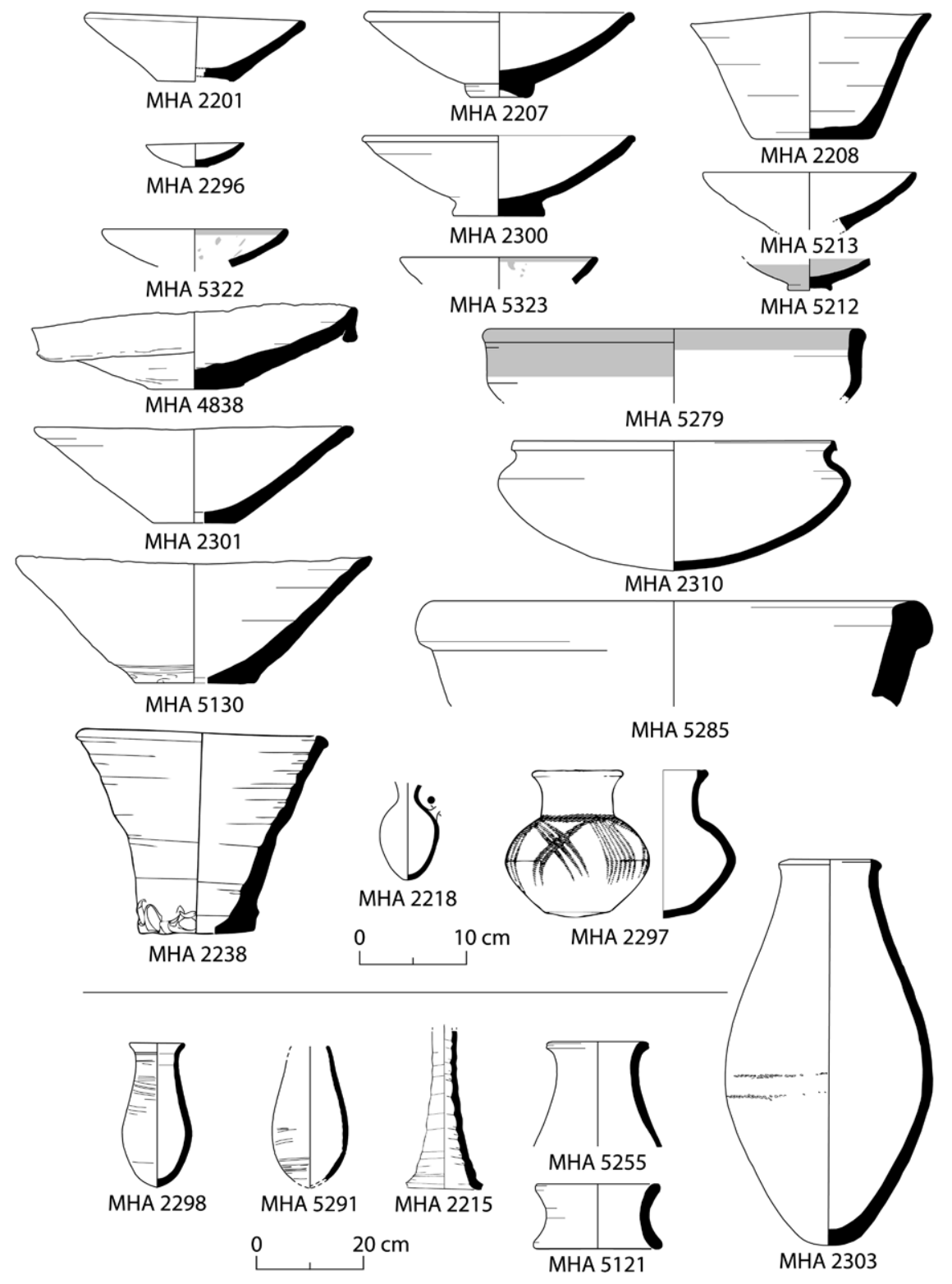

FIG. 7. Selection of ceramic forms in the level VI late destruction debris of the Egyptian garrison kitchen (see table 3).

Traditional Canaanite forms - to the extent that these were not common to the repertoire of ceramics typical of Egyptian military installations - included some bowls (e.g., MHA 2300), cooking pots (e.g., MHA 2310), a dipper juglet (e.g., MHA 2218), and pot stands (see fig. 7 ; table 3 ) ${ }^{60}$ While overwhelmingly composed of locally produced Egyptian wares that are

${ }^{60}$ These forms, which are characteristic of Late Bronze Age Canaanite assemblages where Egyptian soldiers were not resident, are also present at Egyptian garrisons in the north Sinai (cf. Oren 1987, 2006). often identified as Egyptianizing or Egyptian-style, ${ }^{61}$ the assemblage also included imported Egyptian transport containers, which suggest the maintenance of contact with Egypt during this early period of expansion.

\footnotetext{
${ }^{61}$ In arguing for the use of the descriptive qualification of many Egyptian ceramics as "Egyptian-style," Martin $(2011,23)$ notes that "the link between locally-made Egyptian types and the Egyptian pottery tradition is more complex and may occur at different levels" and that association of wares as Egyptianstyle is made on the basis of morphological, technological, or contextual considerations.
} 
TABLE 3. Summary of level VI late ceramic assemblage from kitchen area south of gate excavated by Kaplan. Types follow Martin 2011.

\begin{tabular}{|c|c|c|c|c|c|}
\hline Vessel Type & Types & $\begin{array}{l}\text { Min. No. } \\
\text { Vessels }\end{array}$ & Period, Egypt & MHA Nos. & Context(s) \\
\hline \multicolumn{6}{|l|}{ Egyptian Types } \\
\hline Bowl, simple or plain rim & $\begin{array}{l}\text { BL1, } \\
\text { BL2, } \\
\text { BL5 }\end{array}$ & 7 & New Kingdom & $\begin{array}{l}2194,2196,2201^{a}, \\
2208^{a}, 2210,5143, \\
5213^{a}\end{array}$ & $\begin{array}{l}\text { L.304, } \\
\text { L.305, } \\
\text { L.308 }\end{array}$ \\
\hline Bowl (splash decoration) & BLla & 3 & mid 18th Dynasty & $\begin{array}{l}5322^{\mathrm{a}}, 5323^{\mathrm{a}}, \\
5327(?)\end{array}$ & L.304 \\
\hline Sieving bowl (and wasters) & cp. BL5 & 10 & & $\begin{array}{l}2301^{\mathrm{a}}, 5130^{\mathrm{a}} \\
5144-5151\end{array}$ & $\begin{array}{l}\text { L.304, } \\
\text { L.309 }\end{array}$ \\
\hline Bowl, large (ledge-rimmed) & BL5c & 1 & New Kingdom & $4838^{\mathrm{a}}$ & L.318 \\
\hline Red-slip carinated bowl & BL6 & 1 & $\begin{array}{l}\text { late } 18 \text { th Dynasty } \\
\text { to 20th Dynasty }\end{array}$ & $5279^{a}$ & L.309 \\
\hline Flowerpot & FP & 20 & 18th Dynasty & $\begin{array}{l}2221-2238^{\mathrm{a}}, 2239 \\
2302\end{array}$ & L.304 \\
\hline Ovoid jar, small & JR1 & 2 & $\begin{array}{l}\text { mid 18th Dynasty } \\
\text { to } 21 \text { st Dynasty }\end{array}$ & 5269,5286 & L.318 \\
\hline Ovoid jar, medium & JR2 & 4 & $\begin{array}{l}\text { SIP to } 18 \text { th } \\
\text { Dynasty }\end{array}$ & $\begin{array}{l}2298^{\mathrm{a}}, 5274,5290, \\
5291^{\mathrm{a}}\end{array}$ & $\begin{array}{l}\text { L.308, } \\
\text { L.318 }\end{array}$ \\
\hline Ovoid jar, tall (zir) & & 1 & early 18 th Dynasty & $2303^{a}$ & L.308 \\
\hline Carinated jar, small & JR7 & 3 & 18th Dynasty & $2216,2297^{\mathrm{a}}, 5211$ & L.308 \\
\hline Storage jar (zir) & JR10 & 2 & $\begin{array}{l}\text { late SIP to late } \\
\text { 18th Dynasty }\end{array}$ & $5255^{\mathrm{a}, \mathrm{b}}, 5268^{\mathrm{b}}$ & L.318 \\
\hline Stand, ring & - & 2 & - & $5121^{\mathrm{a}}, 5141$ & $\begin{array}{l}\text { L.308, } \\
\text { L.309 }\end{array}$ \\
\hline Stand, tubular & - & 6 & - & $\begin{array}{l}2215^{a}, 5120,5136, \\
5137,5138(5139), \\
5262\end{array}$ & $\begin{array}{l}\text { L.308, } \\
\text { L.309, } \\
\text { L.318 }\end{array}$ \\
\hline \multicolumn{6}{|c|}{ Types Traditionally Identified As Canaanite } \\
\hline Bowl & - & 5 & - & $\begin{array}{l}2193,2207^{\mathrm{a}}, 2296^{\mathrm{a}}, \\
2300^{\mathrm{a}}, 5212^{\mathrm{a}}\end{array}$ & $\begin{array}{l}\text { L.304, } \\
\text { L.308, } \\
\text { L.310 }\end{array}$ \\
\hline Bowl or vat, large (everted rim) & - & 1 & - & $5285^{\mathrm{a}}$ & L.308 \\
\hline Cooking pot & - & 2 & - & $2214,2310^{a}$ & L.316 \\
\hline Dipper juglet & - & 1 & - & $2218^{a}$ & L.309 \\
\hline Stand, ring & - & 1 & - & 5294 & L.304 \\
\hline Stand, tubular & - & 1 & - & 5263 & L.318 \\
\hline
\end{tabular}

Total $\quad-\quad 73$

SIP $=$ Second Intermediate Period

${ }^{\text {a }}$ MHA items illustrated in fig. 7.

${ }^{\mathrm{b}}$ Limited percentage of overall vessel preserved. 
The vessels seen in figure 7 include both storage jars (e.g., MHA 2303) and small, decorated carinated jars (e.g., MHA 2297) ${ }^{62}$ that may have contained ingredients such as dates or honey to be specifically included in beer for Egyptian consumption. ${ }^{63}$

The assemblage described is typically associated with LB IB, and its preliminary identification has been confirmed in a recent assessment of Egyptian ceramics in Canaan during the Late Bronze Age. ${ }^{64}$ As in figure 7, the strongest markers for a LB IB date are the red-splash decorated bowls attested only as late as Amenhotep II's reign (MHA 5322 and 5323); ${ }^{65}$ carinated jars that are traditionally dated to the reign of Thutmose III (MHA 2297); ${ }^{66}$ the medium-broad ovoid jar (MHA 2303);67 and the large assemblage of 20 flowerpots (e.g., MHA 2238) that are not attested at Amarna, the ceramics of which serve as the traditional basis for identifying late 18th-Dynasty assemblages. ${ }^{68}$ A partially red-slipped carinated bowl (MHA 5279) is also in keeping with red-slip decoration on the upper parts of open forms that was common on early 18 th-Dynasty bowls. ${ }^{69} \mathrm{~A}$ large number of the most frequently attested types within this assemblage originate from but a handful of loci (e.g., L.304 and L.308 [L.309, 318]), including the flowerpots and the imported, painted carinated jars.

The chronological span for the assemblage and consequently its deposition may, however, extend slightly later than the beginning of the 14th century B.C.E. This observation results from painstaking efforts to reconstruct the full list of loci that were associated with this context within the sounding to the south of the gate. For example, Canaanite cooking pots within this assemblage that first appear in LB IIA suggest an early LB IIA terminus post quem for the assemblage (i.e., ca. 1400 B.C.E.; see MHA 2310 in fig. 7). ${ }^{70}$ Thus,

\footnotetext{
${ }^{62}$ For color photographs, see Burke and Lords 2010, figs. 10 (broad ovoid jar formerly identified as a "neckless storage jar"), 12 (carinated jar).

${ }^{63}$ For discussion, see Pierce 2013. For comestibles included in beer production, see also Samuel 2000, 548-49.

${ }^{64}$ Burke and Lords 2010; Martin 2011, 238-40.

${ }^{65}$ Martin 2011, 32.

${ }^{66}$ Martin 2011, 240.

${ }^{67}$ Wodzińska 2010, 89. While our example has a higher waist and lacks incision around the neck, the form, including the rim, is the same.

${ }^{68}$ Wodzińska 2010, 55-155; Martin 2011, 48.

${ }^{69}$ Martin 2011, 44. These continue to be found in LB IIB contexts.

${ }^{70}$ Amiran 1970, pl. 42.
}

although the assemblage consists predominantly of mid 18th-Dynasty forms from the late 15th century B.C.E., ceramic types typical of the 14th century B.C.E. also appear, underscoring the challenges of dating an assemblage encountered in a small sounding on the basis of a few well-stratified assemblages in Egypt. ${ }^{71}$

\section{Level V: LB IIA}

The primary feature from the 1958 sounding assigned to level V was a small installation (L.306), which Kaplan identified as a silo and dated to the 14th century B.C.E. on the basis of ceramics. ${ }^{72}$ This structure was, however, likely a small firing installation that replaced the open kiln (L.304) of level VI late. ${ }^{73}$ Although this feature was enclosed by a series of rectilinear walls (W.115, 116, 118, 119) suggestive of its inclusion in a larger complex of the early fortress, our understanding of this phase is severely limited when compared with that of both the preceding and succeeding phases. This is mostly owing to the scant cultural remains excavated by Kaplan that were assigned to LB IIA (i.e., level V). Kaplan therefore apparently identified the level V silo with the Amarna-period occupation of Jaffa during the 14th century B.C.E. on the basis of ceramic finds. ${ }^{74}$

\section{Level IVB: LB IIB}

Following level V, a massive Egyptian gate complex was erected in this location. ${ }^{75}$ According to Kaplan, the Egyptian fortification wall connected to the level IVB gate was constructed atop the Middle Bronze Age wall remains, ${ }^{76}$ having been cut "deep into" earlier layers

\footnotetext{
${ }^{71}$ A major problem with Egyptian archaeological dating of ceramic forms to particular reigns is a dependence on a limited set of Egyptian settlement contexts (e.g., Amarna, Tell ed-Dab a), upon which such determinations rely. With this in mind, we recognize that such dates are subject to modification in the future.

${ }^{72}$ Kaplan and Ritter-Kaplan 1993, 656-57.

${ }^{73}$ This identification is suggested from the Hebrew description of the material from this installation on an unpublished section drawing. The description translates to "ash from tannur" (1958, section no. A58-008, Kaplan Archive). All items in the Kaplan Archive are in the collections of the IAA in Jerusalem.

${ }^{74}$ Kaplan 1972, 79.

${ }^{75}$ Kaplan and Ritter-Kaplan 1993, 656.

${ }^{76}$ Kaplan 1960, 121. Although Middle Bronze Age remains were not identified during renewed fieldwork, there is little reason to doubt Kaplan's assertion concerning their presence based on the discrepancy in elevation between the level of the LB IIB gate passage and the contemporaneous occupationallevels within the fortress. These illustrate, as suggested by Kaplan,
} 
(see fig. 5). ${ }^{77}$ No plans of the gateway were ever published, however, and Kaplan noted only that the gate's passage was approximately $18 \mathrm{~m}$ long $\mathrm{x} 4 \mathrm{~m}$ wide. A schematic, preliminary plan was eventually published by Tel Aviv University based on limited soundings in the late 1990s and a heavy reliance on Kaplan's stratigraphic sequence. $^{78}$

Kaplan attributed the construction of the level IVB gate to Ramesses II on the basis of fragments of the monumental, sandstone facade that were inscribed with his name but found reused in the construction of the following phase (i.e., level IVA). The fragments preserve the names of Ramesses II. ${ }^{79}$ As indicated by the reconstruction of the original facade, slightly less than half of the facade was recovered during Kaplan's excavations (fig. 8). Carved from local kurkar sandstone, inscribed with hieroglyphs, plastered with lime, and painted in yellow and red, these blocks are the most conspicuous artifacts from New Kingdom Jaffa recovered to date. Having found them in reuse as architectural elements in the later level IVA gate, Kaplan concluded that the fragments had actually been removed from the debris of the level IVB destruction. ${ }^{80}$ If he was correct, then the facade fragments were not buried in the collapsed debris within the passageway, because they were arranged at the entrance on the gate's eastern, exterior elevation, from which they likely tumbled down the slope of the mound. The plinths for the facade were also identified on both sides of the entryway, as well as the roadway leading from the threshold to the southeast (fig. 9).

Kaplan never provided a full account of what he recovered from the destruction debris at the eastern end of the gate, noting simply that the remains of the level IVB and IVA gates "were only partially cleared." ${ }^{11}$ However, in his earlier synthesis he mentions "the upper portion of a stone altar $1.0 \times 1.2 \times 0.22 \mathrm{~m}$ and two fragments of a large pithos" $1.2 \mathrm{~m}$ tall with a $0.82 \mathrm{~m}$ diameter. ${ }^{82}$ While the JCHP has not been able to identify any item fitting the description of an altar, the

that the Egyptian gate's foundation was dug down into earlier occupational remains.

${ }^{77}$ Kaplan $(1972,81)$ originally designated this context level V, only later calling it level IVB (Kaplan and Ritter-Kaplan 1993, 656).

${ }^{78}$ Herzog 2008, 1791.

${ }^{79}$ Kitchen 1994, no. 401, line 5.

${ }^{80}$ Kaplan 1972, 81-2.

${ }^{81}$ Kaplan and Ritter-Kaplan 1993, 656.

${ }^{82}$ Kaplan 1972, 79. pithos appears to be the restored Cypriot pithos on display at the Jaffa Museum (MHA 2155; fig. 10). Although Kaplan maintained that the destruction of this gate dated to the "third quarter of the 13th century," in earlier discussions he attributed the level IVB destruction to Sea Peoples who "occupied the Jaffa area" (i.e., in the early 12 th century). ${ }^{83}$

\section{Level IVA: LB III}

The next phase of the gate, level IVA, was rebuilt to identical dimensions, with gray mudbricks, atop the destroyed remains of the level IVB gate. ${ }^{84}$ Fragments of the aforementioned gate facade of Ramesses II were found in reuse along the gate's passageway (fig. 11). The use of gray bricks in the towers of this gate (see fig. 5 , L.3020 [L.3022]) reveal the use of occupational debris with high ash content for the production of bricks. Two important artifacts were also recovered from this gate's bricks. One is the upper part of a ceramic "Qudshu" goddess plaque recovered by Kaplan (fig. 12; MHA 5135), which bears influences of both Canaanite and Egyptian religious iconography. ${ }^{85}$ The other important artifact, the Lion Hunt scarab of Amenhotep III, was found by the Tel Aviv University expedition in 1999. ${ }^{86}$

The conflagration associated with the level IVA gate put an end to Egyptian habitation in Jaffa. In 1956, Kaplan identified stunning evidence of the burning of the fortress when he exposed the gate's eastern threshold. There, within the ash on the southern side of the threshold, lay one of the two $30 \mathrm{~kg}$ bronze gate hinges (MHA 5128) that belonged to the final gate. It was oriented as it had been when the doors of the gate were burned during the final assault (fig. 13). ${ }^{87}$ The hinge was filled with the charred remains of wood from one of the doors, which was no less than $20 \mathrm{~cm}$ thick, with the nails still protruding from its bronze casing. ${ }^{88}$ In an effort to identify the historical context of this destruction, at different stages during his research Kaplan

\footnotetext{
${ }^{83}$ Kaplan 1972, 81; Kaplan and Ritter-Kaplan 1993, 656.

${ }^{84}$ Kaplan and Ritter-Kaplan 1993, 656.

${ }^{85}$ Kaplan 1972, 81. Identified by Michael Press.

${ }^{86}$ TAU 517/80 (Sweeney 2003; see also Herzog 2008).

${ }^{87}$ This artifact was stolen, seemingly for its weight as scrap metal, within days of its excavation. We would like to thank Omri Lernau for assisting us in reconstructing and documenting this forgotten and unfortunate episode in Jaffa's archaeological history. The artifact on display in the Jaffa Museum is therefore a facsimile created from preliminary drawings and photographs of the object.

${ }^{88}$ Kaplan 1956, 260.
} 


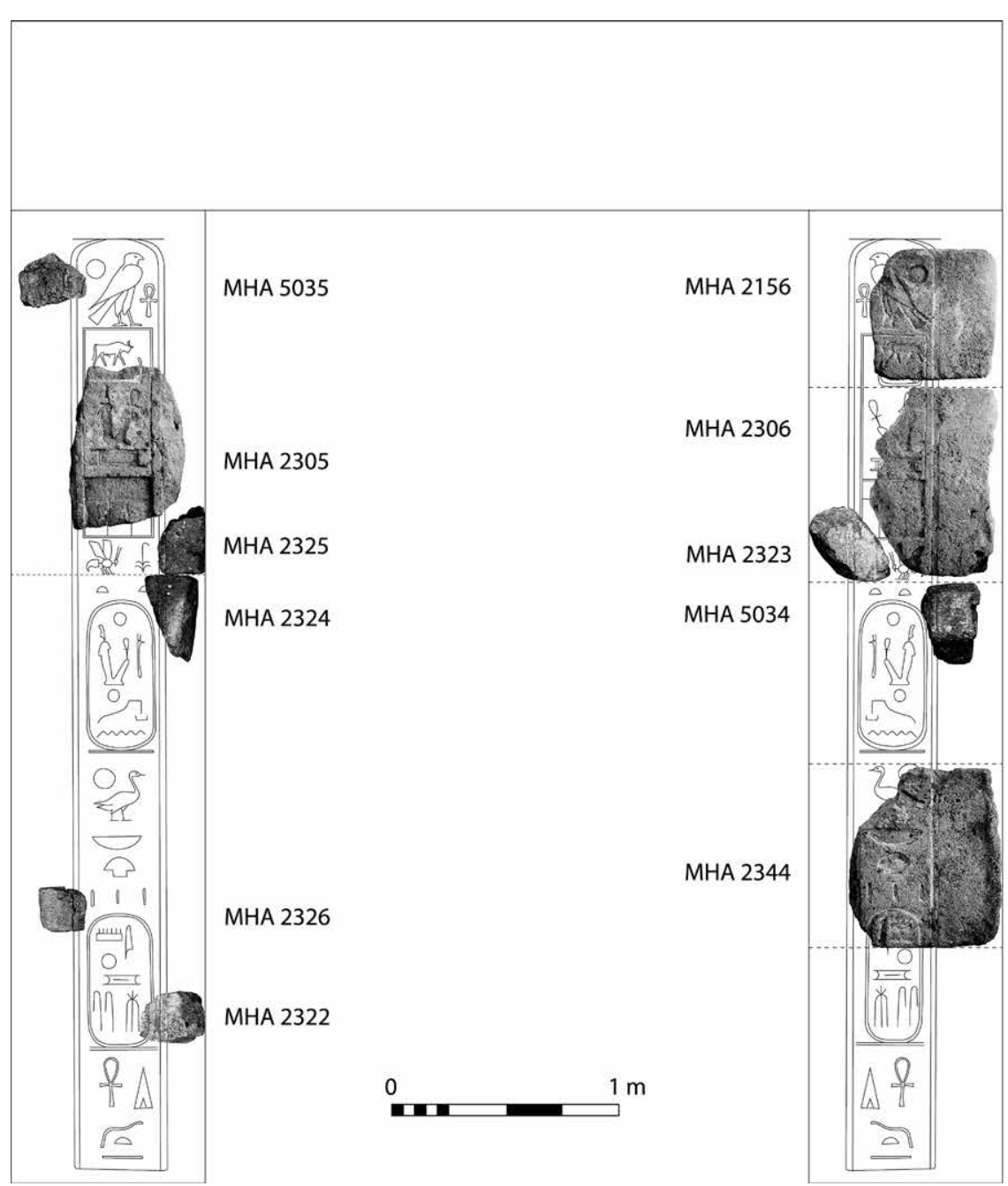

FIG. 8. Level IVB (phase RG-4a) portal facade of Ramesses II, reconstructed from fragments excavated by Kaplan from level IVA (phase RG-3a) (drawing by A. Karoll).

had assigned the level IVA destruction either to the rebellion during the reign of Merneptah or to the Sea Peoples. ${ }^{89}$ Perhaps because the Tel Aviv University expedition claimed not to have encountered evidence for this destruction in their limited soundings of the level IVA gate, Herzog did not suggest a precise date for this level's end. ${ }^{90}$

${ }^{89}$ Kaplan 1960, 121; 1972, 82; Kaplan and Ritter-Kaplan 1993, 656.

${ }^{90}$ Herzog 2008, 1792. There is no reason to believe based on the 2011 excavations that Herzog excavated any substantial portion of the phase RG-3a gate during the 1990s, having encountered instead only the road foundation left by Kaplan to the east of the remains of the so-called Sidonian Wall (W.3) dated to the Persian period. The only part of this that remained to be excavated lay directly below the Persian-period wall, whence originated

\section{Level IIIB: Late Iron I to Early Iron IIA}

Above the final phase of the Egyptian gate, Kaplan encountered pits in a beaten-earth floor of level IIIB. It contained late Philistine ceramics of the type now identified as Philistine 3 and dated to the late Iron I to early Iron IIA (ca. 1100-900 B.C.E.). ${ }^{91} \mathrm{He}$ dated this context to the 11 th century B.C.E., comparing the assemblage

the stratigraphic sequence described below in the section "Preliminary Report on the Renewed Excavations, 2011-2014."

${ }^{91}$ For published photographs, see Burke 2011a, 70-1, fig. 6.5. Philistine 3 is the latest phase in the development of Philistine ceramics (Ben-Shlomo 2006), following Philistine 1 and Philistine 2, terms that were introduced by the Tel Miqne-Ekron Excavations for Philistine Monochrome and Philistine Bichrome (Dothan et al. 2006, 80-91). 


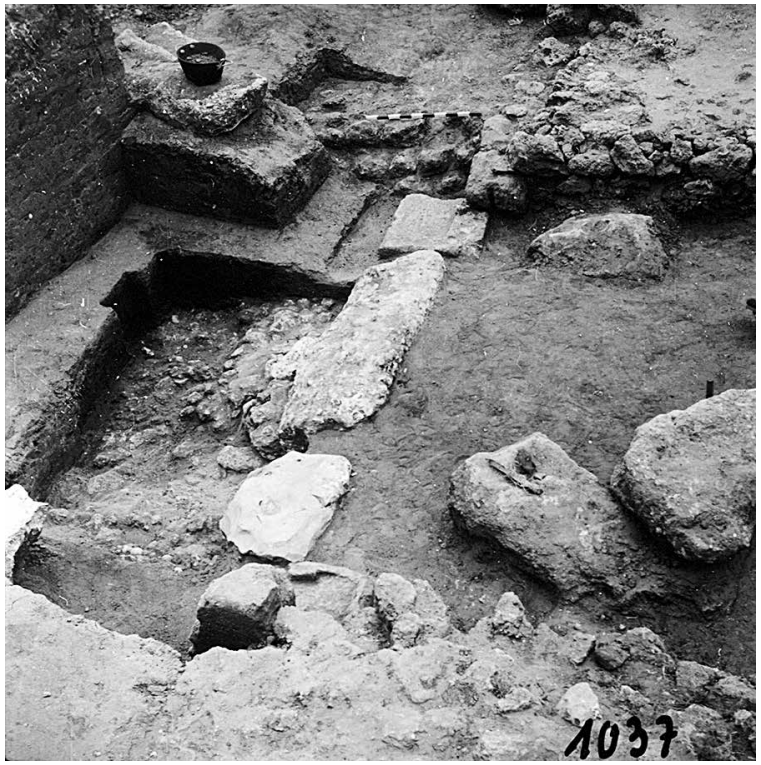

FIG. 9. Eastern threshold of level IVB (phase RG-4a) gate and sloped roadway (at left), as exposed during 1962 excavations by Kaplan, view to the south. Note that the large stones seen to the right within the passageway belong to the level IVA threshold, which fell into the excavation area following its exposure in 1956 (field photograph 1037, Kaplan Archive; courtesy Israel Antiquities Authority).

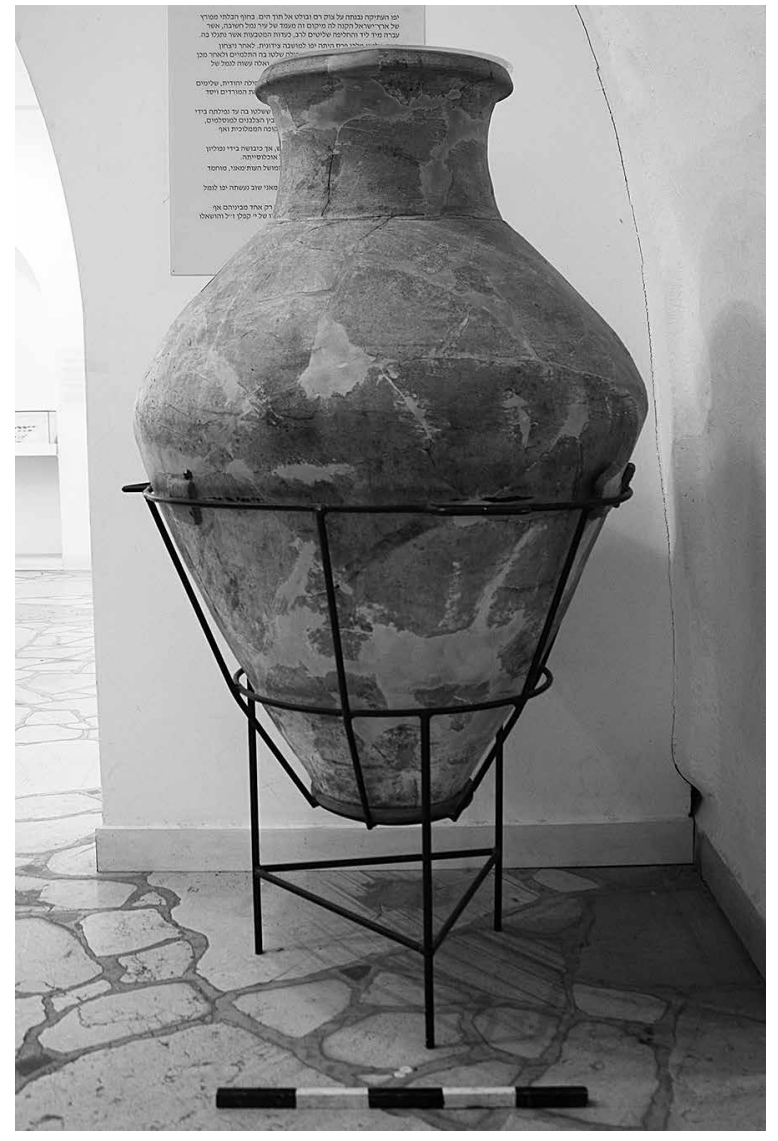

FIG. 10. Late Cypriot pithos (MHA 2155) recovered from level IVB (phase RG-4a) destruction.
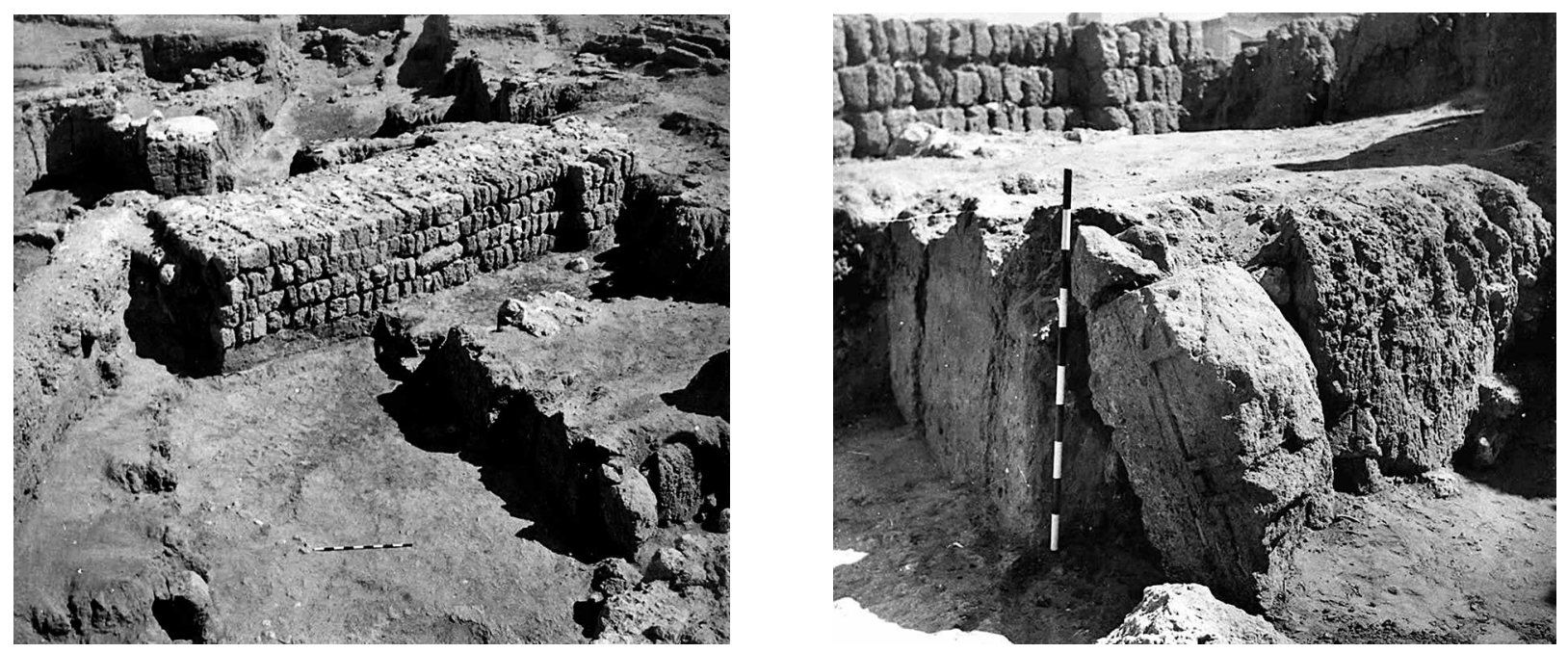

FIG. 11. Phase RG-3a gate complex passageway following excavations in 1956, views to east in both photographs. A fragment of the Ramesses II portal facade (MHA 2306) originally from level IVB (phase RG-4a) was reused as an orthostat within the level IVA (phase RG-3a) gate complex, as seen in lower right (left) and close-up (right) (field photographs 701 and 866, Kaplan Archive; courtesy Israel Antiquities Authority). 


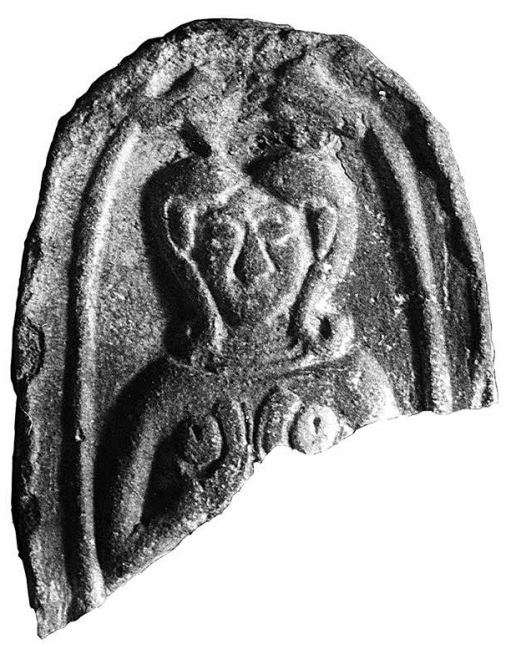

FIG. 12. "Qudshu” terracotta plaque figurine fragment from level IVA (phase RG 3b) brickwork (field photograph 6208, Kaplan Archive; courtesy Israel Antiquities Authority).

to that of Tel Qasile XI. ${ }^{92}$ Although he published no photographs or drawings of these ceramics, his dating of the context is reasonable. The largest of these deposits (L.9 [L.307]) has been analyzed by the JCHP, revealing a collection of debased Philistine bell-shaped bowls and kraters of the type identified as a degenerate Philistine ware (fig. 14). As reckoned by Kaplan, a gap of possibly 50-100 years therefore existed between the destruction of the final Egyptian gate of level IVA and the short-lived Philistine settlement of the 11th century B.C.E. ${ }^{33}$ These remains were buried below various elements from the Iron II (level IIIA), Persian (level II), and Hellenistic (level I) periods, though no coherent settlement plans could be reconstructed for these levels.

The preceding review of Jaffa's history and archaeology until just after the end of Egyptian rule reveals the limitations of these data, particularly since approximately $10 \mathrm{~m}$ of the passageway remained unexcavated following both Kaplan's and Herzog's excavations. After these excavations the plans of each phase of the gate still remained unclear. Additionally, none of the contexts reviewed was subjected to intensive sift ratios or flotation, which could provide the opportunity for

\footnotetext{
${ }^{92}$ Kaplan 1972, 83. For Tel Qasile Philistine ceramics, see Mazar 1985, 87-108.

${ }^{93}$ This "gap in the occupation" is mentioned in an early synthesis (Kaplan 1972, 83) but not in the last overview of the stratigraphic sequence exposed in Kaplan and Ritter-Kaplan 1993, 656 .
}
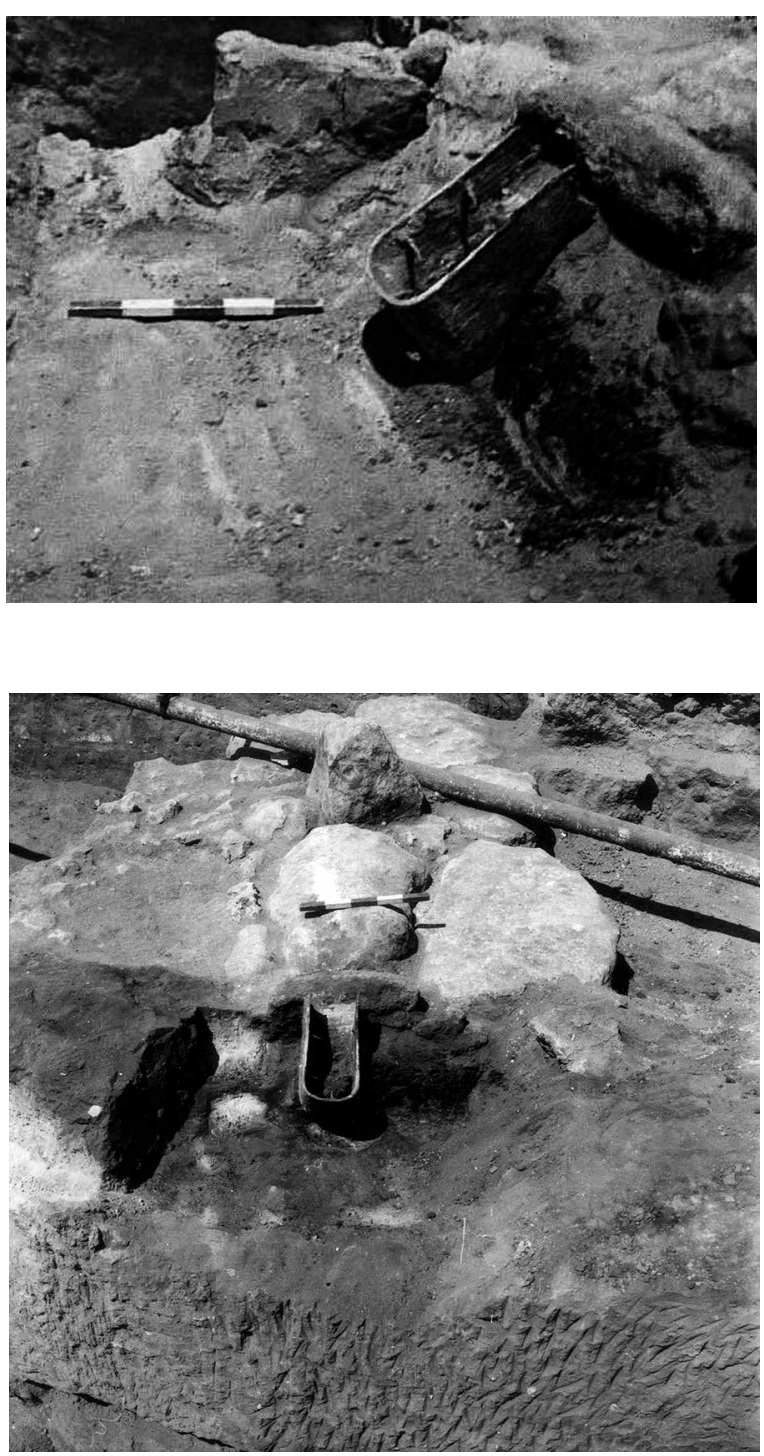

FIG. 13. Bronze gate hinge (MHA 5128) in situ within the level IVA (phase RG-3a) destruction debris in 1956, view to northwest (top) and north (bottom). In the bottom photograph, a British Mandate pipe appears in background, lying across threshold (field photographs unnumbered and 805, Kaplan Archive; courtesy Israel Antiquities Authority).

scientific analyses, such as faunal, botanical, residue, and radiocarbon sampling. Thus, ample room remains for further filling these lacunae through renewed excavations.

\section{PRELIMINARY REPORT ON THE RENEWED \\ EXCAVATIONS, 2011-2014}

From 2011 to 2014, the JCHP renewed excavation of the New Kingdom Egyptian gate complex focused 


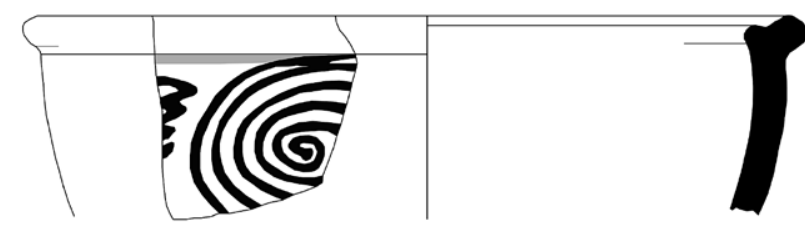

MHA 2138

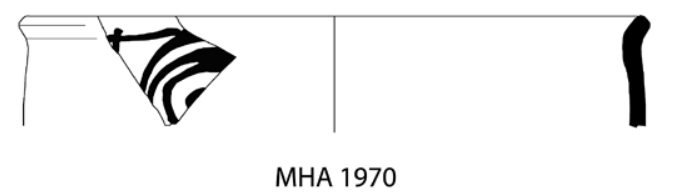

MHA 1970

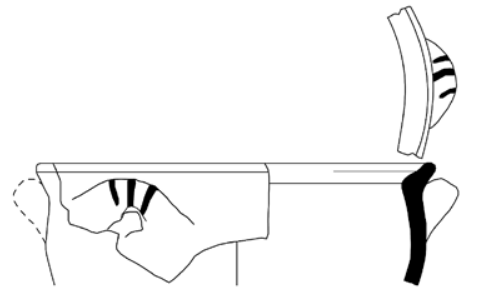

MHA 1992

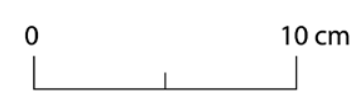

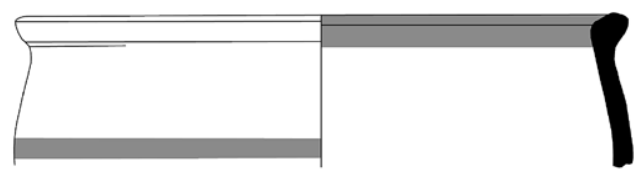

MHA 1981

FIG. 14. Philistine ceramics from Kaplan's excavation of refuse pit L.9 (L.307) in level IIIB: bell-shaped bowls (MHA 1992, 1970) and bell-shaped kraters (MHA 2138, 1981) of the Philistine 3 (debased) type.

on the Ramesses Gate portion of Area A (see fig. 3). ${ }^{94}$ Owing to constraints associated with simply adopting the existing designations of "levels" identified by Kaplan, as discussed above, the renewed excavations introduced "phases" for elements of the archaeological

\footnotetext{
${ }^{94} \mathrm{JCHP}$ excavations were conducted from 10 July to $4 \mathrm{Au}-$ gust 2011 (license no. G-35/2011), 1 July to 2 August 2012 (license no. G-44/2012), 17 June to 2 August 2013 (license no. G-60/2013), and 27 June to 1 August 2014 (license no. G-33/2014). Staff included G.A. Pierce (2011-2012), B. Kaufman (2011), H. Dodgen (2011-2013), A. Karoll (2011-2014), N. Ben-Marzouk (2012-2013), A. Danielson (2013-2014), J. Damm (2013-2014), and Z. Margulies (2012); K. Kowalski, GIS (2011-2014); K.V.L. Pierce (2012) and E. Waraksa (2013), Egyptian specialists. Support in 2011 included UCLA Senate Faculty Research, Field Research (Cotsen Institute, UCLA), and Ross Travel (Center for Jewish Studies) grants and the Seminar für Altes Testament und Biblische Archäologie (Johannes Gutenberg University, Mainz). The IAA provided logistical support from 2011 to 2013. Support in 2012 featured the UCLA Transdisciplinary Seed Grant (Office of the Vice Chancellor for Research) and a grant from the Near Eastern Languages and Cultures Department. Additional support included UCLA Graduate Summer Research Mentorships and fellowships from the American Schools of Oriental Research. Since 2013, the archaeological excavations have been supported by a National Endowment for the Humanities collaborative grant under the title "Insurgency, Resistance, and Interaction: Archaeological Inquiry into New Kingdom Egyptian Rule in Jaffa" (RZ-51445-12).
}

sequence encountered in the Ramesses Gate, which are prefixed with "RG-."95 Correlations are suggested between each RG "phase" and Kaplan's respective "level" with the added caveat that new architectural phases were identified during renewed excavations (table 4). Attention to the sequence of architectural modifications, along with the dates provided by ceramic assemblages and radiocarbon samples, permits a refinement of the dates assigned for the destruction of each of the gate's major phases.

Phase RG-5: Middle Bronze Age Gate Architecture?

The earliest remains encountered during the JCHP's excavations were those of phase RG-5 (fig. 15; see table 4), which consisted of mudbrick architecture (L.3186) and rows of stones (L.3180, 3198) lying under the remains of the level IVA gateway (our phase RG-4b). These features were encountered during excavation of the floor of the RG-4a passageway in 2013. Although no definitive plan could be identified, the brickwork (L.3186) continued under the stone foundation of the northern and southern towers of the RG-4b Egyptian gate (see fig. 5). In the absence of finds associated with

\footnotetext{
${ }^{95}$ The prefix "LT-" was also introduced in 2014 for the archaeological phasing of the Lion Temple area on the west side of Area A.
} 
TABLE 4. Area A, Ramesses Gate phases excavated from 2011 to 2014.

\begin{tabular}{|c|c|c|c|c|}
\hline Phase & Architectural Feature(s) & Period & Approximate Dates & Kaplan Level \\
\hline RG-1 & Persian wall (W.3) conservation & modern & late 1950 s C.E. & - \\
\hline RG-2a & fortification wall foundation (W.3) & Persian & 500-332 B.C.E. & $\mathrm{II}(\mathrm{A})$ \\
\hline RG-2b & occupation prior to $\mathrm{W} .3$ & Persian & 550-500 B.C.E. & $\mathrm{II}(\mathrm{B})$ \\
\hline RG-3a & $\begin{array}{l}\text { gate renovations of gray bricks; } \\
\text { destruction by fire }^{\mathrm{a}}\end{array}$ & LB III (20th Dynasty) & $?-1125^{\text {a B.C.E. }}$ & IVA \\
\hline RG-3b & gate complex of gray bricks & LB III (20th Dynasty) & 1135-? B.C.E. & IVA \\
\hline RG-4a & $\begin{array}{l}\text { gate complex of red bricks and } \\
\text { black mortar; addition of facade } \\
\text { of Ramesses II; destruction by fire }\end{array}$ & $\begin{array}{l}\text { LB IIB-III (19th Dynasty } \\
\text { to early } 20 \text { th Dynasty) }\end{array}$ & $\begin{array}{l}1300-1135^{\mathrm{a}} \\
\text { B.C.E. }\end{array}$ & IVB \\
\hline RG-4b & gate complex of yellow-orange bricks & LB IIA (late 18th Dynasty) & 1400-1300 B.C.E. & $\mathrm{V} ?$ \\
\hline- & not encountered & LB IA-IB & 1550-1400 B.C.E. & VI \\
\hline RG-5 & $\begin{array}{l}\text { mudbrick remains of fortifications } \\
\text { (gate?) }\end{array}$ & MB II? & pre-1550 B.C.E. & VII? \\
\hline
\end{tabular}

${ }^{\text {a }}$ Date based on radiocarbon samples.

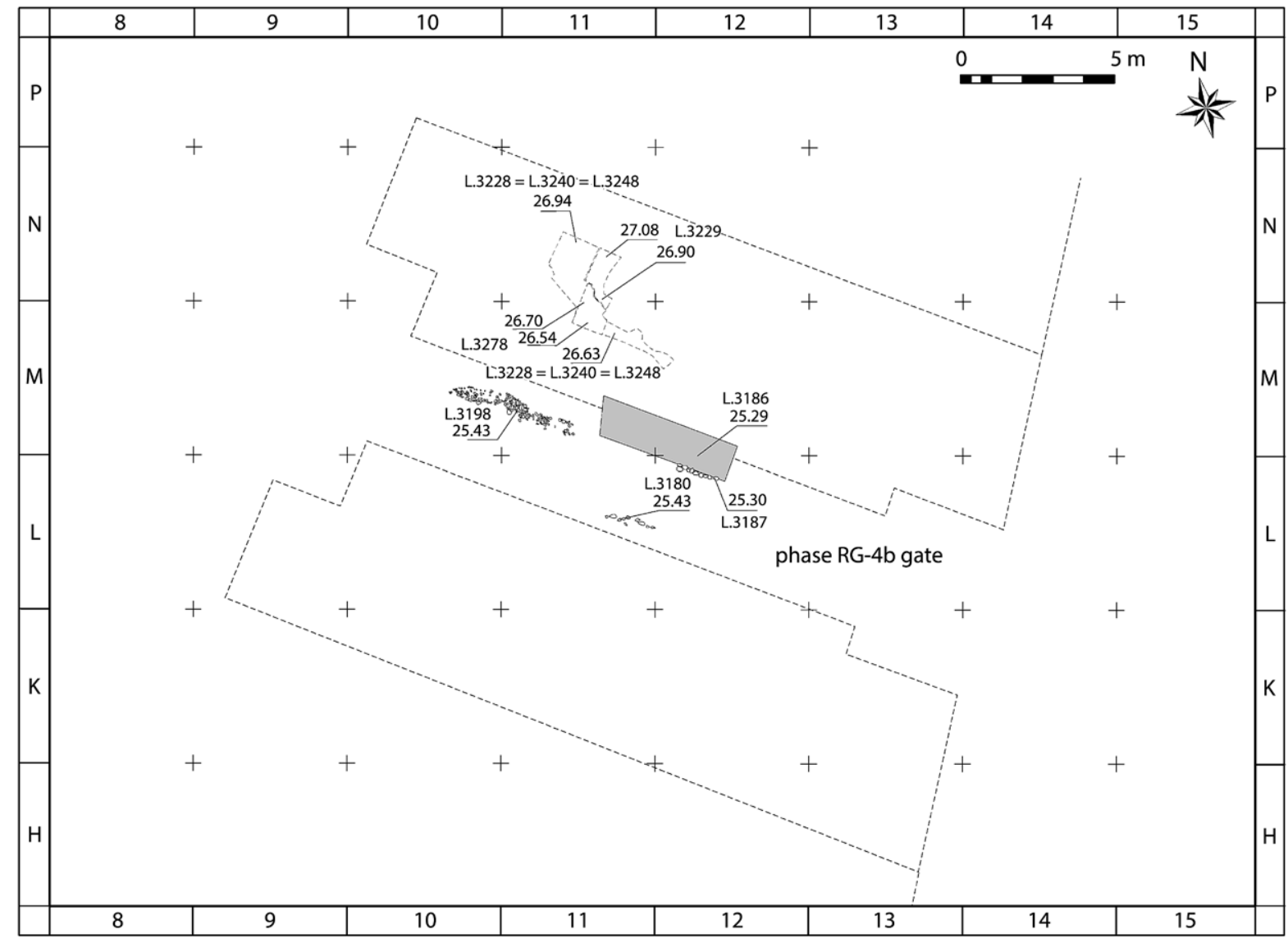

FIG. 15. Plan of the remains of phase RG-5 identified in Area A, with outlines of the later gate complex (drawing by K. Kowalski). All numbers with decimals indicate elevations (masl). 
the RG-5 features and based on the depth at which they appear, below the occupational layers of level VII south of the gate, they are tentatively identified with a phase of the Middle Bronze Age fortifications (level VII), possibly the city gate.

\section{Phase RG-4b: The Egyptian Gate's Construction}

Although Kaplan encountered substantial remains of the mudbrick superstructure of the level IVB gate, the renewed excavations revealed that Kaplan's level IVB gate actually comprised two distinct phases, designated by the JCHP as RG-4b (fig. 16) and RG-4a (see table 4). Kaplan observed that the level IVB gate was "dug deep" into the site's stratigraphy, ${ }^{96}$ an observation confirmed by the previously unpublished section drawing (see fig. 5). Evidently, although he identified two different brickwork elements belonging to the level IVB gate, L.3003 and L.3083 (L.3084) as numbered by the JCHP, he did not qualify these as two separate phases of the gate. A review of the gate's stratigraphy based on the renewed excavations establishes, however, that level IVB indeed consists of two phases that were distinguished not only by their entirely different brickwork but also by evidence for the erosion of the RG- $4 \mathrm{~b}$ brickwork, which is evidence for a gap in time between the constructions of RG-4b and RG-4a and the deliberate separation of these phases by means of a plaster layer.

The smaller stones at the top of the retaining wall (W.119, ca. 29.5 masl; see fig. 5), which were added just after the excavation of this area, suggest that the cut made in preparation for the RG- $4 b$ gate's construction was made directly into the level VI late destruction debris and not into level $\mathrm{V}$ as implied in Kaplan's stratigraphic sequence. While this can no longer be checked in the field, it suggests that the phase RG-4b gate may, in fact, be contemporaneous with Kaplan's level V. Elsewhere the digging for the gate's construction exposed RG-5 mudbrick architecture in the floor of the passageway, as noted above. The RG- $4 \mathrm{~b}$ gate therefore constitutes a distinct phase immediately preceding the remains Kaplan identified as the level IVB gate. After the trench for the gate was cut, boulder foundations (L.3085, 3046; fig. 17) were added. The use of stone foundations is relatively uncommon in Egyptian architecture but typical of Levantine building customs, ${ }^{97}$ where it was intended to drain moisture from the bases of walls.

\footnotetext{
${ }^{96}$ Kaplan and Ritter-Kaplan 1993, 656.

${ }^{97} \mathrm{Kemp} 2000,88$.
}

Atop these stone foundations, the mudbrick superstructure of the towers was constructed (L.3003, 3103). The orange-yellow brickwork (L.3003; brick dimensions of $45 \times 45 \times 12 \mathrm{~cm}$ ) preserved in the southern tower to more than $3 \mathrm{~m}$ above the passageway's surface was first identified by Kaplan on the south side of the passageway. ${ }^{98}$ In 2013, remains of the earliest bricks of the northern tower (L.3103), which were of identical composition and color, were also traced from north to south below red bricks from a later building phase, revealing that the lowest story of the earliest gate towers (i.e., RG-4b) was originally entirely constructed of mudbricks of a homogenous type and composition. As suggested by other studies of brick colors, the sandy color and absence of artifacts within the phase RG-4b bricks indicate that their material was obtained from a sandy context away from the mound itself. ${ }^{99}$ The brick composition also did not include temper, which is typical of mudbrick composition in Egypt, as, for example, at Amarna. ${ }^{100}$ This situation is distinct from subsequent repairs and constructional phases of the gate in which some bricks contained ash originating from occupational debris. The gate's layout as defined by the surviving brickwork and its stone foundations centered on two nearly rectangular mudbrick towers, the footprints of which averaged $22.35 \mathrm{~m}$ long $\times 6.2 \mathrm{~m}$ wide. ${ }^{101}$ The western end of the southern tower also preserved a corner that indicates that the RG- $4 b$ gate's towers were rabbeted (see fig. 16).

The RG-4b towers were separated by a $4 \mathrm{~m}$ wide passageway with an almost level surface, which narrowed by a half meter at its western end (see fig. 16). No artifacts, occupational debris, or floor could be associated with this phase owing to the construction of the later gate. It appears these and any collapsed remains were removed during rebuilding efforts. However, Kaplan identified a capped drain lined with cobbles (L.3168 [L.3192]) running under the floor of the passageway, as seen in the section drawing (see fig. 5). ${ }^{102}$ None of the capping was encountered during the 2013 excavations of the RG-4a destruction debris, however, suggesting that the drain was no longer

\footnotetext{
${ }^{98}$ This feature is identified with W.152, which was excavated by Tel Aviv University in 1999 (Herzog 2008, 1791).

${ }^{99}$ Burke 2008, 73-4.

${ }^{100}$ Kemp 2000, 81-2.

${ }^{101}$ Cf. Kaplan's $(1956,260)$ measurement of only $18 \mathrm{~m}$; see also Herzog 2008, 1791.

${ }^{102}$ The drain was also encountered during Tel Aviv University's excavations (Herzog 2008, 1791).
} 


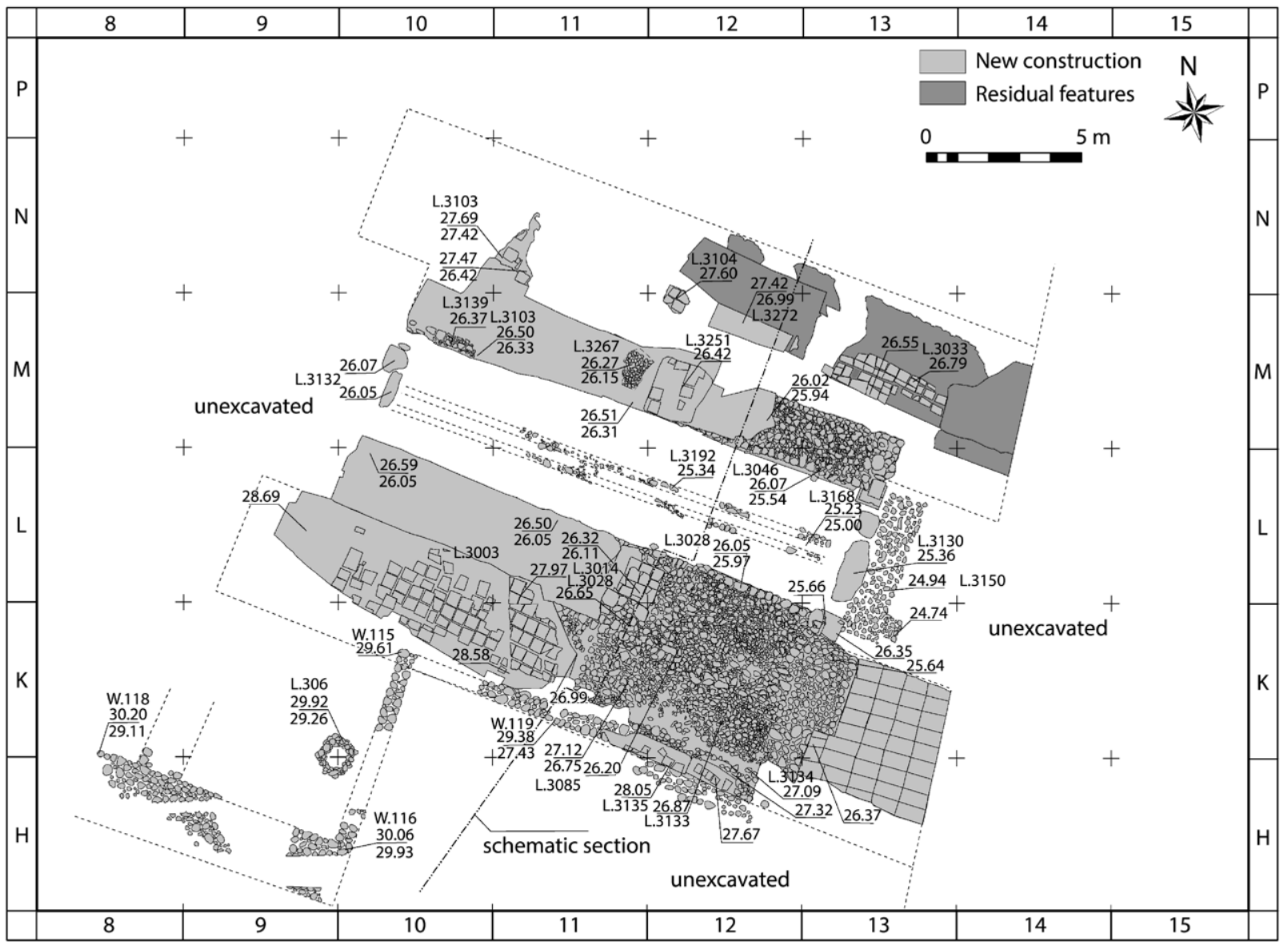

FIG. 16. Plan of Area A, phase RG-4b gate complex, showing probable contemporaneous structures of level V to the south of the gate (drawing by K. Kowalski). All numbers with decimals indicate elevations (masl).

in use during the following phase. Both ends of the gate revealed large limestone slabs used as thresholds (L.3130, 3132), which based on the stone type were brought from off-site, likely from a streambed. On the east, outside the fortress gate, the road surface consisted of a cobble bedding that was traced by Kaplan for $8 \mathrm{~m}$ from the gate's eastern threshold down the eastern slope of the mound (see fig. 9). ${ }^{103}$ This feature was re-exposed during the 2013 excavations.

The RG-4b gate, as described above, can be distinguished from the rebuilt RG-4a gate based on several lines of evidence. First, the remains of the RG- $4 b$ brickwork are irregularly preserved along their interface with the later brickwork of RG-4a, revealing signs of erosion of an earlier structure that suggest that the entirely different brickwork of RG-4a constitutes an

\footnotetext{
${ }^{103}$ Kaplan 1956, 260.
}

attempt to salvage and rebuild the earlier gate's superstructure. At the western end of the northern tower a thin layer of sand (L.3195) on top of the yellow bricks of RG-4b suggests a gap in time before the rebuilding of the gate. Second, because of the eroded condition of the RG-4b brickwork, it was coated with a lime plaster prior to the addition of RG-4a brickwork. These plaster layers were identified during renewed excavations in both the northern and southern towers (L.3203, 3114). Finally, the dark-red brickwork with black mud mortar of the RG-4a phase (L.3205, 3083 [L.3084]), which was encountered by Kaplan, as evidenced by the original section drawing (see fig. 5), could be clearly distinguished from the earlier gate's brickwork during the excavation (see fig. 17). The color and composition of the later bricks and the use of black mud, which was evidently poured between the red brick additions to provide a foundation for the new bricks, make the later repairs distinct from the sandy orange bricks of 


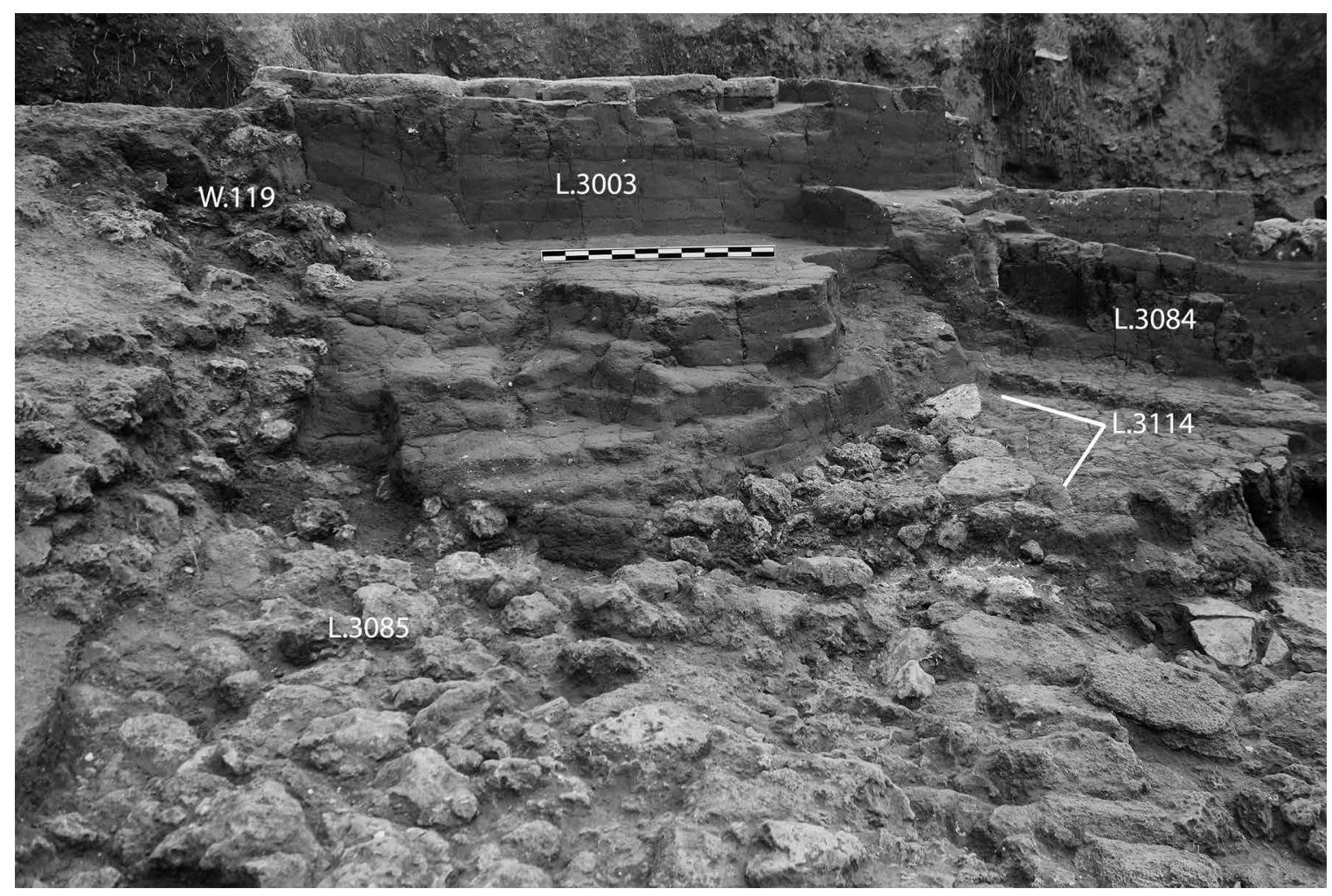

FIG. 17. Southern mudbrick tower (L.3003) of phase RG-4b gateway. Arrows point to plaster (L.3114) separating phase RG4a additions (L.3083 [L.3084]), view to the west-northwest (JCHP photograph 2012-P0922).

the RG-4b gate. Together these lines of evidence reveal $\mathrm{RG}-4 \mathrm{~b}$ to have been a separate, earlier gate construction that was substantially damaged after having been left exposed, requiring rebuilding — a more complicated picture than Kaplan's identification of these mudbrick features as part of a single-phase gate (i.e., level IVB). The circumstances behind the end of the $\mathrm{RG}-4 \mathrm{~b}$ gate remain unclear.

Unfortunately, in the absence of in situ finds on a floor or material culture recovered from the brickwork, the precise dating of the RG- $4 \mathrm{~b}$ gate's construction is based on its relative stratigraphic position. As noted above, the construction of the RG-4b gate appears to have occurred after the destruction of level VI late but before the RG-4a gate (i.e., level IVB) was built. Therefore, it seems likely that the RG-4b gate was contemporaneous with the level V remains to the south of the gate (see fig. 16). Without evidence of a gap in occupation after level VI late, these observations point toward a start date during the transition between the LB IB and LB IIA, ca. 1400 B.C.E., for phase RG-4b. The gate's rebuilding then occurred at the time of the construction of Kaplan's level IVB gate, which is associated with Ramesses II.
Phase RG-4a: The Gate of Ramesses II

The RG-4a gate was rebuilt, adhering to the RG-4b gate's layout (fig. 18). The construction of the RG-4a gate began with the removal of debris from the gate's passageway that not only eradicated traces of RG-4b occupational debris (and possibly the accompanying destruction debris) but also removed traces of the presumed beaten-earth road surface belonging to the $\mathrm{RG}-4 \mathrm{~b}$ gate. This eradication of the gate floor is not surprising given the manner in which the gate area was so extensively prepared for the RG- $4 \mathrm{~b}$ gate's construction. The restoration work of phase RG-4a is particularly clear in brickwork of the southern tower, which preserves a checkerboard-like pattern of red bricks and brown to black clay fills, which were often poured between the new bricks and the uneven brick remains of the RG- $4 \mathrm{~b}$ towers. Mudbrick construction of the gate's southern tower (L.3083 [L.3084]; brick dimensions $40 \times 37 \times 12 \mathrm{~cm}$ ) reveals continued adherence to Egyptian practices, including sand used for temper without straw and limited use of mortar. ${ }^{104}$ Similarly, phytolith

\footnotetext{
${ }^{104}$ Kemp 2000, 81-2.
} 


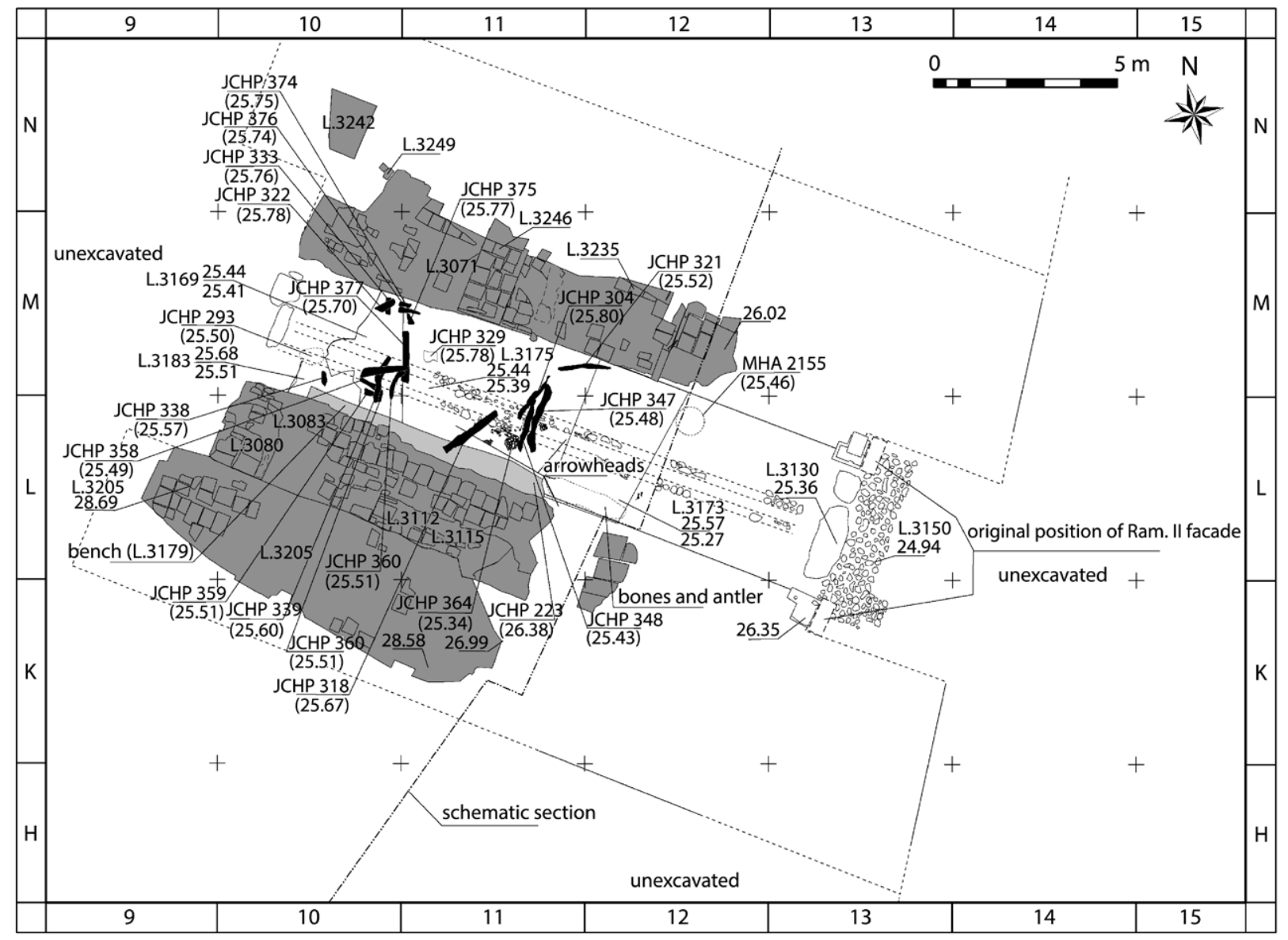

FIG. 18. Phase RG-4a (level IVB) gate complex plan, showing in situ finds from the lowest levels of the destruction debris (drawing by K. Kowalski). All numbers with decimals indicate elevations (masl).

layers, likely the remains of grass beds or reed matting laid between some brick layers during construction, reveal another Egyptian building tradition. ${ }^{105} \mathrm{~A}$ bench, curb, or possible buttress (L.3179; see fig. 18) was also added along the southern side along the central portion of the passageway in this phase (with possible traces on the northern side, L.3201).

This phase of the gate's construction was evidently adorned with the monumental facade of Ramesses II, which was excavated by Kaplan and served as the basis for the dating of the level IVB gate, as discussed above (see table 4). The facade's full dimensions were reconstructed by the JCHP, including the placement of several additional fragments (see fig. 8). The dimensions are of particular significance in light of the timbers recovered from the RG-4a destruction debris. If the passageway itself was as high as the stone facade, which likely supported a wooden lintel, then its interior was

\footnotetext{
${ }^{105}$ Kemp 2000, 91.
}

at least $4.15 \mathrm{~m}$ high. Such a figure comports well with the height of the solid mudbrick towers along the passageway. The remains of the mudbrick superstructure (L.3205), which was preserved to a higher elevation at the time of Kaplan's excavations, suggest that the solid towers of the RG-4a gate's lower story had a minimum elevation of $4.5 \mathrm{~m}$ from the floor of the passageway to the top of the mudbrick. This height also correlates with the mudbrick surface that was encountered by Kaplan to the south of the southern tower, at an elevation of approximately 30 masl (see fig. 5, at left). Although this surface is not discussed in his reports and could not be dated by finds from his excavations, its elevation indicates that the second story of the RG-4a gate complex could be accessed from ground level on the southern side of the gate. In 2014, work within the Lion Temple to the west of the gate confirmed that a slope rose from the western end of the gate around the southern tower up to the south side of the gate complex, revealing how the difference in elevation between these areas was negotiated. Together these observations vindicate 
Kaplan's initial, if surprising, claim that the original gate (i.e., phase RG-4b) was "dug deep into the eastern part of the ruined citadel." ${ }^{106}$ Kaplan's assignment of the inscribed fragments of the facade of Ramesses II to the level IVB gateway was confirmed based on the elevation provided for one of the facade fragments (MHA 2156) that originated from within the leveling operation for the construction of the level IVA gate (i.e., RG-3b, discussed below).

The phase RG-4a gate is the best preserved of the gate's phases (fig. 19). This preservation is due to both its burial and the lack of disturbance of the destruction debris after its deposition. Excavations in 2012 and 2013 exposed the RG-4a gate's destruction debris, which was approximately $1.5 \mathrm{~m}$ deep along more than $10 \mathrm{~m}$ of the gate's passageway. ${ }^{107}$ This debris was sealed by the northward collapse of 20 courses of the northern elevation of the southern tower (L.3102; see fig. 5 ), which remained in articulation with their original bonding. Portions of these mudbricks and other parts of the destruction debris that came into contact with burning timbers reveal stages in the gate's destruction, which seem to have been part of a sequence of deliberate efforts to make the massive structure unusable after its destruction. The excavation of this destruction debris in 2013 revealed that the ceiling and its structural supports collapsed first, directly onto the passageway floor. Before those timbers were fully burned, they were buried below mudbrick debris from the collapse of the second story (fig. 20). This debris was sealed when first the upper part of the north tower and then the upper part of the south tower were knocked down. There was, however, only limited damage to the solid mass of the mudbrick towers at ground level. The fires burned so hot at the outset of the destruction that in the lowest courses of the towers' mudbrick superstructures all the bricks facing the passageway were fired in situ to an orange-red color before being buried by the collapse of the second story. ${ }^{108}$ The evidence suggests that the destruction was not the product of an accidental fire but rather a process requiring a series of steps. ${ }^{109}$

\footnotetext{
${ }^{106}$ Kaplan and Ritter-Kaplan 1993, 656.

${ }^{107}$ Herzog $(2008,1791)$ also encountered this destruction, and both he and Kaplan dated it to the reign of Ramesses II (i.e., LB IIB).

${ }^{108}$ Samples of burned bricks were taken from both the northern and southern towers for compositional analysis by Mara Page, University of Washington.

${ }^{109}$ Kaplan $(1972,80)$ reached a similar conclusion.
}

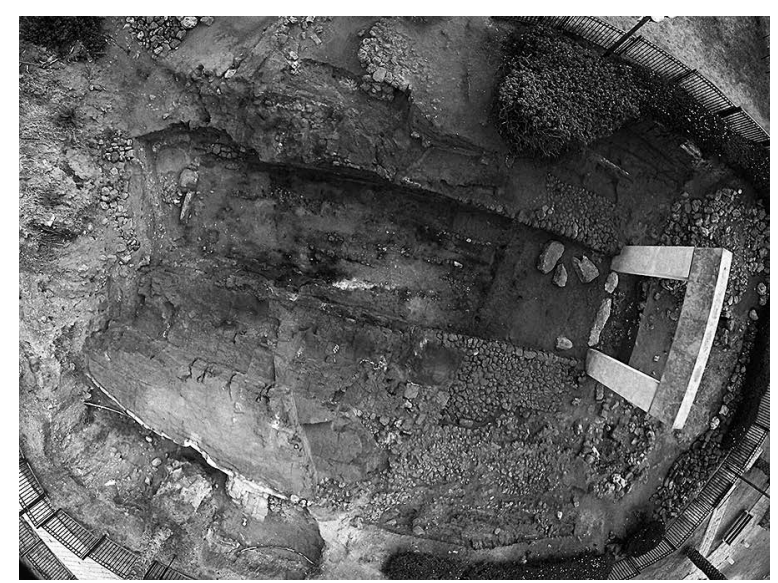

FIG. 19. Aerial view of the phase RG-4a gate (level IVB) following 2013 excavations (JCHP photograph 2013-P0525). North is at the top of the photograph. Boulders within the eastern part of the passageway are remains of the level IVA threshold left by Kaplan. Note the concrete reconstruction by the Israel Antiquities Authority of the Ramesses II facade from the 1990s, at right.

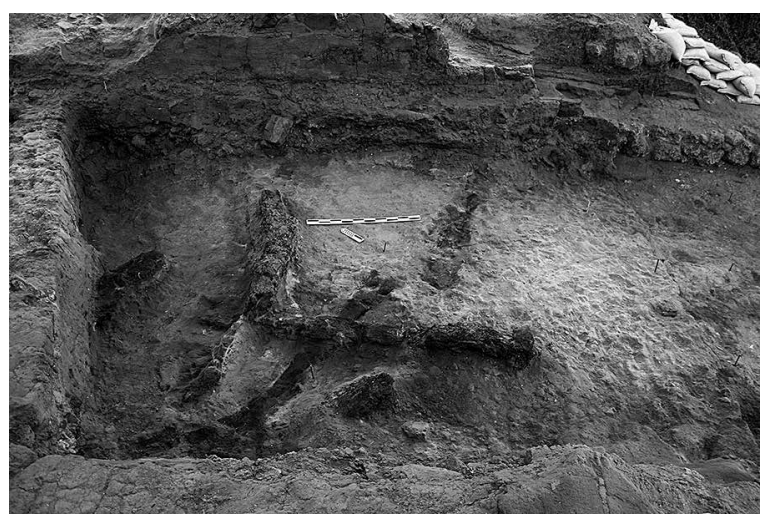

FIG. 20. Timbers (JCHP 277, 318, 278, 284, and 282) within the phase RG-4a (level IVB) destruction debris (L.3108, 3146, and 3157), view to the north (JCHP photograph 2013-P0539).

The 2013 excavations also provided extensive evidence for the gate's function prior to its destruction. The floor of the gate's passageway was encountered below the destruction debris that originated not only from the collapse of much of the passageway's interior elevations but also from the structural elements that roofed the passageway and were likely also the remains of the second story of the gate complex. Major finds on the floor included several arrowheads and a spearhead(?) (JCHP 300, 325, 327, and 344), a lead weight (JCHP 388), the antlers from at least 32 deer (JCHP 345), ${ }^{110}$ decorative ivory inlays (JCHP 295), thousands

\footnotetext{
${ }^{110}$ Identifications by Ed Maher, 2015.
} 
of seeds, ceramic vessels, and about two dozen timber beam and plank segments (see fig. 20) belonging to the gate's ceiling or upper story. While the arrowheads and spearhead may be indications of the battle to take the fortress prior to its destruction, the antlers that were strewn along the southern side of the passageway together with the vessels and seeds provide a glimpse into the role of the gate as a marketplace. The remains of these antlers included both whole and carefully cut portions, which reveal that a trade in antler tools and raw materials was conducted within the passageway. The beam and plank samples include cedar of Lebanon (Cedrus libani), oak (Quercus), and olive wood (Olea europaea) used in the construction of the gate's second story, roof, and flooring. ${ }^{111}$ These constitute the largest group of timbers successfully recovered from Late Bronze Age contexts in Israel to date. They will provide important chronological data concerning a terminus post quem for the construction of the gate complex and dates for repairs made to the building during its maintenance. ${ }^{112}$

The discovery of the timbers was given even greater chronological significance because of the destruction date furnished by the radiocarbon samples from thousands of seeds retrieved from the passageway floor below the destruction debris (fig. 21). Among the burned seeds are cereals such as barley (Hordeum vulgare) and wheat (Triticum dicoccum; durum/aestivum), olive pits (Olea europaea), grape pips (Vitis vinifera), chickpeas (Cicer arietinum), lentils (Lens culinaris), legumes (Lathyrus sativus), broad beans (Vicia faba), vetch (Fabaceae sativae) and pistachios (Pistacia). ${ }^{113}$ Such remains were unexpected in this context, given that monumental architecture rarely yields good evidence for the commensal practices of a site's inhabitants. These remains were recovered only directly from the surface, along the entirety of the passageway excavated in 2013; not a single seed was found within the thick destruction from the upper story, which buried

\footnotetext{
${ }^{111}$ Identifications by Brita Lorentzen (Dendrochronology Laboratory, Cornell University), 2014. Olive wood, acacia, and cedar samples were also identified by Nili Liphschitz, according to Herzog 2008, 1791.

${ }^{112} \mathrm{~A}$ project aimed at integrating radiocarbon dates from these charcoal samples and additional biological samples from the RG-4a gate is underway at the Laboratory for Aegean and Near Eastern Dendrochronology at Cornell University with Sturt Manning and Brita Lorentzen.

${ }^{113}$ Identifications by Andrea Orendi (Tübingen University), 2014.
}

the seeds. ${ }^{114}$ This indicates that these goods were not stored in containers in the upper story or on the roof. Furthermore, the quantity and conditions of the remains, because they showed no evidence of having been crushed, indicate that they were located in the gateway before the gate's destruction, in either sacks or baskets of which no traces could be identified. The patterns of deposition were also not random but rather consisted of collections of types (e.g., olive pits, wheat, chickpeas). Seeds and artifacts recovered within the gate indicate that the Egyptian gate was not an exclusively defensive structure but that it also likely served as an administrative center (second story), a storage space (second story), and possibly a market (passageway).

The ceramic assemblage for the phase RG-4a gate complex consists of a few vessels recovered by Kaplan and a larger group excavated during the 2013 season (fig. 22). Kaplan recovered only two vessels from the passage's eastern end that were associated with the destruction of the level IVB gate. These were a $1.5 \mathrm{~m}$ tall Cypriot pithos (MHA 2155; see figs. 10, 22), which was found smashed on the northern side of the passageway (at 25.76 masl; see fig. 5), and a lamp (MHA 2341; see fig. 22). In 2013, numerous fragments of simple bowls of Egyptian-style production (e.g., JCHP 292, 363, 390), large fragments of "Canaanite" transport amphoras (e.g., JCHP 251), a two-handled ovoid meat jar (JCHP 262) that is likely an import, ${ }^{115}$ and an imitation Mycenaean piriform jar ( JCHP 373) ${ }^{116}$ were recovered from the destruction debris (see fig. 22). Traditional dates for these vessels align with a 12thcentury B.C.E. context for this gate. Most of the bowls, the Cypriot pithos, and the imitation piriform jar were buried in situ on the floor under the destruction debris, while the remainder of the vessels appear to have fallen from the second story.

In 2012, an oversized steatite and faience scarab with the name of Amenhotep III (JCHP 223 at 26.38 masl; fig. 23), along with more than 800 small, cylindrical

\footnotetext{
${ }^{114}$ It is curious that neither of the previous expeditions mentions the collection of seeds from the floor of this gate.

${ }^{115}$ The best parallels for this form are found in Egypt (Aston and Pusch 1999, 45, 49-50, nos. 9, 70), as no parallels have been recovered from the Levant thus far (cf. Martin 2011, 71-2). Aston and Pusch $(1999,45)$ indicate a date range from the late 19th to the 21st Dynasty for this form.

${ }^{116}$ See Killebrew (2010, 106, fig. 4.10) for a parallel from Deir el-Balah as well as references to additional parallels at Lachish. See also Laemmel (2009, 178, fig. 20.4) for a comparable form at Tell el-Far'ah South (no. 936/21) and comparanda.
} 


\begin{tabular}{|c|c|c|c|c|c|c|c|}
\hline Phase & Locus & Lab Code & Material & $\delta^{13} \mathrm{C}$ & ${ }^{14} \mathrm{C}$ Age & $\begin{array}{c}\text { Individual Calibrated } \\
\text { Results }\end{array}$ & Modeled Results \\
\hline $\begin{array}{l}\text { Start } \\
R G-4 a\end{array}$ & & & & & & & $\begin{array}{l}1223-1190(27.8 \%) \\
1186-1159(19.8 \%) \\
1155-1130(47.8 \%)\end{array}$ \\
\hline RG-4a & 3175 & OxA-29559 & seed & -23.0 & $3011 \pm 29$ & $\begin{array}{c}1385-1340(12.3 \%) \\
1309-1188(75.5 \%) \\
1182-1158(3.9 \%) \\
1145-1129(3.7 \%)\end{array}$ & $\begin{array}{l}1215-1188(22.9 \%) \\
1182-1157(21.3 \%) \\
1147-1128(51.2 \%)\end{array}$ \\
\hline RG-4a & 3169 & OxA-29558 & seed & -22.9 & $2983 \pm 28$ & $\begin{array}{c}1369-1361(0.8 \%) \\
1289-1116(94.6 \%)\end{array}$ & $\begin{array}{l}1213-1187(22.3 \%) \\
1183-1156(22.1 \%) \\
1149-1127(51.0 \%)\end{array}$ \\
\hline RG-4a & 3170 & OxA-29283 & seed & -23.3 & $2980 \pm 28$ & $\begin{array}{c}1368-1362(0.5 \%) \\
1287-1114(94.9 \%)\end{array}$ & $\begin{array}{l}1212-1187(22.3 \%) \\
1183-1156(22.2 \%) \\
1148-1127(50.9 \%)\end{array}$ \\
\hline RG-4a & 3170 & UCIAMS-131642 & seed & -22.1 & $2975 \pm 15$ & $\begin{array}{c}1259-1242(7.6 \%) \\
1235-1153(68.9 \%) \\
1149-1127(18.9) \\
\end{array}$ & $\begin{array}{l}1213-1188(22.6 \%) \\
1182-1157(21.5 \%) \\
1147-1128(51.2 \%)\end{array}$ \\
\hline RG-4a & 3183 & UCIAMS-131640 & seed & -23.6 & $2970 \pm 20$ & $\begin{array}{c}1260-1240(6.9 \%) \\
1236-1121(88.5 \%)\end{array}$ & $\begin{array}{l}1212-1187(22.3 \%) \\
1183-1156(22.1 \%) \\
1148-1128(51.0 \%)\end{array}$ \\
\hline RG-4a & 3170 & UCIAMS-131644 & olive pit & -23.6 & $2970 \pm 15$ & $\begin{array}{c}1257-1248(2.8 \%) \\
1232-1126(92.6 \%)\end{array}$ & $\begin{array}{l}1212-1188(22.4 \%) \\
1182-1157(21.9 \%) \\
1147-1128(51.1 \%)\end{array}$ \\
\hline RG-4a & 3175 & UCIAMS-131649 & cereal & -22.8 & $2970 \pm 15$ & $\begin{array}{c}1257-1248(2.8 \%) \\
1232-1126(92.6 \%)\end{array}$ & $\begin{array}{l}1212-1188(22.3 \%) \\
1182-1157(21.8 \%) \\
1147-1128(51.2 \%)\end{array}$ \\
\hline RG-4a & 3170 & UCIAMS-131648 & seed & -23.3 & $2965 \pm 15$ & $\begin{array}{c}1255-1253(0.3 \%) \\
1230-1122(95.1 \%)\end{array}$ & $\begin{array}{l}1212-1187(22.3 \%) \\
1183-1156(22.3 \%) \\
1148-1128(50.8 \%)\end{array}$ \\
\hline RG-4a & 3169 & UCIAMS-131638 & olive pit & -21.9 & $2965 \pm 15$ & $\begin{array}{c}1255-1253(0.3 \%) \\
1230-1122(95.1 \%)\end{array}$ & $\begin{array}{l}1212-1187(22.2 \%) \\
1183-1156(22.3 \%) \\
1148-1128(50.9 \%)\end{array}$ \\
\hline RG-4a & 3170 & UCIAMS-131645 & olive pit & -22.9 & $2955 \pm 20$ & $\begin{array}{c}1258-1247(1.2 \%) \\
1232-1109(92.7 \%) \\
1099-1087(1.3 \%) \\
1062-1059(0.3 \%) \\
\end{array}$ & $\begin{array}{l}1210-1186(21.9 \%) \\
1183-1156(22.7 \%) \\
1149-1127(50.7 \%)\end{array}$ \\
\hline RG-4a & 3169 & UCIAMS-131637 & seed & -22.9 & $2945 \pm 20$ & $\begin{array}{c}1220-1106(87.7 \%) \\
1103-1073(6.0 \%) \\
1065-1056(1.7 \%) \\
\end{array}$ & $\begin{array}{l}1210-1156(45.0 \%) \\
1150-1127(50.4 \%)\end{array}$ \\
\hline RG-4a & 3183 & UCIAMS-131641 & seed & -23.2 & $2945 \pm 15$ & $\begin{array}{c}1218-1109(93.1 \%) \\
1099-1087(1.8 \%) \\
1063-1058(0.5 \%) \\
\end{array}$ & $\begin{array}{l}1209-1185(21.9 \%) \\
1183-1156(23.0 \%) \\
1150-1127(50.4 \%)\end{array}$ \\
\hline RG-4a & 3175 & UCIAMS-131643 & olive pit & -22.6 & $2940 \pm 20$ & $\begin{array}{c}1215-1071(92.8 \%) \\
1066-1056(2.6 \%) \\
\end{array}$ & $\begin{array}{l}1209-1156(45.1 \%) \\
1150-1127(50.3 \%)\end{array}$ \\
\hline RG-4a & 3169 & UCIAMS-131639 & seed & -23.3 & $2940 \pm 15$ & $\begin{array}{c}1214-1108(89.2 \%) \\
1101-1077(4.8 \%) \\
1064-1057(1.3 \%) \\
\end{array}$ & $\begin{array}{l}1209-1156(45.2 \%) \\
1150-1127(50.2 \%)\end{array}$ \\
\hline RG-4a & 3175 & UCIAMS-131647 & seed & -21.4 & $2940 \pm 15$ & $\begin{array}{c}1214-1108(89.2 \%) \\
1101-1077(4.8 \%) \\
1064-1057(1.3 \%) \\
\end{array}$ & $\begin{array}{l}1209-1156(45.2 \%) \\
1150-1127(50.2 \%)\end{array}$ \\
\hline RG-4a & 3170 & UCIAMS-131646 & seed & -23.4 & $2935 \pm 15$ & $\begin{array}{c}1210-1106(83.3 \%) \\
1103-1072(9.4 \%) \\
1066-1056(2.7 \%) \\
\end{array}$ & $\begin{array}{l}1209-1156(45.1 \%) \\
1150-1127(50.3 \%)\end{array}$ \\
\hline $\begin{array}{l}\text { Transition } \\
R G-4 a / 3 b\end{array}$ & & & & & & & $\begin{array}{l}1205-1183(16.2 \%) \\
1178-1150(23.0 \%) \\
1144-1122(56.2 \%)\end{array}$ \\
\hline $\begin{array}{l}\text { Transition } \\
R G-3 b / 3 a\end{array}$ & & & & & & & $\begin{array}{c}1194-1180(5.8 \%) \\
1169-1095(89.6 \%)\end{array}$ \\
\hline RG-3a & 3236 & UCIAMS-159338 & wheat seed & -23.1 & $2935 \pm 15$ & $\begin{array}{c}1210-1106(83.3 \%) \\
1103-1072(9.4 \%) \\
1066-1056(2.7 \%) \\
\end{array}$ & $\begin{array}{c}1191-1177(5.0 \%) \\
1163-1142(10.7 \%) \\
1134-1076(79.8 \%) \\
\end{array}$ \\
\hline RG-3a & 3029 & UCIAMS-159336 & wheat seed & -23.6 & $2935 \pm 15$ & $\begin{array}{c}1210-1106(83.3 \%) \\
1103-1072(9.4 \%) \\
1066-1056(2.7 \%)\end{array}$ & $\begin{array}{c}1191-1177(5.0 \%) \\
1163-1142(10.7 \%) \\
1134-1076(79.7 \%)\end{array}$ \\
\hline RG-3a & 3016 & UCIAMS-159334 & wheat seed & -24.0 & $2920 \pm 15$ & $\begin{array}{c}1207-1201(1.1 \%) \\
1196-1142(27.1 \%) \\
1133-1047(67.2 \%) \\
\end{array}$ & $\begin{array}{c}1191-1178(4.9 \%) \\
1161-1144(9.7 \%) \\
1132-1074(80.8 \%)\end{array}$ \\
\hline RG-3a & 3236 & UCIAMS-159339 & wheat seed & -23.5 & $2915 \pm 15$ & $\begin{array}{c}1194-1143(18.7 \%) \\
1132-1036(76.5 \%) \\
1033-1031(0.2 \%) \\
\end{array}$ & $\begin{array}{c}1191-1178(4.9 \%) \\
1161-1144(9.4 \%) \\
1132-1073(81.1 \%)\end{array}$ \\
\hline RG-3a & 3038 & UCIAMS-159337 & wheat seed & - & $2910 \pm 20$ & $\begin{array}{l}1193-1143(16.1 \%) \\
1131-1018(79.3 \%)\end{array}$ & $\begin{array}{c}1191-1178(4.9 \%) \\
1161-1144(9.4 \%) \\
1132-1071(81.1 \%)\end{array}$ \\
\hline End $R G-3 a$ & & & & & & & $\begin{array}{c}1189-1175(4.3 \%) \\
1159-1140(8.4 \%) \\
1129-1047(82.7 \%)\end{array}$ \\
\hline
\end{tabular}

FIG. 21. Radiocarbon dates from Jaffa and modeled results for samples from phases RG-4a and RG-3a. 


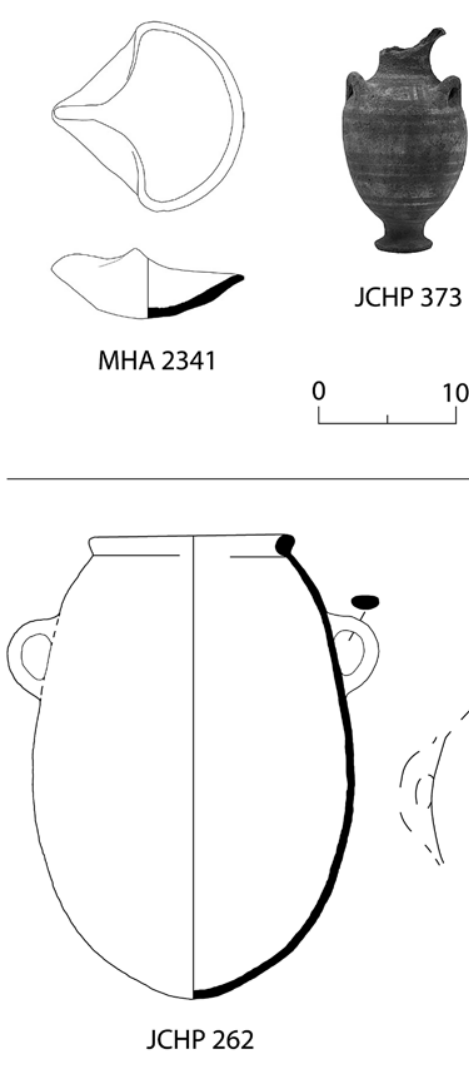

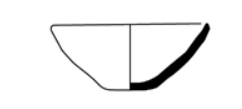

JCHP 363

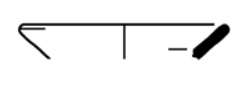

JCHP 390

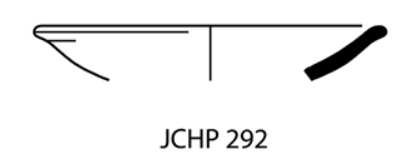

JCHP 292

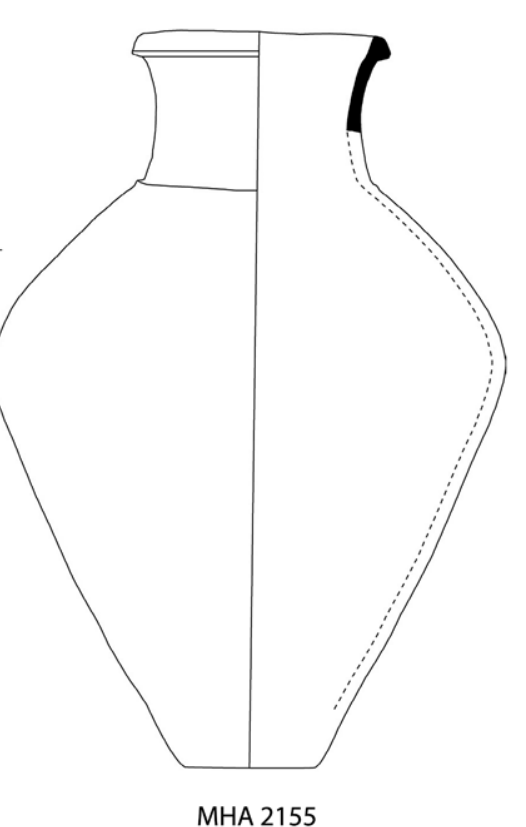

FIG. 22. Ceramics from destruction debris of the phase RG-4a (level IVB) passageway: lamp (MHA 2341); imitation Mycenaean piriform jar (JCHP 373); Egyptian-style simple bowls (JCHP 292, 363, 390); Late Cypriot pithos (MHA 2155); “Canaanite” transport amphora (JCHP 251); imported(?) Egyptian two-handled ovoid meat jar (JCHP 262).

beads of various materials, ${ }^{117}$ a smaller steatite scarab also with Amenhotep III's name (JCHP 224; see fig. 5), and various fragments of horn (JCHP 249), were recovered from a space (L.3100) created when the northern face of the southern tower collapsed into the passageway. Owing to the absence of any other finds within this locus, these elements appear to constitute a complete necklace (fig. 24) and ring that may have belonged to an official resident at the Egyptian fortress. The discovery of these items provides further context for two additional scarabs of Amenhotep III exposed in the Ramesses Gate by Tel Aviv University in 1999. The first is a medium-sized scarab of Amenhotep III (TAU $528 / 80$ ) that is described as having been "incorporated into the reddish brick of the original phase of the gate." ${ }^{18}$ Our own excavations of the western extension of this context suggest, however, that this scarab was

\footnotetext{
${ }^{117}$ The beads were collected in several lots (JCHP 216, 227, 232, and 234).

${ }^{118}$ TAU 528/80 is from L.171 (Sweeney 2003, 54, 59; see also Herzog 2008).
}

likely recovered from the same deposit amid the collapsed bricks, as were the beads and scarab described above, as no material culture was evident within the RG-4a brickwork. ${ }^{119}$ This clarification of the context for the Tel Aviv University scarab suggests its identification as a second ring belonging to the same individual to whom also belonged the ring and necklace recovered in 2012. ${ }^{120}$

\footnotetext{
${ }^{119}$ Because the Tel Aviv University expedition and Kaplan's excavations each found scarabs embedded in mudbricks, JCHP staff processed every brick during the removal of the brickwork in each phase. However, no artifacts and very few sherds were recovered during this effort.

${ }^{120}$ Other inscribed material from the reign of Amenhotep III in Jaffa includes a scarab belonging to his wife, Tiy (MHA 4327), which was recovered by Kaplan from the floor of the so-called Lion Temple. The temple has been identified by the JCHP excavations as contemporary with the phase RG-4a gate complex (Kaplan and Ritter-Kaplan 1993, 658; see also Herzog 2008, 1791). The Tel Aviv University excavations recovered a second scarab from the reign of Amenhotep III, a Lion Hunt scarab, albeit one found in a secondary context within the gray bricks of the next gate (i.e., RG-3b) (Sweeney 2003). This find,
} 


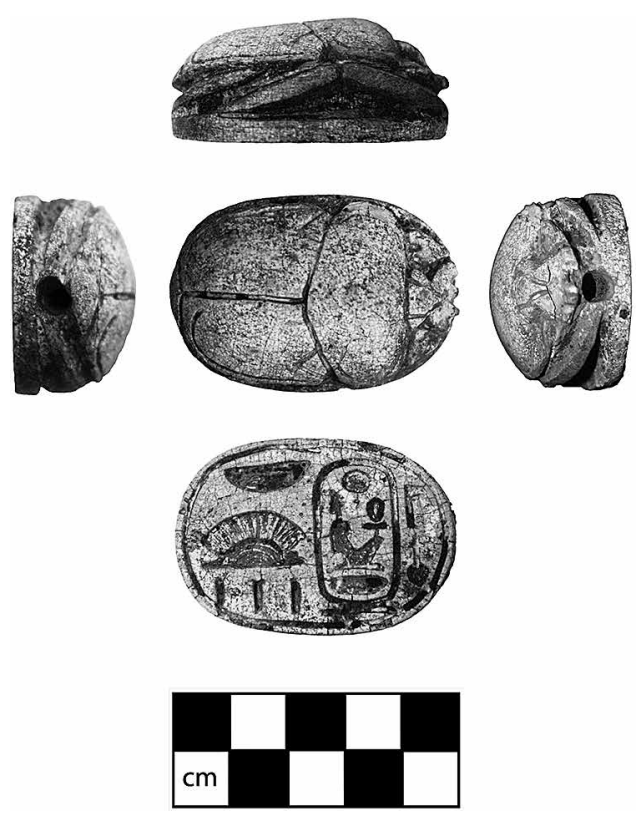

FIG. 23. Large Egyptian scarab (JCHP 223) of Amenhotep III recovered from phase RG-4a (level IVB) destruction.

\section{Phase RG-3b: The Late Ramesside Gate}

There is no evidence above the RG-4a destruction debris to indicate a period of significant abandonment before the start of phase RG-3b, when the gate was rebuilt. The construction of the RG-3b gate began with a raking of the destruction debris of the RG-4a gate and the deposition of various slurries of brown and red mud (L.3056 and L.3061; see fig. 5) that were poured over the debris to level it. This was suggested by the density of these deposits and the sagging of these layers in the center of the passageway. None of these layers, however, exhibited signs of functioning as surfaces, and no artifacts were recovered from them except for small, water-worn ceramic sherds. These thick layers of mud would have required an enormous quantity of water to produce. In the midst of the leveling process, however, various thin laminations of windblown and water-lain sand and clay also accumulated. Although subtle, this evidence may indicate that the gate was constructed not during summer but possibly during the fall. ${ }^{121}$

taken together with the context of the Amenhotep III scarabs from the phase RG-4a destruction debris, reveals that inscribed scarabs in Jaffa are, thus far, predominately associated with this pharaoh.

${ }^{121}$ If there had been greater evidence for precipitation, such as irregular erosion of the mud layers, it might have been suggested that the reconstruction took place during the winter.

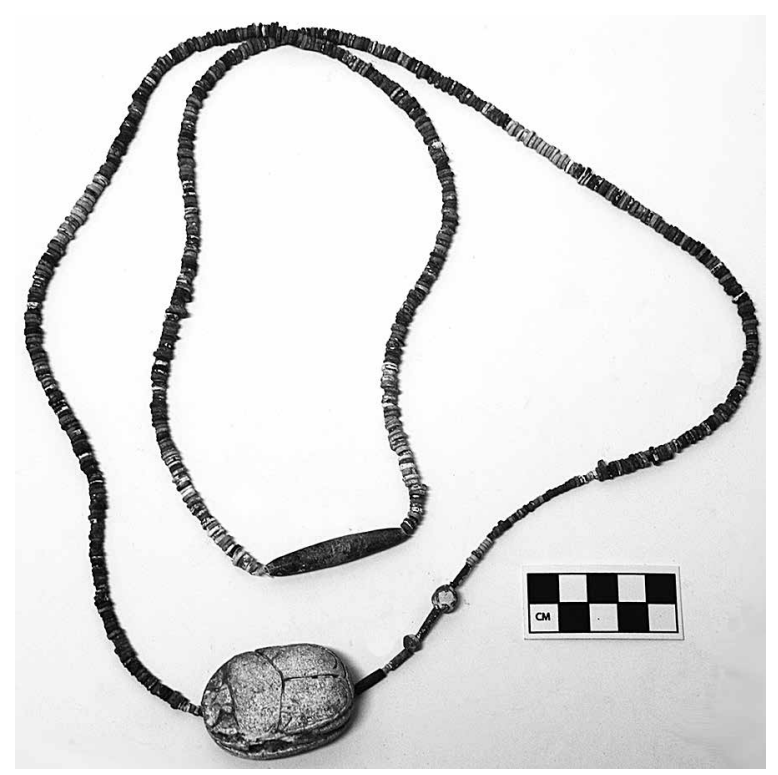

FIG. 24. Necklace reconstructed from more than 500 small beads, large scarab (JCHP 223), and various other beads and elements (JCHP 216, 224, 227, 232, and 234) found in L.3100 of the phase RG-4a (level IVB) destruction.

Based on the stratigraphy encountered during JCHP excavations, as with Kaplan's level IVB gate, two distinct phases were also identified for the level IVA gate: RG-3b and RG-3a (see table 4). The plan of the RG-3b gate (Kaplan's level IVA) was identical to that of the RG-4a gate but $2 \mathrm{~m}$ above the lowest brick courses of the RG-4a gate and atop the leveling layers described above (fig. 25). ${ }^{122}$ The restored walls on both sides of the passageway were rebuilt with gray bricks (L.3020 [L.3022]; $45 \times 20 \times 12 \mathrm{~cm})^{123}$-indicating use of occupational and destruction debris with a high ash content in the production of the brickswhile the remainder of the gate's towers reused the RG-4a remains as their foundation (fig. 26). ${ }^{124}$ The new gate's roadway was supported by a thick foundation of boulders, cobbles, and pebbles (L.3011) taken from the seashore, laid atop the leveling mud layers, and covered with a layer of compact earth. One fragment of the Ramesses II facade recovered by Kaplan

\footnotetext{
However, there was no evidence to indicate erosion typical of heavy winter rains.

${ }^{122}$ Also noted by Kaplan and Ritter-Kaplan 1993, 656.

${ }^{123}$ We have equated the gray bricks of L.3020 (L.3022) with W.162, which was excavated by Tel Aviv University (Herzog 2008, 1792).

${ }^{124}$ Kaplan 1972, 81.
} 


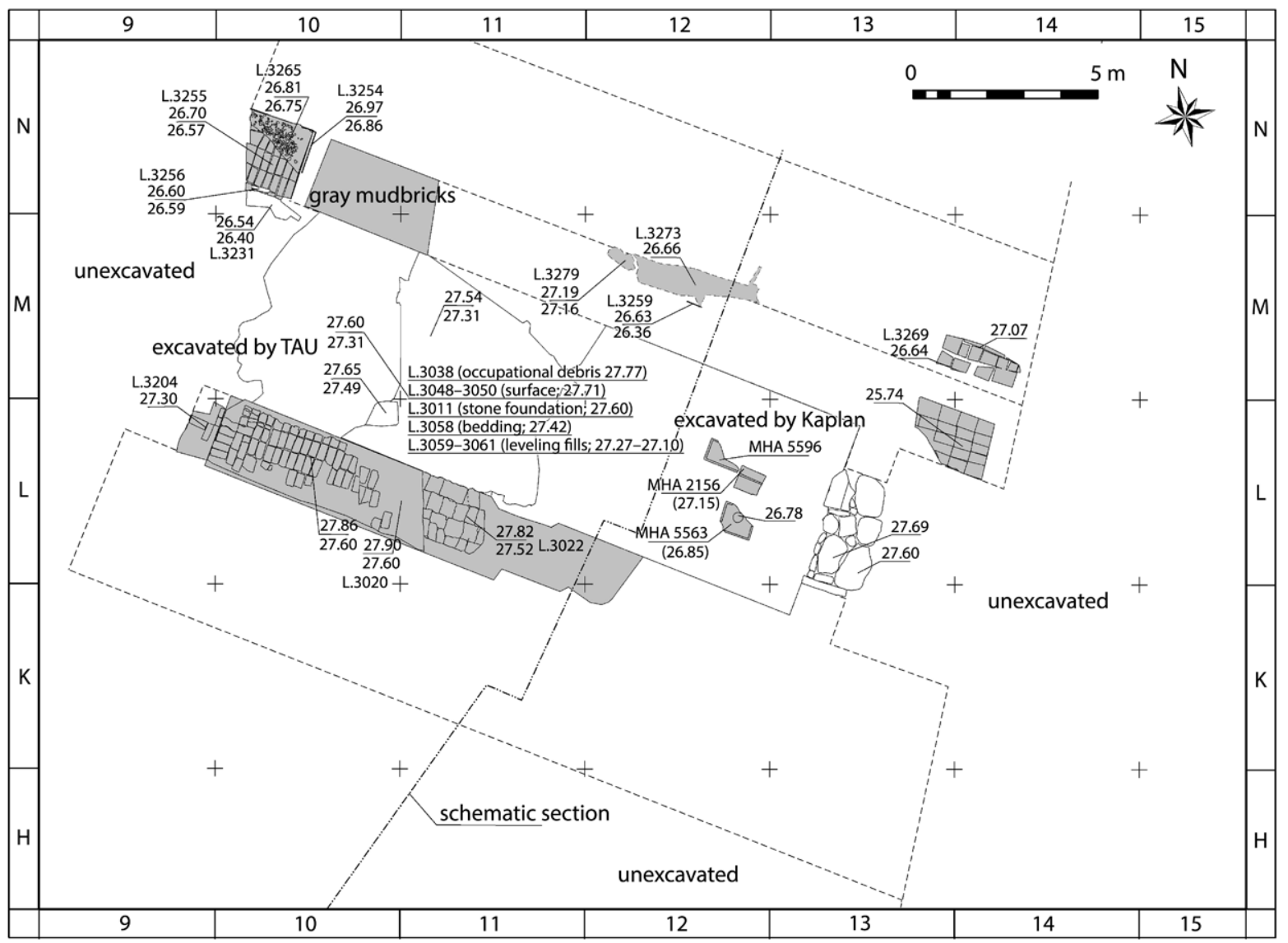

FIG. 25. Plan of Area A, RG-3b (level IVA) gate complex. Note that features belonging to the northern half of the RG-3b gate were excavated only by Kaplan (drawing by K. Kowalski). All numbers with decimals indicate elevations (masl).

(MHA 2156) was buried in the leveling fill beneath the gate's floor (see fig. 25). ${ }^{125}$

Because of the limited remains of the RG-3a gate left to excavate, ${ }^{126} 100 \%$ of the matrix of this floor's occupational debris, the surface composition, and its foundation were sieved. Although few artifacts were recovered from among the stones, a small, enstatite amuletic scarab revealed that the quantities of Aegyptiaca were sufficiently high at Jaffa by the second half of the Late Bronze Age to appear within fills (fig. 27; JCHP 225). ${ }^{127}$

\footnotetext{
${ }^{125}$ Oren Ackerman (Bar Ilan University) identified the components of the subfloor (L.3011) as originating from the sea rather than a wadi.

${ }^{126}$ When the JCHP began excavations in 2011, an "isthmus" of stratigraphy associated with the level IVA gate connected the northern and southern towers of the gate complex (see area of L.3011 in fig. 26). This sequence was preserved immediately below a large Persian-period wall (W.3). Consequently, considerable caution was taken to document this stratigraphy in the highest resolution possible.

${ }^{127}$ According to K.V.L. Pierce, the inscription simply reads
}

This seemingly straightforward fact is of concern owing to the absence of small finds such as scarabs among the collection of artifacts from Kaplan's excavations, despite his claim to have recovered "numerous scarabs and faience fragments" during the 1956 season. ${ }^{128}$

\section{Phase RG-3a: The Final Phase of the Ramesside Gate}

Phase RG-3a constitutes repairs made to the RG-3b gate during the late 12 th century B.C.E. (fig. 28). This phase was not identified during excavations of level IVA by Kaplan or Herzog (see table 4). The restoration of the RG-3b gate included the addition of a row of gray mudbricks (L.3052) against the damaged northern elevation of the southern tower (L.3022), including a haphazard mess of gray bricks behind this row, which is similar to the repairs that were carried out

\footnotetext{
"Maat is a god" or "the god is just." For parallels, see cowroid no. 173 and scaraboid no. 175 in Teeter and Wilfong 2003.

${ }^{128}$ Kaplan 1956, 260.
} 


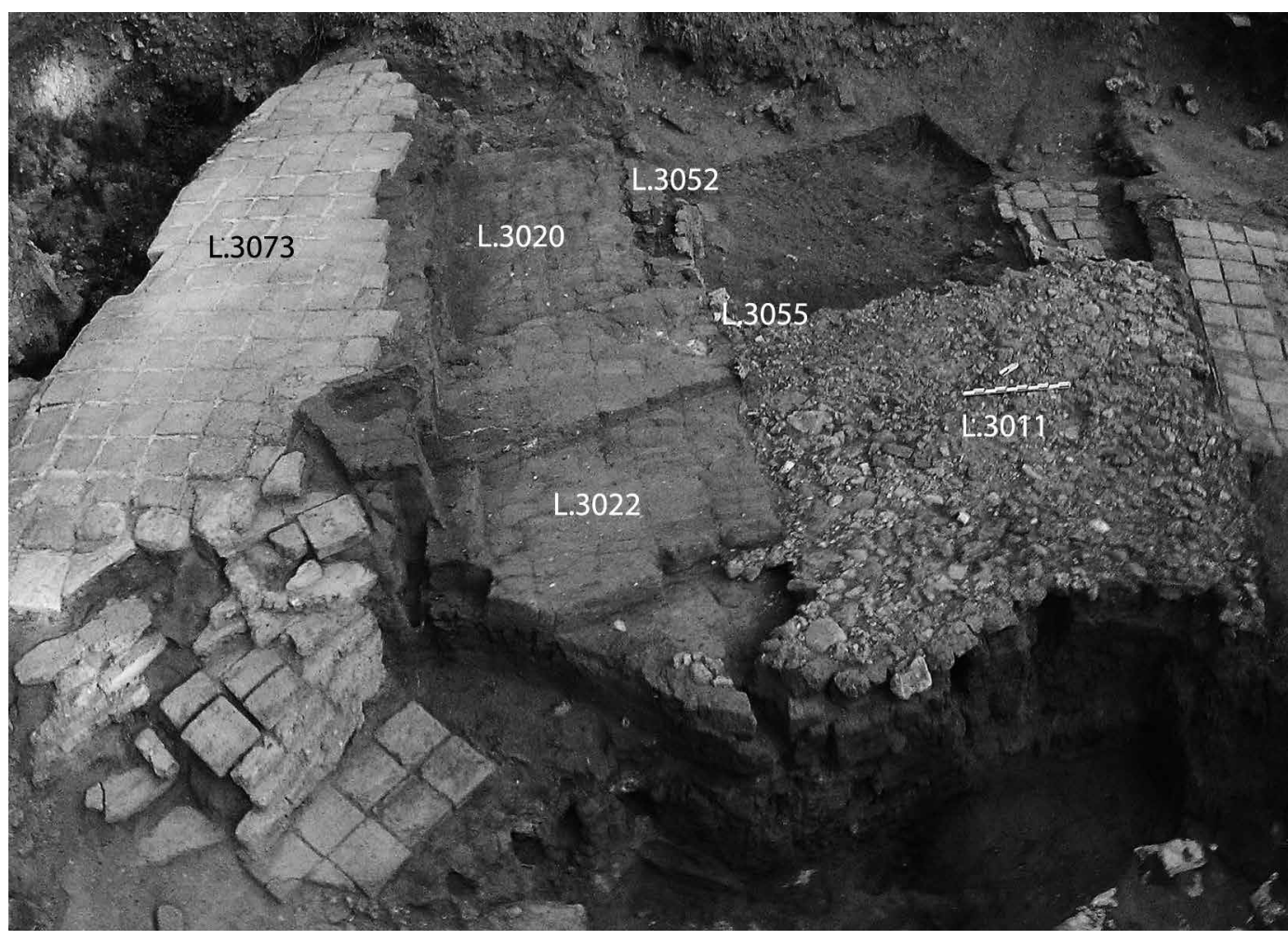

FIG. 26. RG-3b gate and stone subfloor of passageway (L.3011), including RG-3a restoration (L.3052), view to the southwest. Both phases were conflated as level IVA by Kaplan (JCHP photograph 2012-P0035).

on the RG-4a gate (fig. 29). The RG-3a repairs were more difficult to discern than those of phase RG-4a, since identical gray bricks and gray mortar were used in both RG-3b and RG-3a; however, the brick additions (L.3052) of phase RG-3a clearly represent a later modification. Kaplan made the same observation but did not assign the additions to a different phase (see fig. 5). The RG-3a additions, like the RG-4a repairs, were separated from earlier construction by a thin vertical layer of plaster (L.3067). This reconstruction was accompanied by a poorly preserved and poorly aligned sandstone cobble curb (L.3031 [L.3055]), which connected with remains of the same curb identified to the west and east by Kaplan (see fig. 11). The curb seems to have been intended to protect the lowest course of bricks not only against traffic but also against water drainage through the passageway, since, unlike the RG-4b gate, this gate had no drain. The passage of the RG-3a gate was also resurfaced with pebbles (L.3032) and covered with compact sediment up to $11 \mathrm{~cm}$ thick in the center of the roadway (L.3066). ${ }^{129}$ The resulting gate structure retained the layout of the RG-3b gate.

${ }^{129}$ This is most likely the surface to be identified with the one

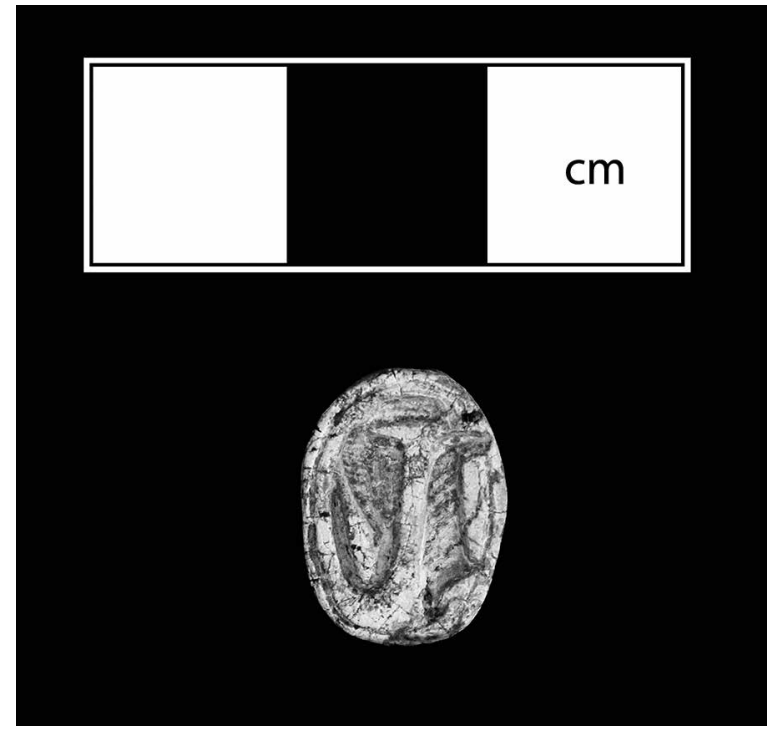

FIG. 27. Scarab (JCHP 225) found among subfloor stones (L.3011) of the phase RG-3b (level IVA) gate.

that Herzog $(2008,1792)$ described as "watertight chalky plaster," since no true plaster floor could be identified in connection with the gate of either phase RG-3b or phase RG-3a. 


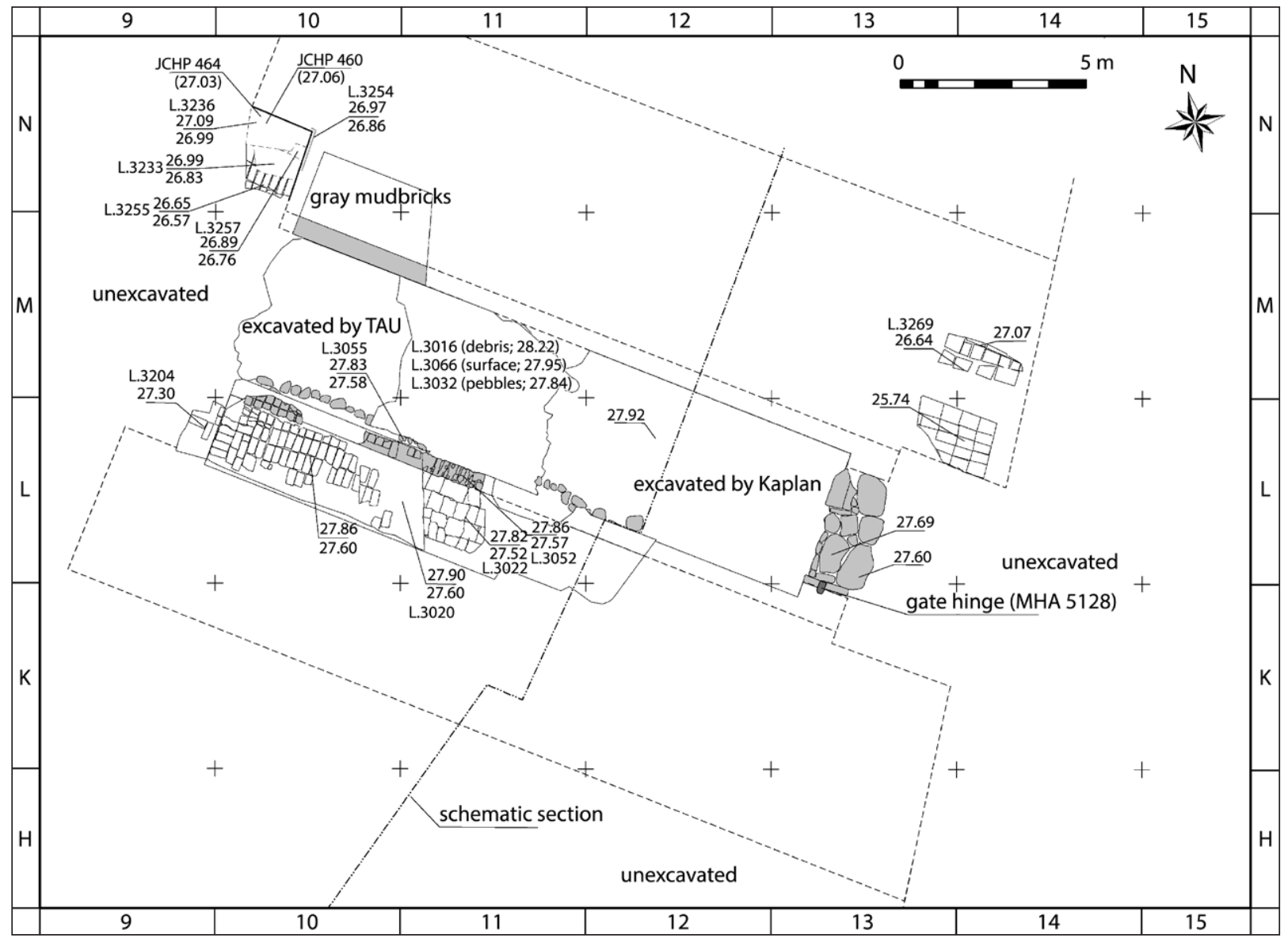

FIG. 28. Plan of Area A, phase RG-3a (level IVA) gate complex (drawing by K. Kowalski). All numbers with decimals indicate elevations (masl).

As in phase RG-3b, the repairs that ushered in the RG-3a gate included the reuse of fragments of Ramesses II's facade (from level IVB/phase RG-4a). While some fragments had been buried below the RG-3b floor (see fig. 25), during RG-3a additional fragments were reused as orthostats along the base of the passageway's walls (see fig. 11). ${ }^{130}$ The construction of the RG-3b gate had led to the raising of the gate's floor level by approximately $2 \mathrm{~m}$ relative to the interior of the fortress. That this situation prevailed during phase RG-3a is indicated by a surface encoun-

${ }^{130}$ Kaplan 1960, 122; Herzog 2008, 1792. It is unnecessary to conjecture, as Kaplan $(1972,82)$ did, that the nature of the reemployment of the stones indicated that "the inhabitants of Stratum IV $[\mathrm{B}]$ were unafraid of Egyptian authority and indifferent to what was inscribed on the stone." To the contrary, the deliberate reburial and reuse of the fragments is not atypical of Egyptian practices. Furthermore, none of the fragments recovered shows any evidence of having been intentionally effaced. tered on a landing in the niche located at the western end of the gate (L.3233; see fig. 28) in 2014, which is nearly $1 \mathrm{~m}$ below the roadway surface at the center of the gate. Since excavation of the roadway surface (L.3066) did not reveal any slope toward this landing, it is suggested that the western threshold of the gate in this period, and likely in phase RG-3b, required steps down into the fortress from the passageway.

The destruction of the RG-3a gate marks the terminus of the Egyptian fortress. This destruction was clearly identified by both Kaplan (level IVA) in 1956 and the JCHP, but apparently not during Tel Aviv University's excavations. ${ }^{131}$ Mudbrick detritus and poorly preserved traces of what were identified as fragments of timbers or planks (L.3012 [L.3064]; see fig. 5) were recovered from within the destruction debris (L.3016) during the 2011 excavations; these finds are

${ }^{131}$ Herzog 2008, 1792. 
indicative of the collapse of the gate's roof or upper story. The occupational debris associated with the RG-3a gate (L.3016; see fig. 5) yielded several wheat (Triticum sp.) seeds, of which one was radiocarbon dated (UCIAMS-159334; see fig. 21). Both the passageway surface matrix (L.3029 [L.3032]) and the fill below it (L.3038; see fig. 5) yielded another four wheat seeds, two of which (one from each context) were sampled (UCIAMS-159336 and UCIAMS-159337, respectively). During the 2014 excavations, an additional patch of RG-3a destruction debris was identified on the landing in the niche at the western end of the northern tower (see L.3236 on fig. 28). This debris yielded the lower half of a Canaanite storage jar (JCHP 460) that held numerous wheat seeds, two of which were radiocarbon dated (UCIAMS-159338 and UCIAMS-159339). An Egyptian one-handled cup with rounded base (JCHP 464; fig. 30) was also encountered next to the jar. ${ }^{132}$ It appears to be an Egyptian import on the basis of macroscopic examination of the fabric and the characteristic cream slip and burnishing. Among Egyptian examples, variants with a rounded base usually are dated to the late 19th and early 20th Dynasties, and Martin suggests that they did not appear before the 12th century in the Levant. ${ }^{133}$

Later Occupation (Phases RG-2a, RG-2b, and RG-1, Sixth Century B.C.E. and Later)

During excavations from 2011 to 2014, only a few elements of post-Bronze Age occupation were encountered (see table 4), most having been already removed by Kaplan during the 1950s. Although he also identified traces of the Iron Age (level III) and Hellenistic (level II) remains, ${ }^{134}$ none appeared within the current excavation area. Traces of Persian-period pits dug into the RG-3a remains were identified as phase RG-2b. However, foremost among the post-New Kingdom remains encountered during our excavations was the foundation of a Persian-period wall (W.3) identified as early as 1955 by Kaplan and referred to as the Sidonian Wall. ${ }^{135}$ This wall, which was assigned

\footnotetext{
${ }^{132}$ During excavations it was determined that the southern part of this deposit was excavated in 1999 by Tel Aviv University.

${ }^{133}$ Martin 2011, 80-4 (and bibliography therein).

${ }^{134}$ Kaplan and Ritter-Kaplan 1993, 656.

${ }^{135}$ This ashlar foundation wall, assigned to level II by Kaplan and Ritter-Kaplan $(1993,656)$, was consistently identified as Wall 3 in Kaplan's documentation and traced to the north and south on Kaplan's plans.
}

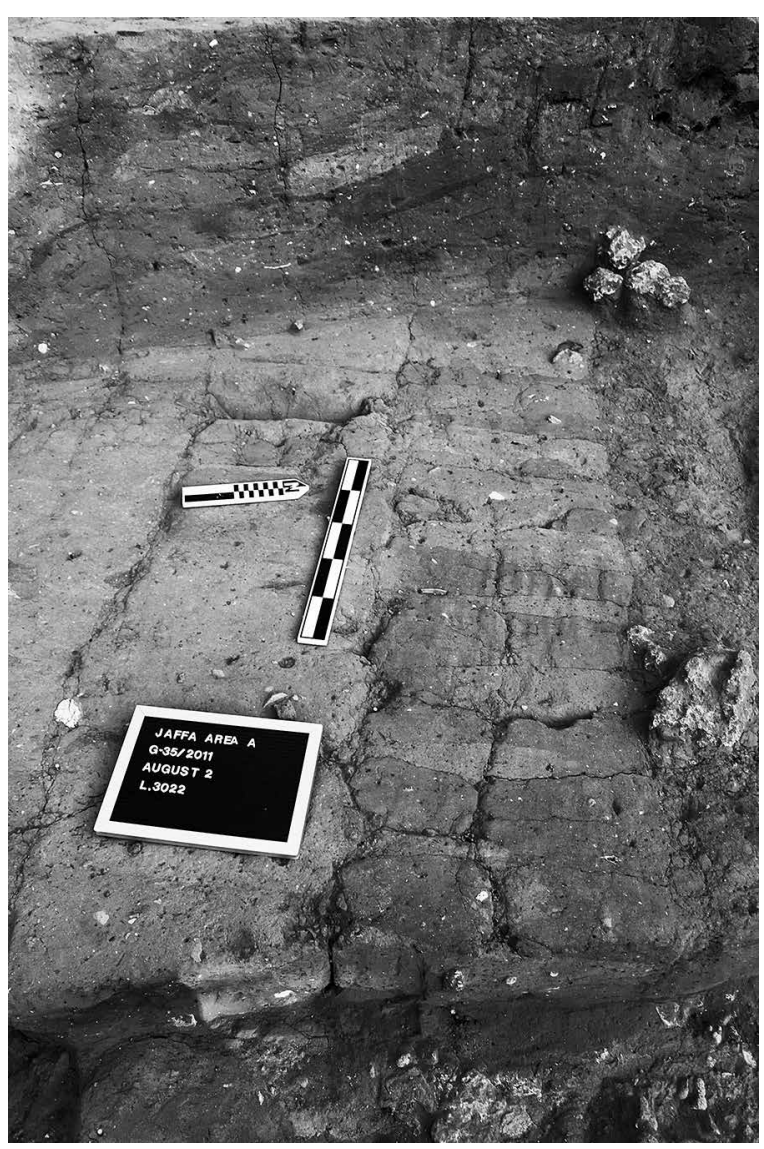

FIG. 29. Phase RG-3a (level IVA) addition (L.3022) to the interior of the passageway, view to the northwest (JCHP photograph 2011-P0444).

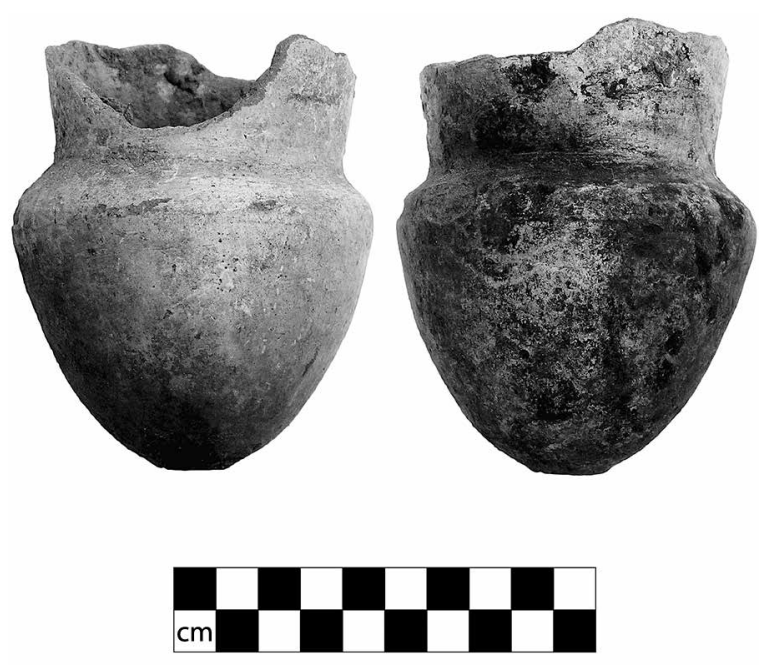

FIG. 30. Egyptian one-handled cup (JCHP 464, missing handle) from the phase RG-3a (level IVA) destruction. 
by us to phase RG-2a, ran parallel to the roughly north-south line of our grid system, preserving the Late Bronze Age stratigraphy directly below it. That the greatest height of preserved courses of the wall, four in total, lay directly above the RG-3a gate's debris likely indicates that during the Persian period a depression above the gate's original location probably existed, requiring a deeper foundation for the Persian-period wall's construction. At least one other feature suggests that architectural subphases within the Persian-period occupation can be detected.

Although Kaplan identified and recorded Ottoman remains, he did not include them in the official phasing of Jaffa's, specifically Tel Yafo's, stratigraphy. However, the locations of these features, which consisted principally of the footings of Ottoman buildings that covered the mound until 1936, explain much of the damage that was done to underlying features, which were otherwise well encased by the Ottoman remains. ${ }^{136}$ The most recent phase identified during the renewed excavations in 2011 is ascribed to modern activities carried out during Kaplan's excavations (RG1), which included undocumented restoration work to the Sidonian Wall of the Persian period, as discussed above. Careful dismantling and recording of the wall revealed that it was not originally as well preserved as it appeared in later photographs. Archival photographs established that major damage done to the feature in 1955, when it was first encountered, was repaired no later than 1956 under Kaplan's supervision. ${ }^{137}$

\section{Radiocarbon Determinations}

In addition to identifying at least two additional constructional phases of the Egyptian gate (i.e., RG-4b and RG-3b) and complete plans of each of these gates, the

\footnotetext{
${ }^{136}$ The persistence of Ottoman-period buildings until 1936 provides the most satisfactory explanation for the degree of preservation encountered for both the timbers and seed samples excavated from phase RG-4a.

${ }^{137}$ The damage appears to have been done with a backhoe that was used to clear Mandate-period debris when the area was prepared for excavation. This conclusion is based on the shape of the damage and the upturned and uplifted stones surrounding the damaged portion. The stones were repositioned, and a concrete base was added below the lowest course along the eastern face of the wall to prevent its collapse into the excavated area of the eastern half of the passageway. The conservation of this late feature is in large part responsible for the unintended protection of the isthmus of stratigraphy that connected both sides of the Egyptian gate, which remained to be excavated from 2011 to 2013 .
}

JCHP's excavations succeeded in obtaining short-lived botanical samples from the RG-4a and RG-3a gates for radiocarbon sampling. Samples from phase RG-4a, which consist of both grain and olive pits, originate from the floor of the gate's passageway and were buried beneath the destruction's collapse and thus should provide an approximate date for this event. Grain samples from phase RG-3a originate from floor composition, occupational debris, and seeds from a storage jar on the floor during the gate's final destruction.

In total, 21 samples were analyzed by two different laboratories, the W.M. Keck Carbon Cycle Accelerator Mass Spectrometry Laboratory of the University of California, Irvine (UCIAMS-dates), and the Oxford Research Accelerator Unit of the University of Oxford (OxA-dates; see fig. 21). Calibration and modeling was done using OxCal 4.2 software against the IntCal13 radiocarbon calibration curve interpolated to yearly intervals (resolution=1). ${ }^{138}$ Individual calibrations are highly consistent and mainly fall within the 12th century B.C.E., with some samples from phase RG-4a reaching into the 13 th century B.C.E. and samples from phase RG-3a stretching into the 11th century B.C.E. (see figs. 21, 31).

In order to increase the precision of the calibrated results, a Bayesian probability approach was applied. ${ }^{139}$ While all radiocarbon determinations are usually assumed to be representative for their respective contexts and stratigraphic phases, in practice residual materials that constitute outliers are often present in the archaeological record, especially in cases where one has to rely on samples that do not come from closed contexts (e.g., from a sealed storage jar where, at worst, only minimal residuality might occur). To avoid subjective, manual exclusion of samples that appear too old and thus do not "fit" the model based on stratigraphic evidence, we employed OxCal's outlier

\footnotetext{
${ }^{138}$ Bronk Ramsey 2009a; Reimer et al. 2013.

${ }^{139}$ Bayesian analysis allows additional information to be taken into account, such as the sequence of the samples based on archaeological stratigraphy. This additional information, called "prior information," is derived from sources other than, and prior to, radiocarbon analysis in the laboratory (Buck et al. 1991; Weninger et al. 2006; Bronk Ramsey 2009a). Based on the prior information and the radiocarbon measurements, a "posterior probability" for each individual sample (and each additional event in the model, such as transitions between phases) is calculated (i.e., the probability of a sample's age based on its individual calibration combined with all additional information included in the model).
} 


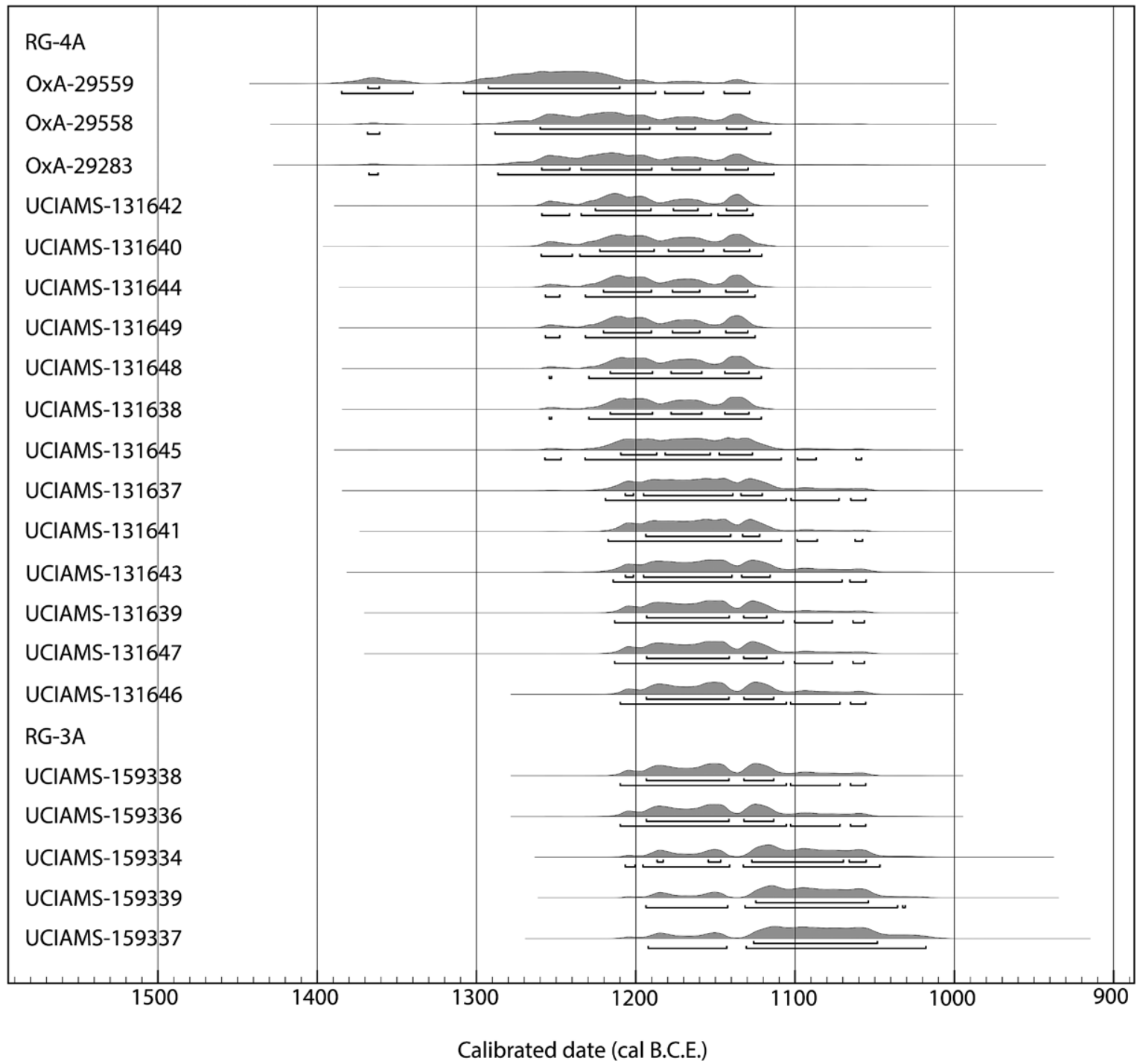

FIG. 31. Individual calibrations of radiocarbon determinations for samples from phases RG-4a (level IVB destruction) and RG-3a (level IVA destruction). Model created using OxCal 4.2.4 (Bronk Ramsey 2013) and the IntCal13 atmospheric curve, with curve resolution set at 1 (Reimer et al. 2013).

analysis, which identifies individual samples that do not fit the prior information (e.g., the sequence) and the overall model..$^{140}$ In this model, short-lived samples are expected to be representative for their respective contexts and are given only a 5\% prior chance of being an outlier. However, the posterior probability of the

\footnotetext{
${ }^{140}$ Bronk Ramsey 2009b. Based on their agreement with the model, their impact on the model's result is weighed accordingly, which means that outlying dates have very little impact on the final results (i.e., the posterior probabilities). The outlier index shows the expected (prior) chance of a sample being an outlier and the real (posterior) value based on the model.
}

result actually being an outlier is calculated by the program and differs from the prior chance. For example, UCIAMS-131642 was given a 5\% chance of being an outlier at the start, but, after the model had run, it was allocated only a 3\% chance. The radiocarbon data available for phases RG-4a and RG-3a are, however, highly consistent, and no datum qualifies as an outlier.

Based on the information concerning the recovery of the samples, this model assumes that all the shortlived samples were representative of the archaeological phases from which they were recovered and that both archaeological phases represented in the model were in the correct chronological order (i.e., phase RG-4a is 
older than RG-3a). Within each archaeological phase, however, the chronological order of the individual samples was assumed to be unknown. Samples originating from each of these stratigraphic phases were grouped together using OxCal's "phase" function (i.e., for an unordered group of events with a uniform distribution), separated by "boundaries" (i.e., the transitions between these phases). Two "boundaries" were inserted between the dates of phases RG-4a and RG-3a to account for phase RG-3b, which is not represented by radiocarbon evidence but occurred between them.

Results for this model are shown in figures 21, 31, and 32. According to the model, the terminal dates for phases RG-4a, RG-3b, and RG-3a are located within the 12th century B.C.E., most likely during the second half of the century. While there is a slight possibility that phase RG-4a was already destroyed sometime between 1200 and 1150 B.C.E., the highest probability falls to 1142-1125 B.C.E. (fig. 33). The end of phase RG-3b also has a slight possibility of falling to the first half of the 12th century B.C.E., but again, the highest probability falls to the second half, between 1134 and 1115 B.C.E. (fig. 34). The end of phase RG-3a is not as clearly defined as the RG-4a/3b and RG-3b/3a transitions, as there are no dates from contexts immediately following RG-3a to bracket its end date; the RG-2 remains are from the Persian period. Nevertheless, it is most likely that RG-3a also ended within the 12th century, probably sometime between 1127 and 1098 B.C.E. (fig. 35).

\section{JAFFA AND EVIDENCE OF RESISTANCE TO EGYPTIAN RULE IN CANAAN}

Having clarified the stratigraphic sequence within the Ramesses Gate and provided a robust basis for dating the final phases of the gate complex to the 12th century B.C.E., the results of the renewed excavations provide a unique opportunity to reevaluate resistance to and the decline of New Kingdom rule in Canaan. First, Jaffa is a distinctive type of site from which to evaluate such resistance-namely, a key Egyptian fortress and harbor town as opposed to a roadside fort, a rural agricultural estate, or an administrative enclave with Egyptian presence. No other Egyptian fortress in Canaan has been excavated, and other fortified enclaves, such as Tel Mor, are much smaller and better characterized as roadside forts or watchtowers. Beth Shean, as a site of comparable military importance if not of greater administrative stature, is the only other site with a significant Egyptian presence, but it does not feature remains of a clear fortress. More importantly, however, Beth Shean lacks both a series of clear destructions and a sequence of radiocarbon dates to nuance our understanding of the decline of Egyptian rule. ${ }^{141}$ Nevertheless, a single stele of Seti I recovered from the site reveals an episode of rebellion at Beth Shean requiring military intervention. ${ }^{142}$ This stele provides a glimpse into the material effects of resistance against one of Egypt's other strongholds in Canaan.

Before this article proceeds, some points need to be clarified concerning the interpretation of Jaffa's archaeological contexts as a fortress. First, in the absence of evidence from more extensive excavations in Jaffa to demonstrate otherwise, the excavations within the Ramesses Gate are considered representative of the situation within the fortress as a whole. While this assumption is admittedly arbitrary, it imposes a consistency on the interpretation of the observations that we can make and seeks to avoid excessive speculation concerning circumstances for which there are neither archaeological nor textual data. Second, such a perspective assumes that the circumstances experienced at fortresses serve as reasonable proxies for violence and military activity in a manner not unlike the way that the development of administrative complexes bears witness to the growth of governance and administration. A fortified gate complex within a 2 ha fortress such as Jaffa therefore becomes a proxy for the circumstances experienced at the fortress as a whole. This is also particularly true since gates were routinely attacked as weak points in, but also as symbolic of, a site's defenses. Thus, the remains of the gate complexes, which may have seen periodic destruction beginning as early as phase RG-4b, together with the remains of what may constitute the earliest destruction of the garrison during level VI late, provide a crucial basis for seeking to determine the circumstances behind these destructions. Finally, it is important to underscore that the records available for New Kingdom Canaan, despite being incomplete, repeatedly emphasize periodic rebellions, often shortly after regnal transitions. While rebellions are portrayed as threats to divine order, ${ }^{143}$ they are not accompanied, unfortunately, by lists of sites and territories that are said to have been lost to Egypt. Therefore, the tendency is to assume that campaigns targeted rebel

\footnotetext{
${ }^{141}$ Mazar 2011.

${ }^{142}$ Kitchen 2000b.

${ }^{143}$ Spalinger 2005, 77-8.
} 


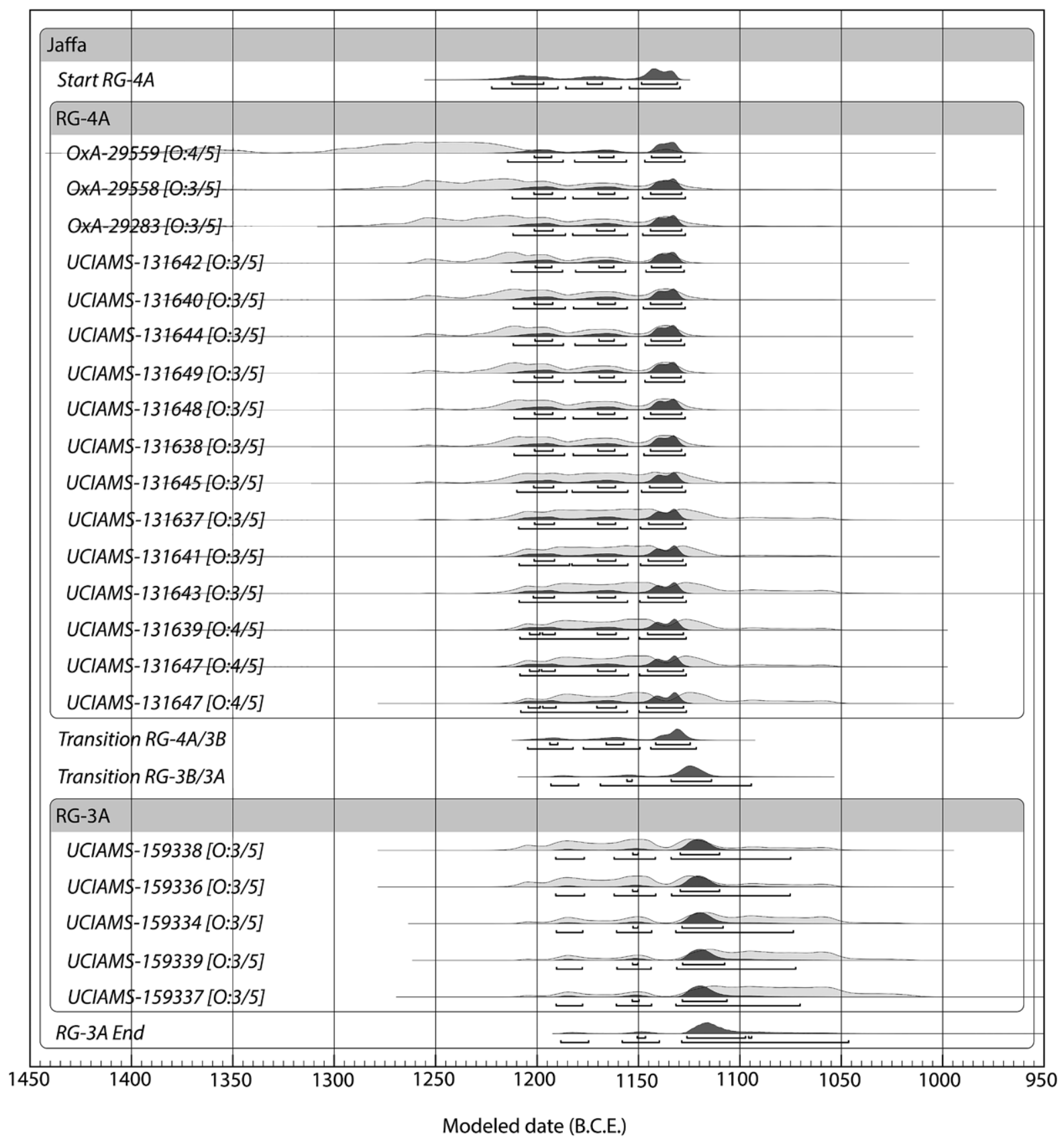

FIG. 32. Modeled probability ranges for each individual sample and their "boundaries." Light shaded areas represent individual calibrated radiocarbon determinations (lacking prior information); dark shaded areas represent modeled calibrated radiocarbon determinations (posterior probabilities) based on the prior information entered into the model. Model created using OxCal 4.2.4 (Bronk Ramsey 2013) and the IntCal13 atmospheric curve, with curve resolution set at 1 (Reimer et al. 2013).

groups, their communities, and their allies. While such assumptions are not likely to be far off, in the absence of textual sources we can rely only on archaeological evidence to test them. For Jaffa and the coastal plain, extant historical sources suggest the recurrence of localized rebellions, whether or not they were encouraged by outside powers such as the Hurrians or Hittites.
In addition to the importance of Jaffa's identity as a fortress, the sequence of radiocarbon-dated destructions of the 12th-century B.C.E. gate complex constitutes the clearest data set available thus far by which to chart the end of Egyptian rule in Canaan. In fact, few radiocarbon samples to date have been obtained from suitable Late Bronze Age contexts in the southern 


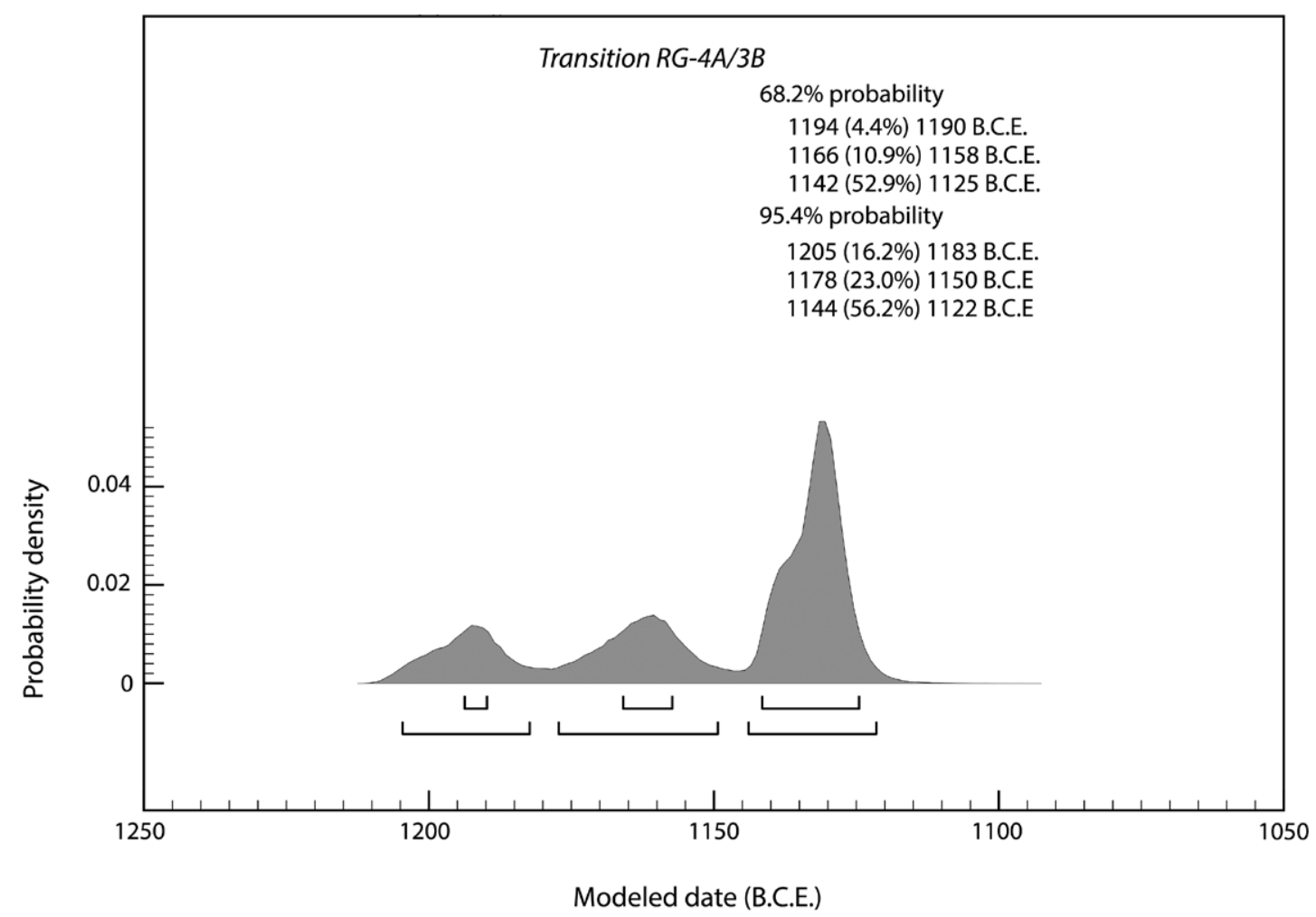

FIG. 33. Modeled date range for the transition from phases RG-4a to RG-3b. Model created using OxCal 4.2.4 (Bronk Ramsey 2013) and the IntCal13 atmospheric curve, with curve resolution set at 1 (Reimer et al. 2013).

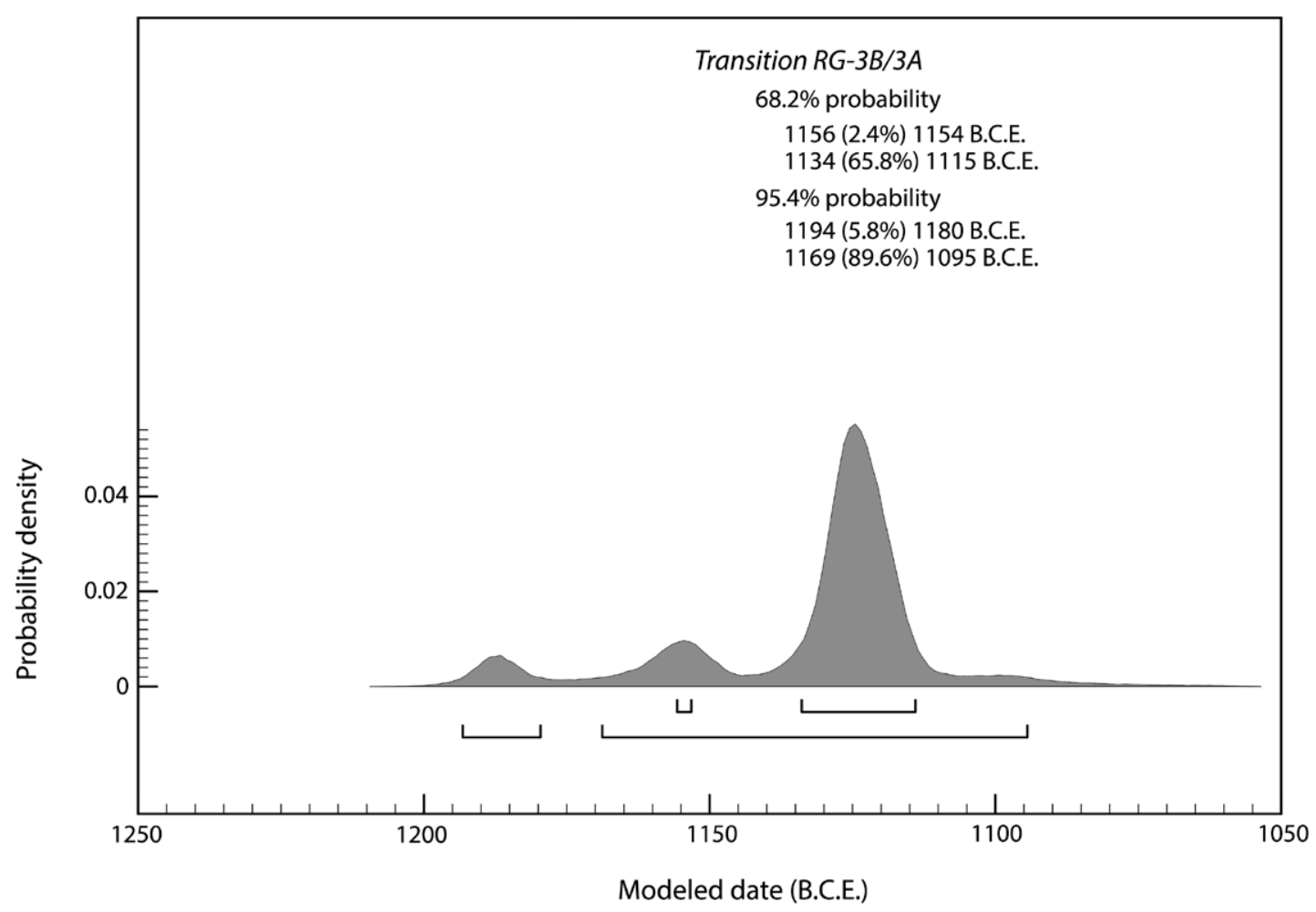

FIG. 34. Modeled date range for the transition from phases RG-3b to RG-3a. Model created using OxCal 4.2.4 (Bronk Ramsey 2013) and the IntCal13 atmospheric curve, with curve resolution set at 1 (Reimer et al. 2013). 


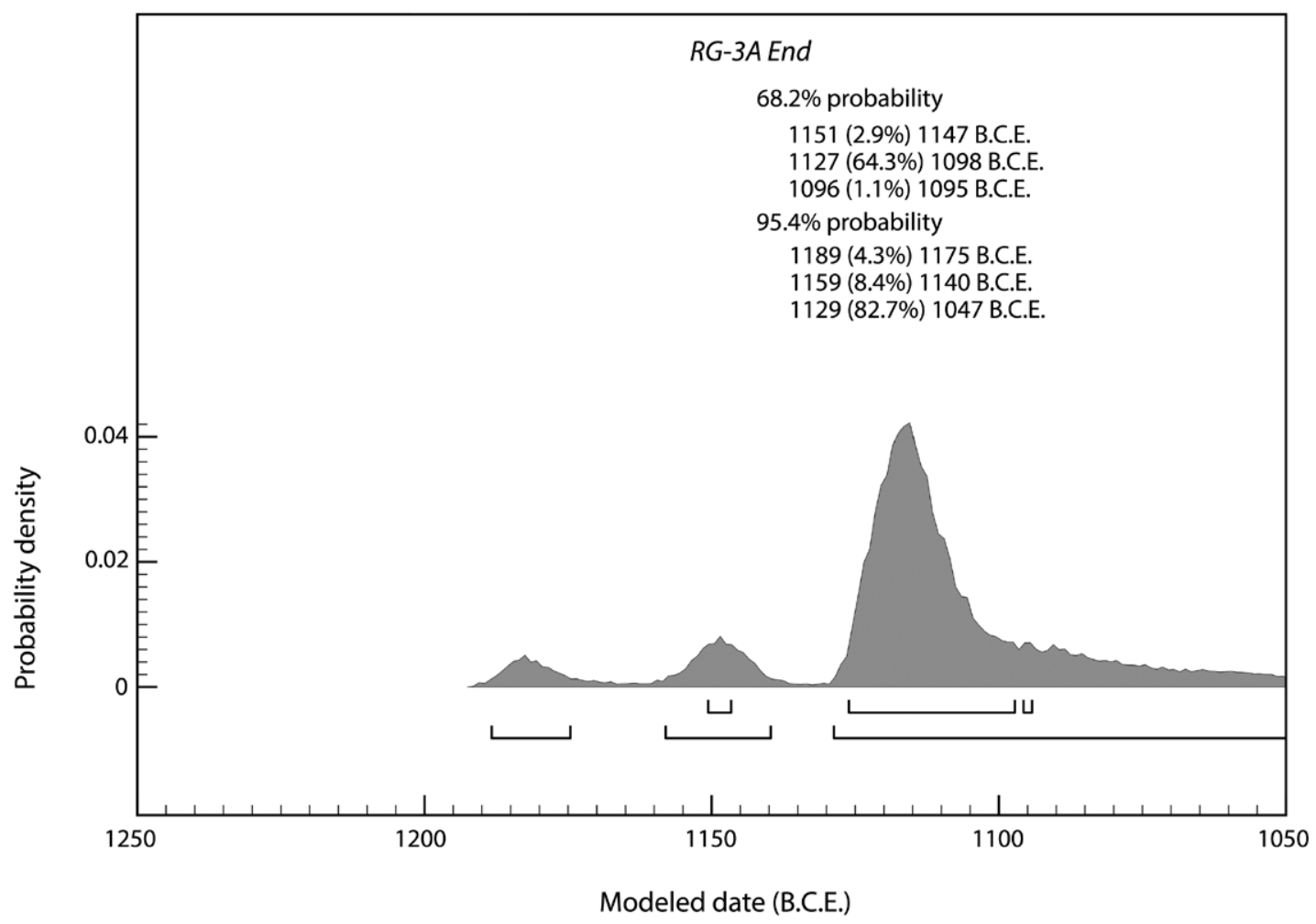

FIG. 35. Modeled date range for the end of phase RG-3a. Model created using OxCal 4.2.4 (Bronk Ramsey 2013) and the IntCal13 atmospheric curve, with curve resolution set at 1 (Reimer et al. 2013).

Levant. Those that are published fall primarily into one of two categories: (1) isolated short-lived samples (including those from tomb contexts) that do not provide a sufficiently vertical stratigraphic distribution of samples to be adequately modeled, and (2) long-lived samples of charcoal (i.e., wood) that cannot provide a date for the contexts from which they derive. ${ }^{144} \mathrm{In}$ several cases, the lack of sequences for samples has

${ }^{144}$ Late Bronze Age radiocarbon samples from Canaan include those from Aphek (Boaretto et al. 2009), Timnah (Bruins et al. 2006), Lachish (Carmi and Ussishkin 2004), Qubur el-Walaydah (Asscher et al. 2015), Beth Shean (Mazar 2007), Megiddo (Carmi and Segal 2000; Boaretto 2006), and a tomb at Sahem, Jordan (Fischer 1997). The publications of other samples are in progress for Hazor and Timnah, as well as Beth Shemesh (E. Boaretto, pers. comm. 2015). Nevertheless, most of these date determinations result from a handful of samples, often with several strata between them, and thus from phases that cannot serve to bracket the determinations for individual samples. While recent efforts have been made to model Megiddo's stratigraphy more thoroughly, the extant model for Late Bronze Age transitions is extremely coarse, with no less than 45 years allotted to each of the major transitions of relevance for the 12th to early 11 th centuries B.C.E. (Toffolo et al. 2014). resulted in a selective approach to the use of shortlived samples to date contexts, with the effect that the results are explained with respect to the dates already cited for these phases. ${ }^{145}$ Regardless of the specifics of their shortcomings, none of the available dates makes it possible to isolate a sequence of dates capable of providing a clear chronology for the end of Egyptian rule in Canaan. Furthermore, many of the sites from which samples have been recovered either were rural or were not clearly central to Egyptian rule, and for these reasons the circumstances of their destructions are ambiguous with respect to their role in conflicts relating to the close of the Egyptian empire. The following discussion therefore seeks to reconstruct a diachronic picture of resistance to, and the demise of, Egyptian

\footnotetext{
${ }^{145}$ This appears to be the case for Lachish, where many of the samples feature wider margins of error (typical of the time when they were tested), while other samples include wood, and most of the samples come from contexts widely distributed across the site and are thus related to one another by archaeological phasing rather than through clear stratigraphic sequences (Carmi and Ussishkin 2004). Such contexts are nearly impossible to model well.
} 
rule in Jaffa based on the archaeological data summarized above in concert with Egyptian textual sources both historical and literary. Particular attention is paid to Jaffa's archaeological record during the second half of the 12 th century B.C.E.

\section{Mid 18th Dynasty (ca. 1460-1400 B.C.E.): Level VI} Late

In light of Jaffa's mention in the list of Thutmose III's conquered sites and the lack of evidence for an LB IA destruction of Jaffa, it seems reasonable to conclude that the site came under Egyptian rule in the wake of the Battle of Megiddo (ca. 1460 B.C.E.) rather than because of an assault on Jaffa. Analysis of the unpublished LB IB assemblage excavated by Kaplan from level VI late (see fig. 7 ) reveals it to be a mid 18th-Dynasty assemblage and thus in line with a date at the end of the 15 th century B.C.E. The assemblage therefore constitutes the earliest evidence for an Egyptian garrison in Jaffa. Despite its limited extent, these ceramics provide the most robust LB IB Egyptian assemblage recovered in Canaan to date. Its closest parallel is a contemporaneous assemblage from Beth Shean stratum R-1b. ${ }^{146}$ The dominance of Egyptian forms in the ceramic assemblage recovered from the destruction suggests an initial stage of the Egyptian fortress when the garrison was largely independent of local — namely, Canaanite-foodways. Ceramics were produced locally in Egyptian forms and styles, and a few imported forms, such as carinated jars and storage jars, attest to particular foodstuffs being shipped to Jaffa.

Because among excavators at Jaffa Kaplan alone reached level VI late, we are left with only a single context from which to evaluate the circumstances and significance of the destruction of the earliest New Kingdom presence in Jaffa. The parsimonious explanation for this destruction, albeit tentative, is that this nearly $0.5 \mathrm{~m}$ thick ashy debris was the result of an attack on the first Egyptian garrison, a settlement that does not appear to have been as well fortified as it was after the construction of the RG-4b gate (see fig. 6). In fact, efforts to fortify the site in the wake of this event led to the removal of all traces of buildings to the north of the kitchen in order to accommodate the construction of the RG-4b gate (see fig. 16), a considerable shift in the site's character. What little remains of the level VI late settlement may reflect, therefore, the adoption of

\footnotetext{
${ }^{146}$ Mullins 2006; 2007, 440-50.
}

extant Canaanite architecture at the site for the facilities of the earliest Egyptian garrison during the LB IB.

The few historical sources that exist for the late 15th century B.C.E. suggest that the source for any potential resistance to Egyptian rule in the coastal plain was probably local. Aphek, approximately $20 \mathrm{~km}$ east of Jaffa, rebelled during the reign of Amenhotep II, requiring a military response in his ninth regnal year, ca. 1415 B.C.E. ${ }^{147}$ Thus, if the destruction identified for level VI late reflects an intentional destruction of the fortress, Aphek may have been at the center of this resistance.

In addition to the archaeological and historical sources, the Egyptian Tale of the Capture of Jaffa, as preserved in P. Harris 500, may provide not only a literary perspective but potentially also a historical memory of Canaanite resistance to Egyptian rule at about this time. Although it is usually regarded as having been written more than a century later, during the Ramesside period, it may preserve a social memory of events like those revealed in level VI late. While some scholars have assumed that this text seeks to relate or at least to construct an account of the taking of Jaffa during the reign of Thutmose III, others have suggested that the tale instead recounts the act of Egyptian forces retaking Jaffa. ${ }^{148}$ The background of the narrative, however, is missing, and the story begins only with the Egyptians led by their commander, Djehuty, preparing to take or retake Jaffa. In light of the dating of the level VI late assemblage to LB IB, if the Tale of the Capture of Jaffa reflects a historical event, we suggest that it might be better understood as relating the recapture of Jaffa, thus underscoring Jaffa's strategic importance to Egyptian military efforts and Egypt's commitment to retaining control despite setbacks. While the story itself offers little to suggest its historicity other than the commander's name and reference to a pharaoh by the name of Menkheperre (i.e., a name of Thutmose III), ${ }^{149}$ we have argued for an original setting of this story in the second half of the 15 th century. ${ }^{150}$ Following this interpretation, the destruction of level VI late Jaffa might be reckoned the result of an opening attack on the Egyptian fortress by Canaanites (a detail not preserved in the extant portion of the manuscript) that required

\footnotetext{
${ }^{147}$ Hoffmeier 2000, 19.

${ }^{148}$ Allen 2001, 347.

${ }^{149}$ For General Djehuty's identification as "Overseer of northern foreign lands" and as a historical figure, see Lilyquist 1988; Reeves 1993, 260.

${ }^{150}$ Burke and Lords 2010.
} 
Egyptian soldiers to retake the fortress. Whatever the case may be, the tale is most significant for showing that within Egyptian social memory Jaffa was remembered as a contested place from as early as the mid 18th Dynasty, which is the story's setting despite its later date of composition. Although we cannot be certain that the Egyptian retaking of Jaffa occurred in the manner recorded in this story or during a particular pharaoh's reign, the level VI late destruction may reflect the tangible threat posed by local resistance, challenging even the strongest points of Egyptian control not long after Thutmose III's suppression of the Canaanite coalition at the Battle of Megiddo (ca. 1460 B.C.E.).

\section{Late 18th Dynasty (ca. 1400-1300 B.C.E.): Phase RG-4b}

The remains of the RG-4b gate (see fig. 16) constitute the earliest evidence for Egyptian military architecture in Jaffa, laying the foundations, literally and figuratively, for Jaffa's gate for the duration of the New Kingdom settlement. The available stratigraphic data for the transition between level VI late of Kaplan's excavations and the construction of the phase RG-4b gate point to a radical shift in fortress architecture at the start of the 14th century with the expansion of its fortifications. All parallels for the construction and dimensions of the RG-4b gate derive from New Kingdom and earlier Egyptian fortresses. ${ }^{151}$ Canaanite gates, by contrast, traditionally featured three sets of piers accompanied by two chambers on each side of the passageway, appearing in plan like two "E"s facing each other. They were also smaller overall, featuring narrower passageways. ${ }^{152}$ The choice to insert the gate in this location might be explained if this was also the location of an earlier gate. Although a Canaanite gate has not yet been identified, ${ }^{153}$ mudbrick remains assigned to phase RG-5 located beneath the surface of the RG-4a passageway may belong to the Middle Bronze Age gate (i.e., RG-5). If so, construction of the RG-4b gate likely eradicated traces of an LB I gate.

The construction of the RG-4b gate immediately after the LB IB destruction, which removed much of

\footnotetext{
${ }^{151}$ For Middle Kingdom gates, see recent discussions in Vogel 2004, 2010. For recent excavation of a New Kingdom gate, see Snape and Wilson (2007, 4, fig. 1.2; 7, fig. 1.3) on Gates A and B at Zawiyet Umm el-Rakham I.

${ }^{152}$ Gregori 1986. See also Kempinski (1992) and Burke (2008, 67-70) for discussion of Middle and Late Bronze Age gates in the Levant.

${ }^{153}$ Contra Herzog 2008, 1792.
}

the stratigraphic sequence north of the 1958 sounding (see fig. 5), hampers our understanding of Jaffa's settlement in the mid 14th century B.C.E., during the late 18th Dynasty. Despite a dearth of cultural finds to associate with the RG-4b gate's remains, stratigraphic relationships point to its construction at a relatively early phase in Egyptian imperialism, at the start of the LB IIA (ca. 1400 B.C.E.). The RG-4b gate then functioned throughout the Amarna period, when Jaffa's granaries (still unidentified) functioned, as mentioned in the Amarna Letters. ${ }^{154}$ That the gate's construction took place during a nascent phase in the building of Egyptian fortifications in Canaan is also indicated from the architectural remains of the RG-4b gate. Of particular significance is the overall plan of the gate complex, which is entirely Egyptian. However, the gate's sandy brickwork is characteristic of Egyptian construction and not well suited to the amount of rainfall typical of the southern Levant, especially within the coastal zone.

It remains unclear whether the damage to the RG-4b gate resulted from an attack on the fortress during the Amarna period, a structural failure, or a general renovation. The first interpretation is favored, perhaps based on the view of the gate in section (see fig. 5). Although it was extensively damaged, the sandy brickwork was not entirely removed as might have been the case had the state of the original brickwork required its rebuilding. Rather, that these bricks remained, even including thin traces within the northern tower, suggests that efforts were made to restore and reuse not only the gate's foundation but also what remained of the superstructure during the construction of the RG-4a gate. If an attack on the fortress was responsible for the damage incurred by the RG-4b gate, which is tentatively dated to the 14th century B.C.E., then the Amarna Letters provide a reasonable starting point for seeking to identify sources of resistance to the Egyptian fortress. Since Aphek is not mentioned during this period among the Amarna Letters and since Gezer, Jaffa's nearest neighboring Canaanite polity, was engaged in rebellion under the leadership of Milkilu, it is possible that Gezer offered such resistance during the 14 th century B.C.E. ${ }^{155}$

\footnotetext{
${ }^{154}$ See supra n. 29.

${ }^{155}$ See EA 253, 254, 287, 290, 292-294, 298-300, 369, and 378 in Moran 1992. The volatility of Canaan during this period is evident in the letters concerning Gezer and its rulers, which reveal that it had three different rulers: Milkilu, Adda-danu, and Yapahu. Under these rulers Gezer was both loyal subject and a source of resistance to Egypt.
} 
In one letter from Abdi-Hepa of Jerusalem, Milkilu of Gezer is lumped together with the rebellious kings of Ashkelon and Lachish, and Egyptian archers are requested in order to oppose them. ${ }^{156}$ In another letter, Abdi-Hepa complains that Milkilu and Shuardata have brought troops from Gezer, Gimtu, and Qiltu against Jerusalem's territory, seizing Rubutu and causing other cities to defect from the Egyptian vassal's territory. ${ }^{157}$ Gezer's status among these narratives makes it a viable candidate for coordinating resistance to Egyptian rule in Jaffa, which might explain the damage done to the RG- $4 b$ gateway.

19th and Early 20th Dynasty (ca. 1300-1135

B.C.E.): Phase RG-4a

Based on its definitive association with the inscribed monumental facade of Ramesses II (see fig. 8), the construction of the RG-4a gate took place no later than the end of the reign of Ramesses II (ca. 1266-1200 B.C.E.), as first suggested by Kaplan and confirmed by the JCHP. The gate's construction may date prior to his reign, however, whether in the late 14th or the early 13th century B.C.E., since it is possible that Ramesses II simply added this inscribed facade to an extant gate. Since there is no way to be certain at this point, we employ a provisional date of ca. 1300 B.C.E. for the construction of the RG-4a gate. ${ }^{158}$ Nevertheless, the gate was restored to the original, RG-4b layout (see fig. 18). The few complete and restorable ceramic forms from this phase provide a very small assemblage from which to address Jaffa's Egyptian occupation during this period (see fig. 22), despite the extent of the debris associated with the destruction of the RG-4a gate. The Egyptian simple bowls reveal no chronologically distinct features, while the "Canaanite" jar (JCHP 251) and Cypriot pithos (MHA 2155) can have long life spans.

The RG-4a radiocarbon samples provide a date of ca. 1135 B.C.E. for the gate's destruction (see fig. 21 ), revealing Kaplan's original association of this destruction with the rebellion during Merneptah's reign (ca. 1200-1191 B.C.E.) to be too early. If a historical context is to be sought, the radiocarbon dates make it possible that this gate was destroyed in the reign of

\footnotetext{
${ }^{156}$ EA 287, lines 10-19.

${ }^{157}$ EA 290.

${ }^{158}$ Dendrochronology samples from the destruction debris may, however, clarify the constructional history of the gate complex.
}

Ramesses IV (ca. 1142-1136 B.C.E.), after the 31-year reign of Ramesses III (ca. 1173-1142 B.C.E.), the last of Egypt's militarily strong pharaohs. The radiocarbon dates reveal that the gate had a life span of at least 65 years, from ca. 1200 (i.e., the very end of the reign of Ramesses II) to 1135 B.C.E. It may have been more than a century if the gate was constructed before the reign of Ramesses II (ca. 1266-1200 B.C.E.) and only provided with an ornamental facade during his reign (see fig. 8). ${ }^{159}$ Before its final destruction, this phase of the gate shows no evidence of damage due to military activity against the garrison, and thereby it may provide a witness to the relative success of pharaonic policies during this time span. Based on historical sources, Ramesses II does not appear to have been troubled by rebellions in Canaan and was also able to limit Hittite interference to the northern Levant. ${ }^{160}$ While Merneptah experienced a rebellion in the southern coastal plain during his reign, ${ }^{161}$ the archaeology of Jaffa provides no evidence that the fortress suffered an attack during his reign, though Jaffa could have served as a staging point for Merneptah's military response.

Early 20th Dynasty (ca. 1135-? B.C.E.): Phase RG$3 b$

Despite the extensive destruction of the RG-4a gate, the gate was rapidly rebuilt, following its earlier plan, on top of the debris. This occurred at the start of phase RG-3b (see fig. 25), sometime during the early 20th Dynasty. The stratigraphic depositions of leveling fills above the RG-4a destruction debris, which were intended to prepare the area for the floor of the RG-3b gate, provide no indications of a seasonal gap during this process, suggesting that little or no time elapsed between the RG-4a gate's destruction and the RG-3b gate's rebuilding. The gate's construction can also be reasonably well correlated with Kaplan's so-called citadel in the Lion Temple area, ${ }^{162}$ primarily on the basis of the brickwork, which was composed of identically sized gray bricks. ${ }^{163}$ Although the Qudshu-plaque figurine and the Amenhotep III scarab originated from

\footnotetext{
159 The dating of timbers used in the construction of the RG-4a gate may provide a sense of the dates of the phases of its construction.

${ }^{160}$ For an overview of the reign of Ramesses II, see Kitchen 1982.

${ }^{161}$ Lichtheim 1976, 77.

${ }^{162}$ Kaplan and Ritter-Kaplan 1993, 658.

${ }^{163}$ Herzog 2008, 1792.
} 
the gray bricks of the RG-3b gate, the gate passageway yielded no material culture of consequence associated with its use, and few ceramic sherds were recovered from the limited exposure of the passageway excavated in $2011 .{ }^{164}$

Mid-20th Dynasty (ca. ?-1125 B.C.E.): Phase RG-3a

It is not entirely clear to what extent the RG-3b gate was damaged as the result of military action against the fortress. It is possible that basic stabilization efforts were made for the gate's interior walls (see fig. 5) at the start of phase RG-3a. These were replaced along the south side of the passageway (see figs. 26, 28). It could not be determined, however, whether similar repairs were made to the northern tower along the passageway. These repairs, together with several relatively clean occupational debris layers, form the basis of the distinction of the RG-3a gate from that of phase RG-3b.

Radiocarbon determinations for remains from the destruction of phase RG-3a indicate that this was a very short-lived phase, perhaps only a decade during the mid 20th Dynasty (see fig. 21). These dates complement the evidence of the remains of the level IVA gate's threshold excavated by Kaplan. There, a bronze gate hinge standing at a right angle to the passage suggests that the doors of the Egyptian gate were closed at the time of its destruction (see fig. 13). Without this data, the destruction of the RG-3a gate would be more ambiguous, especially when compared with that of the RG-4a gate. The Tel Aviv University expedition, for example, did not identify evidence of a destruction, and the trace remains of charcoal encountered in the 2011 excavations within the debris above the gateway floor were not, in and of themselves, compelling evidence for the identification of a destruction layer. The disturbance of the destruction debris following the site's abandonment by the Egyptians and up through the Ottoman period, however, reveals how site-formation processes have affected this context. The loss of the second gate hinge on the north side of the threshold, for example, reveals the effects of these later processes, as does the British Mandate pipe lying across the LB III threshold (see fig. 13, right). Nevertheless, our excavations identified trace remains of this destruction debris above the occupational debris of RG-3a, which corroborate Kaplan's original findings. The degraded remains of this final destruction serve, therefore, as a

\footnotetext{
${ }^{164} \operatorname{Herzog}(2008,1792)$ likewise notes the dearth of material culture associated with this phase of the gate.
}

reminder of the varied signatures left by destructions, whether those signatures reflect the severity of the event or the effects of post-depositional processes on a destruction context.

Based on the radiocarbon data, a date at or after 1125 B.C.E., around the middle of the 20th Dynasty, can be suggested for the final destruction of the RG-3a gate and Egypt's abandonment of the fortress. Such a late date for the destruction of this gate is particularly significant given that the end of the reign of Ramesses VI, cited as ca. 1130 B.C.E. on the low chronology, is traditionally invoked for the end of Egyptian rule in Canaan. ${ }^{165}$ This date is, however, rather arbitrary. It is primarily based on the recovery of a statue base inscribed with the name of Ramesses VI from Megiddo, which, although it was recovered from stratum VIIB, ${ }^{166}$ is thought to have been intentionally buried during stratum VIIA. What the discovery of this artifact in this context suggests, however, is uncertain and is entirely a matter of speculation based on perceptions of Megiddo's place within Egyptian imperial policy, the identification of the agents of Megiddo's destruction during this period, and the intentions of whoever buried the statue base. On these issues there is no consensus. ${ }^{167}$

\section{Mid 20th to 21st Dynasty (11th Century B.C.E.): Level IIIB}

Although the excavations since 2011 encountered no contexts from the 11 th century B.C.E., Jaffa's radiocarbon dates for the destruction of phase RG-3a provide an important terminus post quem of ca. 1125 B.C.E. for Philistine presence in Jaffa during Iron I. Philistine presence in Jaffa is inferred by the appearance of Philistine 3 ceramics in level IIIB. The absence of Philistine ceramics within phases RG-3b or RG-3a (Kaplan's level IVA) supports the traditional pattern of physical and temporal separation between "Philistine" sites and Egyptian centers. ${ }^{168}$ The renewed excavations were unable, however, to address Kaplan's suggested gap between levels IVA and IIIB. The context of Jaffa's Philistine 3 ceramics and the absence of other markers of Philistine settlement (e.g., hearths, domestic architecture, loomweights) indicate that Philistine presence

\footnotetext{
${ }^{165}$ Ussishkin 1995; see also Mazar 1990, 296-97.

${ }^{166}$ Breasted 1948, 135 n. 1.

${ }^{167}$ Ceramics also provide no chronological control for dating the end of Egyptian rule in Canaan, as recently noted in Martin 2011, 249.

${ }^{168}$ Stager 1995.
} 
in Jaffa may have been ephemeral and effectively constituted a squatter occupation following the departure of the Egyptian garrison. Nevertheless, the Philistine 3 ceramics from Jaffa also correlate well with the more substantial data during this period from Tel Qasile, across the Yarkon River to Jaffa's northeast. ${ }^{169}$

\section{CONCLUSIONS}

The Egyptian gate excavations begun by Kaplan during the late 1950s, continued by Tel Aviv University during the late 1990s, and resumed by the Jaffa Cultural Heritage Project from 2011 to 2014 provide a unique perspective on New Kingdom control of Canaan and local resistance to it. The results of these excavations in combination with historical records illustrate the recurrence of violent interactions throughout this period, which reached their peak during the 12th century B.C.E. While some destructions of Jaffa's fortress are conspicuous (i.e., level VI late, phases RG-4a and RG-3a) and other possible destructions can be debated (i.e., phase RG-4b), Jaffa's archaeological contexts along with textual sources spanning a little more than three centuries reveal that resistance was a recurrent threat to Egyptian control of Jaffa and its hinterland. While Jaffa's destructions may provide only occasional evidence of resistance, other incidents of resistance to the garrison or within the region may have left no physical traces. Jaffa's destructions therefore provide evidence, albeit limited, of resistance to Egyptian rule for which we are otherwise entirely reliant on the incomplete references provided by the few New Kingdom sources concerned with this region.

There is no clear evidence to indicate that any of the destructions in question represent localized, and so perhaps accidental, phenomena that were restricted to a single room or building within the fortress. Furthermore, no distinct markers of earthquake destruction could be identified, such as slipping of walls or individuals buried below collapsed debris. However, the RG-4a destruction, for example, furnished evidence of arrowheads and a spearhead, and the RG-3a destruction revealed that the doors of the gateway were closed when they burned. The destructions therefore reveal a pattern of violence at the fortress that intensified during the second half of the 12 th century B.C.E., a period traditionally regarded as marking the end of Egyptian rule in Canaan.

\footnotetext{
${ }^{169}$ Mazar 1993.
}

While the immediate agents of this resistance may remain ambiguous, textual sources reveal periodic rebellions against Egyptian rule in the coastal plain. Among these sources there is no evidence for the presence of an invading force. Neither the Hittites nor the Hurrians before them fielded an army in Canaan to account for early destructions, and Jaffa's late 12th-century B.C.E. destructions reveal no basis for associations with the Sea Peoples, who arrived early in the reign of Ramesses III. Texts and inscriptions identify sources of resistance among communities of the coastal plain. Already during the first nine years of the reign of Amenhotep II (ca. 1424-1398 B.C.E.), Aphek, located less than $20 \mathrm{~km}$ northeast of Jaffa (see fig. 1), had revolted twice. ${ }^{170}$ The Canaanite enclave at Gezer, which is located about 25 $\mathrm{km}$ to the southeast of Jaffa, played a central and strategic role in Egyptian concerns during the Amarna period (ca. 1388-1344 B.C.E.), as revealed in the Amarna Letters. ${ }^{171}$ During Merneptah's reign (ca. 1200-1191 B.C.E.), the Canaanite rebellion in the coastal plain included both Ashkelon and Gezer. ${ }^{172}$ Thus, at different points throughout the New Kingdom, resistance to Egyptian control of Jaffa shifted among Canaanite centers in the coastal plain, such as Aphek, Gezer, and possibly Ashkelon. For these reasons, local resistance by Canaanites provides the most likely source of resistance to the Egyptian garrison in Jaffa, as also described in the Tale of the Capture of Jaffa, which was written during the Ramesside period but retrojected into the mid 18th Dynasty. Yet, despite the destruction of the fortress, no evidence suggests Canaanite reoccupation of the site during the Late Bronze Age.

Datable archaeological evidence of resistance from a fortress such as Jaffa suggests that broader patterns of resistance to Egyptian domination may also be identified at other sites, permitting us to further examine how narratives of resistance can be integrated with traditional understandings of Egyptian control of Canaan during the New Kingdom. In the case of Jaffa, the terminus post quem radiocarbon dating for the final destruction of the Egyptian fortress (i.e., phase RG-3a) to ca. 1125 B.C.E. provides the most solid basis available to date for suggesting that Ramesses VI likely presided over the onset of a serious decline of New Kingdom rule in Canaan and quite possibly a withdrawal of much

\footnotetext{
${ }^{170}$ Hoffmeier 2000, 19.

${ }^{171}$ See supra n. 155.

${ }^{172}$ See Merneptah's Stele (Pritchard 1969, 376-78).
} 
of Egypt's military presence. Although such a historical correlation can be debated, its proposal underscores that these destructions were historically contingent and set within the reigns of particular pharaohs and that Jaffa, as a site of military importance to Egyptian imperial policies, can serve as a means of evaluating the success or failure of Egyptian efforts.

\section{Aaron A. Burke}

Department of Near Eastern Languages and Cultures

University of California, Los Angeles

Los Angeles, California 90095

aaburke@ucla.edu

Martin Peilstöcker

FB 01, Seminar für Altes Testament und Biblische Archäologie

Johannes-Gutenberg Universität Mainz

55099 Mainz

Germany

peilstoe@uni-mainz.de

Amy Karoll, abkaroll@gmail.com

George A. Pierce, geopierce@gmail.com

Krister Kowalski, kowalskk@uni-mainz.de

Nadia Ben-Marzouk, nadiabenmarzouk@gmail.com

Jacob C.Damm, j.c.damm@gmail.com

Andrew J. Danielson, danielson.a.j@gmail.com

Heidi D. Fessler, heidimfessler@gmail.com

Brett Kaufman, brett_kaufman@brown.edu

Krystal V.L. Pierce, krystalvlpierce@gmail.com

Felix Höflmayer, felix.hoeflmayer@oeaw.ac.at

Brian N.Damiata, damiata@ucla.edu

Michael Dee, michael.dee@rlaha.ox.ac.uk

\section{Works Cited}

Ajami, M. 2011. "Cultural Heritage Management: The Flea Market and Clock Tower Square Excavations." In The History and Archaeology of Jaffa. Vol. 1, edited by M. Peilstöcker and A.A. Burke, 33-40. Jaffa Cultural Heritage Project 1, Monumenta archaeologica 26. Los Angeles: Cotsen Institute of Archaeology.

Allen, J.P. 2001. "Taking of Joppa." In The Oxford Encyclopedia of Ancient Egypt, edited by D.B. Redford, 347-48. New York: Oxford University Press.

Amiran, R. 1970. Ancient Pottery of the Holy Land: From Its Beginnings in the Neolithic Period to the End of the Iron Age. New Brunswick: Rutgers University Press.

Asscher, Y., G. Lehmann, S.A. Rosen, S. Weiner, and E. Boaretto. 2015. "Absolute Dating of the Late Bronze to Iron Age Transition and the Appearance of Philistine Culture in Qubur El-Walaydah, Southern Levant.” Radiocarbon 57(1):77-97.

Aston, D.A., and E.B. Pusch. 1999. "The Pottery from the Royal Horse Stud and Its Stratigraphy: The Pelizaeus Mu- seum Excavation at Qantir/Per-Ramesses, Sector QIV." Ägypten und Levante 9:39-75.

Ayash, E., and A. Buchennino. 1999. "Yafo (Jaffa)." Hadashot Arkheologiyot-Excavations and Surveys in Israel 109:97*, 144-45.

Barako, T., ed. 2007. Tel Mor: The Moshe Dothan Excavations, 1959-1960. IAA Reports 32. Jerusalem: Israel Antiquities Authority.

Bar-Nathan, R. 2002. “The Jacob Kaplan and Haya RitterKaplan Legacy." Hadashot Arkheologiyot_Excavations and Surveys in Israel 114:104*-9*.

Ben-Shlomo, D. 2006. Decorated Philistine Pottery: An Archaeological and Archaeometric Study. BAR-IS 1541. Oxford: Archaeopress.

Boaretto, E. 2006. “Radiocarbon Dates.” In Megiddo. Vol. 4, The 1998-2002 Seasons, edited by I. Finkelstein, D. Ussishkin, and B. Halpern, 550-57. Monograph Series 24. Jerusalem: Emery and Claire Yass Publications in Archaeology, Institute of Archaeology, Tel Aviv University Press.

Boaretto, E., A. Gilboa, and I. Sharon. 2009. "Radiocarbon Dating." In Aphek-Antipatris. Vol. 2, The Remains on the Acropolis, The Moshe Kochavi and Pirhiya Beck Excavations, edited by Y. Gadot and E. Yadin, 575-78. Monograph Series 27. Tel Aviv: Emery and Claire Yass Publications in Archaeology, Institute of Archaeology, Tel Aviv University Press.

Bourriau, J.D., P.T. Nicholson, and P.J. Rose. 2000. “Pottery.” In Ancient Egyptian Materials and Technology, edited by P.T. Nicholson and I. Shaw, 121-47. Cambridge: Cambridge University Press.

Breasted, J.H. 1948. "Bronze Base of a Statue of Ramses VI Discovered at Megiddo." In Megiddo. Vol. 2, Seasons of 1935-39, edited by G. Loud, 135-38. OIP 62. Chicago: The University of Chicago Press.

Bronk Ramsey, C. 2009a. "Bayesian Analysis of Radiocarbon Dates." Radiocarbon 51(1):337-60.

_.2009b. "Dealing with Outliers and Offsets in Radiocarbon Dating." Radiocarbon 51(3):1023-45.

.2013. OxCal Online Radiocarbon Calibration. Version 4.2. Oxford: Radiocarbon Accelerator Unit, University of Oxford. https://c14.arch.ox.ac.uk/oxcal.html.

Bruins, H.J., H. van der Plicht, and A. Mazar. 2006. "Radiocarbon Dates from Tel Batash.” In Timnah (Tel Batash). Vol. 3, The Finds from the Second Millennium BCE, edited by N. Panitz-Cohen and A. Mazar, 319-22. Qedem 45. Jerusalem: Institute of Archaeology, Hebrew University of Jerusalem Press.

Buck, C.E., J.B. Kenworthy, C.D. Litton, and A.F.M. Smith. 1991. "Combining Archaeological and Radiocarbon Information: A Bayesian Approach to Calibration." Antiquity 65:808-21.

Burke, A.A. 2008. "Walled Up to Heaven": The Evolution of Middle Bronze Age Fortification Strategies in the Levant. Studies in the Archaeology and History of the Levant 4. Winona Lake, Ind.: Eisenbrauns.

. 2009. "The 2008 Annual Report of the Jaffa Cultural Heritage Project." Backdirt 2009:34-5.

. 2010. "Canaan Under Siege: The History and Archaeology of Egypt's War in Canaan During the Early 
Eighteenth Dynasty." In Studies on War in the Ancient Near East: Collected Essays on Military History, edited by J. Vidal, 43-66. Alter Orient und Altes Testament 372. Münster: Ugarit-Verlag.

.2011a. "Early Jaffa: From the Bronze Age to the Persian Period." In The History and Archaeology of Jaffa. Vol. 1, edited by M. Peilstöcker and A.A. Burke, 63-78. Jaffa Cultural Heritage Project 1, Monumenta archaeologica 26. Los Angeles: Cotsen Institute of Archaeology.

. 2011b. "The Kaplan Excavations Publication Initiative." In The History and Archaeology of Jaffa. Vol. 1, edited by M. Peilstöcker and A.A. Burke, 239-42. Jaffa Cultural Heritage Project 1, Monumenta archaeologica 26. Los Angeles: Cotsen Institute of Archaeology.

. 2011c. “The Jaffa Cultural Heritage Project: Progress Report for 2009-2010." Backdirt 2011:71-4.

_. 2012. "The Jaffa Cultural Heritage Project: The 2011 Season." Backdirt 2012:79-82.

Burke, A.A., and K.S. Burke. 2008. "Investigating a Forgotten Port: The Jaffa Cultural Heritage Project." Backdirt 2008:70-5.

Burke, A.A., and K.V.Lords. 2010. "Egyptians in Jaffa: A Portrait of Egyptian Presence in Jaffa During the Late Bronze Age." NEA 73(1):2-30.

Burke, A.A., and A.R. Mandell. 2011. "Egyptian 'Flowerpots' from Kaplan's Area A Excavations: Cultural and Historical Implications." In The History and Archaeology of Jaffa. Vol. 1, edited by M. Peilstöcker and A.A. Burke, 261-70. Jaffa Cultural Heritage Project 1, Monumenta archaeologica 26. Los Angeles: Cotsen Institute of Archaeology.

Burke, A.A., and M. Peilstöcker. 2009. "Notes and News: The Jaffa Visitors' Centre, 2008.” IEJ 59(2):220-27.

- 2011. "The Jaffa Cultural Heritage Project: Objectives, Organization, Strategies, and Implementation." In The History and Archaeology of Jaffa. Vol. 1, edited by M. Peilstöcker and A.A. Burke, 3-15. Jaffa Cultural Heritage Project 1, Monumenta archaeologica 26. Los Angeles: Cotsen Institute of Archaeology.

Burke, A.A., M. Peilstöcker, and G.A. Pierce. 2014. "Hellenistic Architecture in Jaffa: The 2009 Excavations of the Jaffa Cultural Heritage Project in the Visitor's Centre." PEQ 146(1):40-55.

Carmi, I., and D. Segal. 2000. “Radiocarbon Dates.” In Megiddo. Vol.3, The 1992-1996 Seasons, edited by I. Finkelstein, D. Ussishkin, and B. Halpern, 502-3. Monograph 18. Jerusalem: Emery and Claire Yass Publications in Archaeology, Institute of Archaeology, Tel Aviv University Press.

Carmi, I., and D. Ussishkin. 2004. " ${ }^{14}$ C Dates." In The Renewed Archaeological Excavations at Lachish (1973-1994). Vol. 5, edited by D. Ussishkin, 2508-13. Monograph Series 22. Tel Aviv: Emery and Claire Yass Publications in Archaeology, Institute of Archaeology, Tel Aviv University Press.

Davies, N.d.G. 1930. The Tomb of Ken-Amün at Thebes. Egyptian Expedition 5. New York: Metropolitan Museum of Art.

Dothan, T., and B. Brandl, eds. 2010a. Deir el-Balah: Excavations in 1977-1982 in the Cemetery and Settlement. Vol. 1, Stratigraphy and Architecture. Qedem 49. Jerusalem: Israel Exploration Society. eds. 2010b. Deir el-Balah: Excavations in 1977-1982 in the Cemetery and Settlement. Vol. 2, The Finds. Qedem 50. Jerusalem: Israel Exploration Society.

Dothan, T., S. Gitin, and A. Zukerman. 2006. "The Pottery: Canaanite and Philistine Traditions and Cypriote and Aegean Imports." In Tel Miqne-Ekron Excavations, 1995-1996: Field INE East Slope, Iron Age I (Early Philistine Period), edited by M.W. Meehl, T. Dothan, and S. Gitin, 71-175. Tel Miqne-Ekron Final Field Report Series 8. Jerusalem: W.F. Albright Institute of Archaeological Research and the Institute of Archaeology, Hebrew University of Jerusalem Press.

Epstein, C. 1966. Palestinian Bichrome Ware. Documenta et monumenta Orientis antiqui 12. Leiden: Brill.

Fischer, P.M. 1997. A Late Bronze to Early Iron Age Tomb at Sahem, Jordan. Abhandlungen des Deutschen PalästinaVereins 21. Wiesbaden: Harrassowitz.

—. 2014. "The Southern Levant (Transjordan) During the Late Bronze Age." In The Oxford Handbook of the Archaeology of the Levant (c. 8000-332 BCE), edited by M.L. Steiner and A.E. Killebrew, 561-76. Oxford: Oxford University Press.

Fischer, P.M., and M. Sadeq. 2008. “'Ajjul, Tell el-.” In The New Encyclopedia of Archaeological Excavations in the Holy Land, edited by E. Stern, 1565-66. Jerusalem: Israel Exploration Society.

Gadot, Y. 2010. "The Late Bronze Egyptian Estate at Aphek." TelAviv 37:48-66.

Gadot, Y., and E. Yadin, eds. 2009. Aphek-Antipatris. Vol. 2, The Remains on the Acropolis, The Moshe Kochavi and Pirhiya Beck Excavations. Monograph Series 27. Tel Aviv: Emery and Claire Yass Publications in Archaeology, Institute of Archaeology, Tel Aviv University Press.

Gavish, D. 2013. “'Operation Anker': Die Zerstörung Jaffas 1936." In Jaffa: Tor zum Heiligen Land, edited by M. Peilstöcker, J. Schefzyk, and A.A. Burke, 146-50. Mainz: Nünnerich-Asmus.

Gophna, R. 2002. "Elusive Anchorage Points Along the Israel Littoral and the Egyptian-Canaanite Maritime Route During Early Bronze Age I." In Egypt and the Levant: Interrelations from the 4th Through the Early 3rd Millennium B.C.E., edited by E.C.M. van den Brink and T.E. Levy, 418-21. New Approaches to Anthropological Archaeology. London: Leicester University Press.

Gregori, B. 1986. “'Three-Entrance’ City-Gates of the Middle Bronze Age in Syria and Palestine." Levant 18:83-102.

Hasel, M.G. 1998. Domination and Resistance: Egyptian Military Activity in the Southern Levant, ca. 1300-1185 B.C. Probleme der Ägyptologie 10. Leiden: Brill.

Herzog, Z. 1986. Das Stadttor in Israel und in der Nachbarländern. Translated by M. Fischer. Mainz: Philipp von Zabern. . 2008. "Jaffa." In The New Encyclopedia of Archaeological Excavations in the Holy Land, edited by E. Stern, 179192. Jerusalem: Israel Exploration Society.

Higginbotham, C.R. 2000. Egyptianization and Elite Emulation in Ramesside Palestine: Governance and Accommodation on the Imperial Periphery. Culture and History of the Ancient Near East 2. Boston: Brill.

Hoffmeier, J.K. 2000. "The Memphis and Karnak Stelae of Amenhotep II (2.3).” In The Context of Scripture. Vol. 2, 
Monumental Inscriptions from the Biblical World, edited by W.W. Hallo, 19-23. Leiden: Brill.

Horowitz, W., T. Oshima, and S. Sanders. 2006. Cuneiform in Canaan: Cuneiform Sources from the Land of Israel in Ancient Times. Jerusalem: Israel Exploration Society.

Kaplan, J. 1956. “Notes and News: Jaffa.” IEJ 6(4):259-60. 1959. The Archaeology and History of Tel Aviv-Jaffa.

Tel Aviv: Massada.

- 1960. "Notes and News: Jaffa." IEJ 10(2):121-22. 1961. “Notes and News: Jaffa.” IEJ 11(4):191-92. 1962. "Notes and News: Jaffa." IEJ 12(2):149-50. 1964. "Notes and News: Jaffa." IEJ 14(4):285-86. 1966. "Notes and News: Tel Aviv-Yafo." IEJ 16(4):282-83.

.1970. "Notes and News: Tel Aviv-Yafo." IEJ20(3-4): 225-26.

174

74.

1972. "The Archaeology and History of Tel-AvivJaffa.” Biblical Archaeologist 35(3):66-95.

. 1974. "Notes and News: Jaffa, 1972-1973." IEJ24(2): 135-37.

Kaplan, J., and H. Kaplan. 1975. "Notes and News: Jaffa, 1974.” IEJ 25(2-3):163.

Kaplan, J., and H. Ritter-Kaplan. 1993. "Jaffa." In The New Encyclopedia of Archaeological Excavations in the Holy Land, edited by E. Stern, 655-59. Jerusalem: Israel Exploration Society.

Keimer, K.H. 2011. "Area B: A Test Case for the Publication of the Kaplans' Excavations in Jaffa." In The History and Archaeology of Jaffa. Vol. 1, edited by M. Peilstöcker and A.A. Burke, 251-59. Jaffa Cultural Heritage Project 1, Monumenta archaeologica 26. Los Angeles: Cotsen Institute of Archaeology.

Kemp, B.J. 2000. "Soil (Including Mud-Brick Architecture)." In Ancient Egyptian Materials and Technology, edited by P.T. Nicholson and I. Shaw, 78-103. Cambridge: Cambridge University Press.

Kempinski, A. 1992. "Middle and Late Bronze Age Fortifications." In The Architecture of Ancient Israel: From the Prehistoric to the Persian Periods, edited by A. Kempinski and R. Reich, 127-42. Jerusalem: Israel Exploration Society.

Killebrew, A.E. 2004. "New Kingdom Egyptian-Style and Egyptian Pottery in Canaan: Implications for Egyptian Rule in Canaan During the 19th and Early 20th Dynasties." In Egypt, Israel, and the Ancient Mediterranean World: Studies in Honor of Donald B. Redford, edited by G.N. Knoppers and A. Hirsch, 309-43. Probleme der Ägyptologie 20. Leiden: Brill.

-2005. Biblical Peoples and Ethnicity: An Archaeological Study of Egyptians, Canaanites, Philistines, and Early Israel 1300-1100 B.C.E. Archaeology and Biblical Studies 9. Atlanta: Society of Biblical Literature.

_.2010. "The Canaanite Pottery." In Deir el-Balah: Excavations in 1977-1982 in the Cemetery and Settlement. Vol. 2, The Finds, edited by T. Dothan and B. Brandl, 75-109. Qedem 50. Jerusalem: Israel Exploration Society.

Kitchen, K.A. 1982. Pharaoh Triumphant: The Life and Times of Ramesses II. Warminster: Aris and Phillips.
1994. Ramesside Inscriptions Translated and Annotated. Vol. 2, Ramesses II, Royal Inscriptions. Oxford: Blackwell.

. 2000a. "Regnal and Genealogical Data of Ancient Egypt (Absolute Chronology I): The Historical Chronology of Ancient Egypt. A Current Assessment." In The Synchronisation of Civilisations in the Eastern Mediterranean in the Second Millennium B.C.: Proceedings of an International Symposium at Schloss Haindorf, 15th-17th November 1996 and at the Austrian Academy, Vienna, 11th-12th of May 1998, edited by M. Bietak, 39-52. Contributions to the Chronology of the Eastern Mediterranean 1. Vienna: Österreichische Akademie der Wissenschaften.

2000b. "First Beth-Shan Stela, Year 1 (2.4B)." In The Context of Scripture. Vol. 2, Monumental Inscriptions from the Biblical World, edited by W.W. Hallo, 24-5. Leiden: Brill.

Laemmel, S. 2009. "A Note on the Material from the Late Bronze and Early Iron Age Cemeteries of Tel el-Far'ah South." In Forces of Transformation: The End of the Bronze Age in the Mediterranean. Proceedings of an International Symposium Held at St. John's College, University of Oxford 25-6th March, 2006, edited by C. Bachhuber and R.G. Roberts, 170-85. Themes from the Ancient Near East BANEA Publication Series 1. Oxford: Oxbow.

Lehmann, G., S.A. Rosen, A. Berlejung, B.-A. Neumeier, and H.M. Niemann. 2009. "Ausgrabungen in Qubur el-Waleyide, Israel, 2007-2008: Vorbericht.” ZDPV 125(1):1-32.

2010. "Excavations at Qubur al-Walaydah, 20072009.” Der Welt des Orients 40:137-59.

Lichtheim, M. 1976. Ancient Egyptian Literature: The New Kingdom. Berkeley: University of California Press.

Lilyquist, C. 1988. “The Gold Bowl Naming General Djehuty: A Study of Objects and Early Egyptology." MMAJ 23:5-68.

Martin, M.A.S. 2008. "Egyptians at Ashkelon? An Assemblage of Egyptian and Egyptian-Style Pottery.” Ägypten und Levante 18:245-74.

2009. "Egyptian Fingerprints at Late Bronze Age Ashkelon: Egyptian-Style Beer Jars.” In Exploring the Longue Durée: Essays in Honor of Lawrence E. Stager, edited by J.D. Schloen, 297-304. Winona Lake, Ind.: Eisenbrauns.

2011. Egyptian-Type Pottery in the Late Bronze Age Southern Levant. Contributions to the Chronology of the Eastern Mediterranean 29, Denkschriften der Gesamtakademie 69. Vienna: Österreichische Akademie der Wissenschaften.

Mazar, A. 1985. Excavations at Tell Qasile. Vol. 2, The Philistine Sanctuary: Various Finds, the Pottery, Conclusions, Appendixes. Qedem 20. Jerusalem: Institute of Archaeology, Hebrew University of Jerusalem Press. 1990. Archaeology of the Land of the Bible 10,000-586 $B C E$. 1st ed. Edited by D.N. Freedman. Anchor Bible Reference Library. New York: Doubleday.

. 1993. "Qasile, Tel." In The New Encyclopedia of Archaeological Excavations in the Holy Land, edited by E. Stern, 1204-212. Jerusalem: Israel Exploration Society. , ed. 2006. Excavations at Tel Beth-Shean 1989-1996. Vol. 1, From the Late Bronze Age IIB to the Medieval Period. 
Jerusalem: Israel Exploration Society and the Institute of Archaeology, Hebrew University Press.

2007. "Interpretation of the Radiocarbon Dates from

Area R.” In Excavations at Tel Beth-Shean 1989-1996. Vol.

2, The Middle and Late Bronze Age Strata in Area R, edited by A. Mazar and R.A. Mullins, 718-21. Jerusalem: Israel Exploration Society and the Institute of Archaeology, Hebrew University Press.

.2011. "The Egyptian Garrison Town at Beth-Shean." In Egypt, Canaan and Israel: History, Imperialism, Ideology and Literature, edited by S. Bar, D. Kahn, and J.J. Shirley, 155-89. Culture and History of the Ancient Near East 52. Leiden: Brill.

ed. 2012. Excavations at Tel Beth-Shean 1989-1996.

Vol. 4, The Fourth and Third Millennia BCE. Jerusalem: Israel Exploration Society and the Institute of Archaeology, Hebrew University Press.

Mazar, A., and R.A. Mullins, eds. 2007. Excavations at Tel Beth-Shean 1989-1996. Vol. 2, The Middle and Late Bronze Age Strata in Area R. Jerusalem: Israel Exploration Society and the Institute of Archaeology, Hebrew University Press.

Moran, W.L. 1992. The Amarna Letters. Baltimore: Johns Hopkins University Press.

Morris, E.F. 2005. The Architecture of Imperialism: Military Bases and the Evolution of Foreign Policy in Egypt's New Kingdom. Probleme der Ägyptologie 22. Leiden: Brill.

Mullins, R.A. 2006. "A Corpus of Eighteenth Dynasty Egyptian-Style Pottery from Tel Beth-Shean." In "I Will Speak the Riddles of Ancient Times": Archaeological and Historical Studies in Honor of Amihai Mazar on the Occasion of His Sixtieth Birthday, edited by A.M. Maeir and P. de Miroschedji, 247-62. Winona Lake, Ind.: Eisenbrauns.

-2007. “The Late Bronze Age Pottery." In Excavations at Tel Beth-Shean 1989-1996. Vol. 2, The Middle and Late Bronze Age Strata in Area R, edited by A. Mazar and R.A. Mullins, 390-547. Jerusalem: Israel Exploration Society and the Institute of Archaeology, Hebrew University Press.

Nicholson, P.T. 1993. “The Firing of Pottery.” In An Introduction to Egyptian Pottery, edited by D. Arnold and J. Bourriau, 103-20. Mainz: Philipp von Zabern.

Notley, R.S. 2011. "Greco-Roman Jaffa and Its Historical Background." In The History and Archaeology of Jaffa. Vol. 1, edited by M. Peilstöcker and A.A. Burke, 95-107. Jaffa Cultural Heritage Project 1, Monumenta archaeologica 26. Los Angeles: Cotsen Institute of Archaeology.

Oren, E.D. 1987. “The Ways of Horus in North Sinai.” In Egypt, Israel, Sinai: Archaeological and Historical Relationships in the Biblical Period, edited by A.F. Rainey, 69-119. Tel Aviv: Tel Aviv University Press.

_. 1993. "Sera', Tel." In The New Encyclopedia of Archaeological Excavations in the Holy Land, edited by E. Stern, 1329-335. Jerusalem: Israel Exploration Society.

. 1997. "Sera', Tel." In The Oxford Encyclopedia of Archaeology in the Near East, edited by E.M. Meyers, 1-2. New York: Oxford University Press.

_. 2006. “The Establishment of Egyptian Imperial Administration on the 'Ways of Horus': An Archaeological Perspective from North Sinai.” In Timelines: Studies in Honour of Manfred Bietak, edited by E. Czerny, I. Hein, H.
Hunger, D. Melman, and A. Schwab, 279-92. Orientalia Lovaniensia Analecta 149. Leuven: Peeters.

Panitz-Cohen, N. 2014. “The Southern Levant (Cisjordan) During the Late Bronze Age." In The Oxford Handbook of the Archaeology of the Levant (c. 8000-332 BCE), edited by M.L. Steiner and A.E. Killebrew, 541-60. Oxford: Oxford University Press.

Panitz-Cohen, N., and A. Mazar. 2009. Excavations at Tel BethShean 1989-1996. Vol.3, The 13th-11th Century BCE Strata in Areas $N$ and $S$. Jerusalem: Israel Exploration Society and the Institute of Archaeology, Hebrew University Press.

Peilstöcker, M. 2011a. "A Group of Late Bronze Age Tombs from the Ganor Compound." In The History and Archaeology of Jaffa. Vol. 1, edited by M. Peilstöcker and A.A. Burke, 183-86. Jaffa Cultural Heritage Project 1, Monumenta archaeologica 26. Los Angeles: Cotsen Institute of Archaeology.

. 2011b. "The History of Archaeological Research at Jaffa, 1948-2009." In The History and Archaeology of Jaffa. Vol. 1, edited by M. Peilstöcker and A.A. Burke, 17-32. Jaffa Cultural Heritage Project 1, Monumenta archaeologica 26. Los Angeles: Cotsen Institute of Archaeology.

Peilstöcker, M., and A.A. Burke. 2011. "Preliminary Report for the 2007 Ganor Compound Excavations." In The History and Archaeology of Jaffa. Vol. 1, edited by M. Peilstöcker and A.A. Burke, 177-82. Jaffa Cultural Heritage Project 1, Monumenta archaeologica 26. Los Angeles: Cotsen Institute of Archaeology.

Pierce, K.V.L. 2013. "Material Context: The Egyptian and Egyptianized Ceramic Assemblage at Jaffa." In "Living and Dying Abroad: Aspects of Egyptian Cultural Identity in Late Bronze Age and Early Iron Age Canaan," 454-531. Ph.D. diss., University of California, Los Angeles.

Pritchard, J.B., ed. 1969. Ancient Near Eastern Texts Relating to the Old Testament. 3rd ed. Princeton: Princeton University Press.

- 1980. The Cemetery at Tell es-Sa idiyeh, Jordan. University Museum Monograph 41. Philadelphia: University of Pennsylvania Press.

Raban, A. 1985. "The Ancient Harbours of Israel in Biblical Times (from the Neolithic Period to the End of the Iron Age)." In Harbor Archaeology, edited by A. Raban, 11-44. BAR-IS 257. Oxford: Archaeopress.

Re'em, A. 2010. "Yafo, the French Hospital, 2007-2008: Preliminary Report.” Hadashot Arkheologiyot_Excavations and Surveys in Israel 122. www.hadashot-esi.org.il/ report_detail_eng.asp?id=1566\&mag_id=117.

Reeves, N. 1993. “The Ashburnham Ring and the Burial of General Djehuty.” JEA 79:259-61.

Reimer, P.J. et al. 2013. "Intcal13 and Marine13 Radiocarbon Age Calibration Curves 0-50,000 Years Cal BP.” Radiocarbon 55(4):1869-87.

Samuel, D. 2000. "Brewing and Baking." In Ancient Egyptian Materials and Technology, edited by P.T. Nicholson and I. Shaw, 537-77. Cambridge: Cambridge University Press.

Säve-Söderbergh, T. 1957. Four Eighteenth Dynasty Tombs. Private Tombs at Thebes 1. Oxford: Griffith Institute.

Simons, J.J. 1937. Handbook for the Study of Egyptian Topographical Lists Relating to Western Asia. Leiden: Brill. 
Snape, S.R., and P. Wilson. 2007. Zawiyet Umm el-Rakham. Vol. 1, The Temple and Chapels. Bolton, England: Rutherford.

Spalinger, A. 2005. War in Ancient Egypt: The New Kingdom. Ancient World at War. Malden, Mass.: Blackwell.

Stager, L.E. 1995. "The Impact of the Sea Peoples in Canaan (1185-1050 BCE).” In The Archaeology of Society in the Holy Land, edited by T.E. Levy, 332-48. New York: Facts on File.

Strul, L. 2011. "Conservation Projects in Jaffa." In The History and Archaeology of Jaffa. Vol. 1, edited by M. Peilstöcker and A.A. Burke, 41-52. Jaffa Cultural Heritage Project 1, Monumenta archaeologica 26. Los Angeles: Cotsen Institute of Archaeology.

Sweeney, D. 2003. "A Lion-Hunt Scarab and Other Egyptian Objects from the Late Bronze Fortress at Jaffa." TelAviv 30(1):54-65.

Teeter, E., and T.G. Wilfong. 2003. Scarabs, Scaraboids, Seals, and Seal Impressions from Medinet Habu. OIP 118. Chicago: Oriental Institute of the University of Chicago Press.

Toffolo, M., E. Arie, M.A.S. Martin, E. Boaretto, and I. Finkelstein. 2014. "Absolute Chronology of Megiddo, Israel, in the Late Bronze and Iron Ages: High-Resolution Radiocarbon Dating." Radiocarbon 56(1):221-44.

Tubb, J.N. 1988. "Tell es-Sa idiyeh: Preliminary Report on the First Three Seasons of Renewed Excavations." Levant 20:23-88.

- 1990. "Preliminary Report on the Fourth Season of Excavations at Tell es-Sa idiyeh in the Jordan Valley." Levant 22:21-42.

Tubb, J.N., and P.G. Dorrell. 1991. “Tell es-Sa 'idiyeh: Interim Report on the Fifth (1990) Season of Excavations." Levant 23(1):67-86.

_. 1993. “Tell es-Sa 'idiyeh: Interim Report on the Sixth
Season of Excavations.” PEQ 125(1):50-74.

. 1994. "Tell es-Sacidiyeh 1993: Interim Report on the Seventh Season of Excavations." PEQ 126(1):52-67.

Tubb, J.N., P.G. Dorrell, and F.J. Cobbing. 1996. “Interim Report on the Eighth (1995) Season of Excavations at Tell es-Sa idiyeh.” PEQ 128(1):16-40.

- 1997. "Interim Report on the Ninth Season (1996) of Excavations at Tell es-Sa idiyeh, Jordan.” PEQ 129(1): 54-77.

Tufnell, O., and A. Kempinski. 1993. “'Ajjul, Tell el-.” In The New Encyclopedia of Archaeological Excavations in the Holy Land, edited by E. Stern, 49-53. Jerusalem: Israel Exploration Society.

Ussishkin, D. 1995. “The Destruction of Megiddo at the End of the Late Bronze Age and Its Historical Significance." TelAviv 22(2):240-67.

Vogel, C. 2004. Ägyptische Festungen und Garnisonen bis zum Ende des Mittleren Reiches. Hildesheimer Ägyptologische Beiträge 46. Hildesheim, Germany: Gerstenberg.

. 2010. "Storming the Gates? Entrance Protection in the Military Architecture of Middle Kingdom Nubia.” In Cities and Urbanism in Ancient Egypt: Papers from a Workshop in November 2006 at the Austrian Academy of Sciences, edited by M. Bietak, E. Czerny, and I. Forstner-Müller, 299-320. Österreichische Akademie der Wissenschaften 60. Vienna: Österreichische Akademie derWissenschaften. Weinstein, J.M. 1991. "Egypt and the Middle Bronze IIC/ Late Bronze IA Transition in Palestine." Levant 23:105-15.

Weninger, F., P. Steier, W. Kutschera, and E.M. Wild. 2006. “The Principle of the Bayesian Method." Ägypten \& Levante 16:317-24.

Wodzińska, A. 2010. Manual of Egyptian Pottery. Vol. 3, Second Intermediate Period-Late Period. Boston: Ancient Egypt Research Associates. 